WSRC-TR-2000-00249, Rev. 2

\title{
Characterization of Radionuclides in H-Modified and Purex Waste Sludges from H-Area High Level Waste Tanks
}

by

R. F. O'Bryant

Westinghouse Savannah River Company

Savannah River Site

Aiken, South Carolina 29808

W. R. Weiss

This paper was prepared in connection with work done under the above contract number with the $U$. $S$.

Department of Energy. By acceptance of this paper, the publisher and/or recipient acknowledges the U. S.

Government's right to retain a nonexclusive, royalty-free license in and to any copyright covering this paper, along with the right to reproduce and to authorize others to reproduce all or part of the copyrighted paper. 
This document was prepared in conjunction with work accomplished under Contract No. DE-AC09-96SR18500 with the U. S. Department of Energy.

\section{DISCLAIMER}

This report was prepared as an account of work sponsored by an agency of the United States Government. Neither the United States Government nor any agency thereof, nor any of their employees, makes any warranty, express or implied, or assumes any legal liability or responsibility for the accuracy, completeness, or usefulness of any information, apparatus, product or process disclosed, or represents that its use would not infringe privately owned rights. Reference herein to any specific commercial product, process or service by trade name, trademark, manufacturer, or otherwise does not necessarily constitute or imply its endorsement, recommendation, or favoring by the United States Government or any agency thereof. The views and opinions of authors expressed herein do not necessarily state or reflect those of the United States Government or any agency thereof.

This report has been reproduced directly from the best available copy.

Available for sale to the public, in paper, from: U.S. Department of Commerce, National Technical Information Service, 5285 Port Royal Road, Springfield, VA 22161, phone: (800) 553-6847, fax: (703) 605-6900

email: orders@ntis.fedworld.gov

online ordering: http://www.ntis.gov/help/index.asp

Available electronically at http://www.osti.gov/bridge

Available for a processing fee to U.S. Department of Energy and its contractors, in paper, from: U.S. Department of Energy, Office of Scientific and Technical Information, P.O. Box 62, Oak Ridge, TN 37831-0062,

phone: (865)576-8401,

fax: (865)576-5728

email: $\underline{\text { reports@ adonis.osti.gov }}$ 
CHARACTERIZATION OF RADIONUCLIDES IN H-MODIFIED AND PUREX WASTE SLUDGES FROM H-AREA HIGH LEVEL WASTE TANKS (U)
Keywords: Sludge, Waste Characterization, H Tank Farm

Retention: Permanent

\begin{abstract}
Revised By
\end{abstract}
R. F. O'Bryant and W. R. Weiss
Classification: $\mathbf{U}$

Does not Contain UCNI

$\mathrm{ADC} / \mathrm{RO}$

Issued: March 2003

APPROVALS

R. F. O'Bryant, CBU Co-Author

Date:

Date:

W. R. Weiss, DFM for CBU, Co-Author

Date:

L. E. Rykken, DFM for CBU, Technical Reviewer

Date:

M. C. Chandler, CBU Engineering 


\section{TABLE OF CONTENTS}

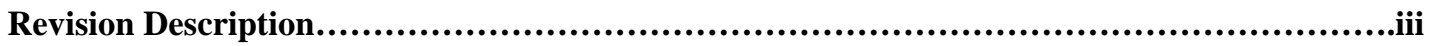

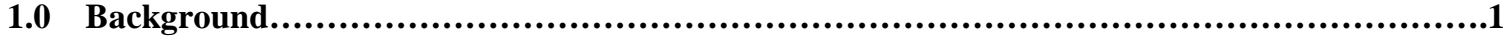

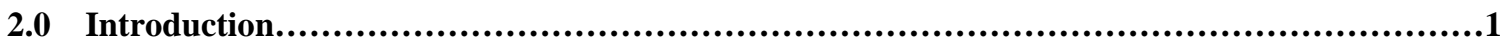

3.0 Development of a Radionuclide Distribution for Sludge Fraction of Sludge-Contaminated

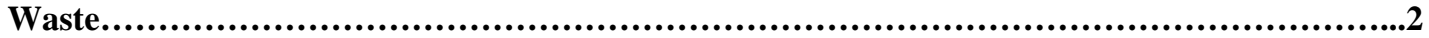

3.1 Determining the Initial List of Radionuclides

3.2 Consolidating Sludge from H-Area Tank Farm

3.3 Excluding Radionuclides from Consideration

3.4 Development of the Sludge Fraction Distribution

3.5 Other WAC Criteria

3.5.1 Comparison to Package Guidelines

3.5.2 Sum-of-Fractions Calculation

3.5.3 Nuclear Criticality Safety Criteria

3.6 Documentation of the Sludge Fraction Distribution

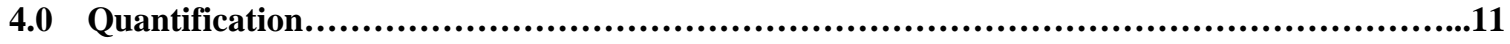

4.1 Quantification of Sludge and Supernate Fractions

4.2 Quantification of Job Control Waste and other Compactable Sludge-Contaminated Waste

4.3 Quantification of Non-Compactable Sludge-Contaminated Waste

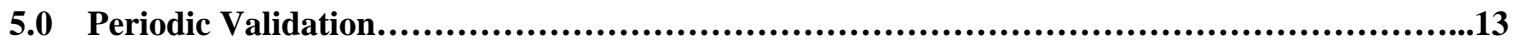

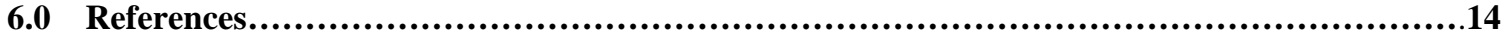


WSRC-TR-2000-00249

Revision 2

\section{ATTACHMENTS}

Attachment 1 'M:IWASTE8\Hlcats|WCSystem\[WCSystem.xls]TankData, Reference Date: 9/11/02, Date Retrieved from WCS: 2/20/03

Attachment 2 'M:IWASTE8\HlcatsIWCSysteml[WCSystem.xls]SludgeInv, Reference Date: 9/11/02, Date Retrieved from WCS: 2/20/03

Attachment 3 Americium/Curium Transfer to Tank 51 Sludge Radionuclide Inventory

Attachment 4 Projected Am/Cm Transfer and Tanks 7 and 18 Combined Contents Transfer to Tank 51

Attachment 5 Calculation of H-Area Tank Farm Scaling Factors from WCS Radionuclide Inventory Data

Attachment 6 Comparison of H-Area Tank Farm Sludge Scaling Factors for Consolidation

Attachment 7 H-Area Tank Farm Sludge Waste Stream Exclusion Criteria

Attachment 8 H-Area Tank Farm Sludge Waste Stream Activity Distribution

Attachment 9 Waste Characterization Form for Sludge Fraction, HTK-00002

Attachment 10 H-Area Tank Farm Sludge Solids Radionuclide Concentrations

Attachment 11 Comparison of H-Area Tank Farm Sludge Solids Waste Against WAC 3.17, Rev. 7, Requirements

\section{LIST OF TABLES}

Table 3.1 Radionuclides Important to Characterization of the Sludge Fraction of H-Area Tank Farm SludgeContaminated Waste

Table 3.2 H-Area Tank Farm Historical Data

Table 3.3 Radionuclides Excluded from Consideration for H-Area Tank Farm Sludge

Table 3.4 Radionuclide Scaling Factors and Distribution for H-Area Tank Farm Sludge

Table 3.5 Comparison of H-Area Tank Farm Sludge-Contaminated Waste to LAWV Limits

Table 3.6 Comparison of H-Area Tank Farm Sludge Waste vs. LAWV Limits and TRU Criteria

Table 3.7 Sum-of-Fractions for Sludge Fraction of H-Area Tank Farm Sludge-Contaminated Waste

Table 3.8 Comparison of H-Area Tank Farm Sludge Waste vs. Sum-of Fraction Limits and TRU Criteria

Table 3.9 Calculation of FGE Equivalent for H-Area Tank Farm Sludge-Contaminated Waste 


\section{Revision Description}

Revision 2 to this document includes the following substantive changes to the Revision 1 document:

- Revalidate H-Area high level waste streams.

- Revise the consolidation of the waste from H-Area high level waste tanks from five waste streams previously documented in three characterization reports [HTK-00002-9, -43, and -30 (WSRC-TR-200000249, this document, previous Revision 1); WPT-00002-51 (WSRC-TR-2000-00115, Revision 1); Reference 5); and HTK-00002-2H42 (WSRC-TR-2001-00132; Reference 6) to one waste stream (HTK00002) in Revision 2 of this document.

- Update the distribution of radionuclides in the consolidated waste stream based on current high level waste tank contents and revised SRS Waste Acceptance Criteria (WAC) 2.02 and 3.17 requirements. 
WSRC-TR-2000-00249

Revision 2

Page 1

\subsection{Background}

Characterization of High Level Waste Sludge by the Savannah River Site Closure Business Unit (CBU) is outlined in WSRC-TR-94-0579, High Level Waste Sludge Characterization in Support of Low Level Waste Certification (Reference 1). The sludge characterization is based on a series of scaling factors for sludgecontaining waste tanks. Scaling Factors were previously compiled and compared with available sample data in WSRC-TR-94-0562, Characterization of Radionuclides in HLW Sludge Based on Isotopic Distribution in Irradiated Assemblies (Reference 2). Quantification of sludge-contaminated waste and application of the scaling factors has been performed on a case-by-case basis since approval of the methodology by the Waste Characterization Board in 1994.

The Waste Characterization System (WCS) was established in 1996 to consolidate waste characterization information. Inventories and compositions of major sludge constituents are based on tank fill histories. Minor constituent inventories are based on compositions developed during DWPF design. Fill histories for each tank are also contained in the WCS (Reference 3). Subsequent analytical data is incorporated into this database as deemed appropriate.

Further examination of historical tank use data contained in Reference 3, tank contents (i.e., high heat or low heat fractions of either Purex or H-Modified waste) and waste age (both in Reference 2) allowed consolidation of sludge in waste tanks to be considered.

WSRC 1S SRS Waste Acceptance Criteria Manual, Procedure 2.02, Low Level, Hazardous, Mixed and PCB Waste Characterization Requirements, Revision 7 (Reference 4), allows for consolidation of waste streams when the following two criteria are met:

1. Performance Assessment (PA) radionuclide scaling factors do not vary from the proposed data set scaling factor by more than a factor of 10 , and

2. The fractional activity of the predominant radionuclides (predominant radionuclides being those that make up 10\% or greater of the activity) in each data set does not vary by more than a factor of 2 from the fractional activity of the same radionuclide in the proposed data set.

This document contains the characterization methodology for sludge-contaminated waste generated from the H-Area Tank Farm, based on process knowledge and available analytical data. In addition, this document contains an evaluation for consolidation of sludge-contaminated waste from multiple high level waste (HLW) tanks in the H-Area Tank Farm. The scaling factors developed in this document supercede those presented in References 1 and 2; the previous revision of the current document [WSRC-TR-200000249, Characterization of Radionuclides in H-Modified and Purex Waste Sludges from H-Area High Level Waste Tanks (U), Revision 1, December 2000] and other previously-developed radionuclide characterizations for H-Area Tank Farm sludge-contaminated waste [WSRC-TR-2000-00115, Characterization of Radionuclides in Waste Sludges from High Level Waste Tanks 40, 42 and 51 (U), Revision 1, August 2000 (Reference 5) and WSRC-TR-2001-00132, Characterization of Radionuclides for $2 H$ Evaporator Cleaning Transfers to Tank 42 (U), Revision 0, March 2001 (Reference 6)].

\subsection{Introduction}

Sludge-contaminated waste consists of waste contaminated with both insoluble species (the sludge fraction) and entrained supernate. The WCS is based on the assumption that, generally, approximately $70-80 \%$ of the volume of what is commonly referred to as sludge is interstitial supernate; the remaining approximately 20-30\% consists of the insoluble species (Reference 1).

Development of a method for characterization of sludge-contaminated waste must consider both fractions. Separate waste cuts may contain sludge and supernate fractions in varying proportions due to the nature of 
the job generating the waste and the variability in waste handling techniques. Development of a distribution representative of all sludge-contaminated waste cuts must allow for varying fractions of sludge and supernate contamination.

This document will develop a radionuclide distribution for the sludge fraction of sludge-contaminated waste stored in all H-Area Tank Farm high level sludge waste tanks in accordance with the methodology outlined in WSRC 1S SRS Waste Acceptance Criteria Manual, Procedure 2.02, Revision 7 (Reference 4). This distribution is based on the assumption that sludge-contaminated waste from all H-Area HLW tanks could be co-mingled, and the actual contamination present on waste in a series of containers from these tanks will be representative of the mean radionuclide distribution. Previously, high level sludge waste from the $\mathrm{H}$ Area Tank Farm has been managed as five separate consolidated waste streams, documented in three separate characterization reports, HTK-00002-9 (Tanks 9, 13, 14), HTK-00002-43 (Tanks 21-23, 43), and HTK-00002-30 (Tanks 11, 12, 15, 30, 32, 35, 36, 39) (this document, previous Revision 1); WPT-0000251 (Tanks 40, 51; Reference 5); and HTK-00002-2H42 (Tank 42; Reference 6). A single, comprehensive characterization for F- and H-Area Tank Farm supernate has been developed previously (Reference 7).

This document also describes the methodology for application of radionuclide distributions representative of sludge-contaminated waste to individual waste packages.

Most of the waste contaminated with sludge from the H-Area Tank Farm will be categorized as low-level waste (LLW) and disposed of in the E-area Vaults (EAV). The waste does, however, have the potential to be categorized as U.S. Department of Energy-defined transuranic waste (TRU) and/or mixed waste (Reference 4). Quantification of hazardous constituents and determination of whether the waste is classified as mixed is dependent on the amount of sludge present on the waste matrix and the nature of the waste matrix, and will be performed on a case-by-case basis. Quantification of radionuclides present in each waste package will be performed as described in Section 4.0.

The radionuclide distribution developed for LLW contaminated with sludge from the F-Area Tank Farm can also be applied to waste classified as TRU waste. [Neither WSRC 1S SRS Waste Acceptance Criteria Manual, Procedure 3.06, E-Area TRU Pads Transuranic Waste Acceptance Criteria, Revision 5, nor Appendix A:34, TRU Waste Container Characterization Form (OSR 29-90) Instruction specifies a methodology for determination of the isotopic distribution in TRU Waste, but simply that the methodology be documented.]

\subsection{Development of a Radionuclide Distribution for Sludge Fraction of Sludge-Contaminated Waste}

The development of the radionuclide distribution in this section is performed per guidance outlined in WSRC 1S SRS Waste Acceptance Criteria Manual, Procedure 2.02, Revision 7 (Reference 4).

\subsection{Determining the Initial List of Radionuclides}

WSRC 1S SRS Waste Acceptance Criteria Manual, Procedure 2.02, Revision 7 (Reference 4), stipulates that the characterization of each package of waste having a total activity greater than 2 nanocuries/gram must consider the potential presence of any radionuclide that meets any one of three criteria:

1. The radionuclide is identified in WSRC 1S SRS Waste Acceptance Criteria Manual, Procedure 3.17, Low Level Waste Acceptance Criteria, Revision 7 (Reference 8), as being a Performance Assessment (PA) or Safety Authorization (SA) Basis radionuclide for a specific treatment, storage or disposal (TSD) facility. For purposes of this distribution, the PA and SA radionuclides for the EAV will be used.

2. The radionuclide could be present in the waste with a relative activity greater than $1.0 \%$ of the total waste stream activity at the time of the characterization. 
WSRC-TR-2000-00249

Revision 2

Page 3

3. The radionuclide is a detectable transuranic or a fissile radionuclide.

The above criteria are hereafter referred to as "inclusion criteria."

Based on the three inclusion criteria and available process knowledge, the following list of 42 radionuclides (Table 3.1) will be considered when developing the radionuclide distribution of waste packages contaminated with sludge from the H-Area Tank Farm.

\begin{tabular}{|c|c|c|c|c|}
\hline \multirow[b]{3}{*}{ Radionuclide } & \multirow{2}{*}{\multicolumn{4}{|c|}{ Inclusion Criteria }} \\
\hline & & & & \\
\hline & $\begin{array}{c}\text { PA } \\
\text { Limiting }\end{array}$ & $\begin{array}{c}\text { SA } \\
\text { Limiting }\end{array}$ & $\begin{array}{c}\text { Potentially Present } \\
\text { At }>1 \% \text { Total Activity }\end{array}$ & $\begin{array}{l}\text { Detectable Fissile or } \\
\text { TRU Radionuclide }\end{array}$ \\
\hline $\mathrm{H}-3$ & & SA & & \\
\hline C-14 & PA & & & \\
\hline $\mathrm{Ni}-59$ & & & $\mathrm{X}$ & \\
\hline Co-60 & & & $\mathrm{X}$ & \\
\hline Ni-63 & & & $\mathrm{X}$ & \\
\hline Se-79 & & & $\mathrm{X}$ & \\
\hline Sr-90 & & & $\mathrm{X}$ & \\
\hline Y-90 & & & Daughter of Sr-90 & \\
\hline Tc-99 & $\mathrm{PA}$ & & & \\
\hline $\mathrm{Ru}-106$ & & & $\mathrm{X}$ & \\
\hline Rh-106 & & & Daughter of Ru-106 & \\
\hline $\mathrm{Sb}-125$ & & & $\mathrm{X}$ & \\
\hline Sn-126 & & & $\mathrm{X}$ & \\
\hline $\mathrm{I}-129$ & $\mathrm{PA}$ & & & \\
\hline Cs-134 & & & $\mathrm{X}$ & \\
\hline Cs-135 & & & $\mathrm{X}$ & \\
\hline Cs-137 & & & $\mathrm{X}$ & \\
\hline Ba-137m & & & Daughter of Cs-137 & \\
\hline Ce-144 & & & $\mathrm{X}$ & \\
\hline Pr-144 & & & Daughter of Ce-144 & \\
\hline Pr-144m & & & Daughter of Ce-144 & \\
\hline $\mathrm{Pm}-147$ & & & $X$ & \\
\hline Eu-154 & & & $\mathrm{X}$ & \\
\hline U-233 & & & & Detectable Fissile \\
\hline U-234 & $\mathrm{PA}$ & & & \\
\hline U-235 & & & & Detectable Fissile \\
\hline U-236 & & & $\mathrm{X}$ & \\
\hline U-238 & PA & & & \\
\hline Np-237 & & & & Detectable TRU \\
\hline Np-239 & & & $X$ & \\
\hline $\mathrm{Pu}-238$ & & & & Detectable TRU \\
\hline $\mathrm{Pu}-239$ & & & & Detectable Fissile, TRU \\
\hline $\mathrm{Pu}-240$ & & & & Detectable TRU \\
\hline $\mathrm{Pu}-241$ & & & & Detectable Fissile \\
\hline $\mathrm{Pu}-242$ & & & & Detectable TRU \\
\hline Am-241 & & & & Detectable TRU \\
\hline Am-242m & & & & Detectable Fissile, TRU \\
\hline Am-243 & & & & Detectable TRU \\
\hline $\mathrm{Cm}-244$ & & & $\mathrm{X}$ & \\
\hline $\mathrm{Cm}-245$ & & & & Detectable Fissile, TRU \\
\hline $\mathrm{Cm}-246$ & & & & Detectable TRU \\
\hline $\mathrm{Cm}-247$ & & & & Detectable Fissile, TRU \\
\hline
\end{tabular}


WSRC-TR-2000-00249

Revision 2

Page 4

\subsection{Consolidating Sludge from H-Area Tank Farm}

WSRC 1S SRS Waste Acceptance Criteria Manual, Procedure 2.02, Revision 7 (Reference 4), allows for consolidation of waste streams when the following two criteria are met:

1. Performance Assessment radionuclide scaling factors do not vary from the proposed data set scaling factor by more than a factor of 10 , and

2. The fractional activity of the predominant radionuclides (predominant radionuclides being those that make up $10 \%$ or greater of the activity) in each data set does not vary by more than a factor of 2 from the fractional activity of the same radionuclide in the proposed data set.

Historical data for active tanks under consideration for consolidation are reproduced in Table 3.2.

\begin{tabular}{|c|c|c|c|c|c|l|}
\hline \multicolumn{7}{|c|}{ Table 3.2. H-Area Tank Farm Historical Data } \\
\hline $\begin{array}{c}\text { Tank } \\
\text { No. }\end{array}$ & $\begin{array}{c}\text { M H- } \\
\text { Modified } \\
\text { HHW }\end{array}$ & $\begin{array}{c}\text { \% H- } \\
\text { Modified } \\
\text { LHW }\end{array}$ & $\begin{array}{c}\% \\
\text { Purex } \\
\text { HHW }\end{array}$ & $\begin{array}{c}\text { Purex } \\
\text { LHW }\end{array}$ & $\begin{array}{c}\text { Yr. of } \\
\text { Waste } \\
\text { Rcpt. }\end{array}$ & \multicolumn{1}{|l|}{ Tank Use/Notes } \\
\hline 9 & & & 50 & 50 & 1955 & Waste Removal \\
\hline 10 & 1 & 1 & 49 & 49 & $56-59$ & Waste Removal \\
\hline 11 & 68 & 17 & & 15 & $56-59$ & Waste Removal \\
\hline 12 & 84 & & 8 & 8 & $56-73$ & Waste Removal \\
\hline 13 & 1 & 88 & & 11 & $56-74$ & Waste Removal \\
\hline 14 & 16 & 25 & 59 & & $57-65$ & Waste Removal \\
\hline 15 & 92 & 8 & & & $60-81$ & Waste Removal \\
\hline 21 & & 100 & & & $76-81$ & Evaporator Feed from RBOF/RRF, DWPF \\
\hline 22 & & 100 & & & $74-84$ & Evaporator Feed from DWPF/HDB8 \\
\hline 23 & & & & & 84 & Evaporator Feed from RBOF/RRF \\
\hline 30 & 100 & & & & 86 & Concentrate Receipt Tank \\
\hline 32 & 91 & 9 & & & $71-88$ & Evaporator Feed from Canyon \\
\hline 35 & 100 & & & & $77-90$ & Evaporator Feed from Canyon \\
\hline 36 & 100 & & & & 78 & Concentrate Receipt Tank \\
\hline 39 & 100 & & & & $82-91$ & Evaporator Feed from Canyon \\
\hline 40 & & & & & & Extended Sludge Processing \\
\hline 42 & & & & & & Extended Sludge Processing \\
\hline 43 & & 100 & & & $82-86$ & Evaporator Feed from RBOF/RRF/DWPF/HDB8 \\
\hline 51 & & & & & & Extended Sludge Processing \\
\hline
\end{tabular}

The tanks contain H-Modified Waste and/or Purex Waste (both high- and low-heat) in varying proportions. The waste is aged from 12-48 years. The tanks are all utilized for either waste removal, concentrate receipt, evaporator feed, or extended sludge processing.

The WCS contains significant process knowledge supplemented with analytical data relating to what is present in the sludge fraction of these waste tanks. The WCS was accessed for the current distribution of radionuclides in the tanks to determine activities, concentrations, and scaling factors (to Sr-90) for the tank sludge fractions (References 9 and 10; Attachments 1 and 2).

Inventories of radionuclides known to be present in HLW tanks in the H-Area Tank Farm were determined from decay-corrected activity data tables in the WCS (Attachments 1 and 2). Consolidated waste stream averages for radionuclide activity and concentration data and resultant scaling factors are conservatively calculated to include only those tanks in the consolidation that contained the particular radionuclide; i.e., zero activities were not included in the averages. 
The WCS is periodically updated to account for waste transfers to and from HLW tanks. In conducting this revalidation, it was determined that the most recent WCS update, which was accessed to obtain current tank contents status (Attachments 1 and 2; References 9 and 10), did not include the transfer of 30,000 gallons of americium/curium $(\mathrm{Am} / \mathrm{Cm})$ solution (estimated 6,000 gallons sludge solids; Attachment 3) from F-Canyon Tank 17.1 to H-Area HLW Tank 51, which has occurred (Reference 11). Also, the most recent WCS update did not include the transfer of the combined contents (estimated total of 256,000 gallons of sludge slurry including an estimated total of 76,800 gallons of sludge solids; Attachments 1 and 4) of F-Area HLW Tanks 7 and 18 (Reference 12), which are planned for tank closure, to H-Area HLW Tank 51. In order to include these significant transfers within the consolidated H-Area Tank Farm sludge waste stream, the projected radionuclide inventories for the Am/Cm solution sludge (Reference 11; Attachments 3 and 4) and the combined Tank 7 and 18 sludge (Reference 12, Attachments 1and 4) transfers were obtained and added to the WCS Tank 51 data retrieved on February 20, 2003, to determine projected radionuclide activities (Ci) after the transfer had occurred (Attachments 4 and 5). From the projected final radionuclide inventories for Tank 51 and the other H-Area high level waste tanks, average H-Area Tank Farm radionuclide activities and scaling factors were calculated (Attachment 5).

The set of isotope activities representative of each H-Area tank per the methodology above were next compared to each other to determine whether sludge-contaminated waste from these tanks met the two WAC criteria for consolidation (Attachment 6).

First, the arithmetic mean activity for each isotope under consideration was calculated. The scaling factors (to Sr-90) for PA radionuclides for each waste tank were then compared to determine whether they were within a factor of 10 from the proposed data set, i.e., the arithmetic mean set of scaling factors for the single, consolidated waste stream (Attachment 6).

The second criterion applies to predominant radionuclides only. There are two predominant radionuclides in this distribution, Sr-90 and its daughter Y-90. The fractional activities of Sr-90 and Y-90 were compared to determine whether they were within a factor of 2 from the proposed data set, the arithmetic mean set of fractional activities for the consolidated waste stream. This is also documented in Attachment 6.

Specific issues related to quantification of sludge-contaminated waste generated from these tanks are contained in Section 4. Analysis of combined waste stream HTK-00002 is documented in Attachment 6 and summarized below.

In order to meet the first consolidation criteria, the scaling factors of the PA radionuclides must be present within one order of magnitude from the mean, or within a range of 0.1 to 10 times the mean scaling factor for the waste stream.

Scaling factors for waste stream HTK-00002 were within consolidation criteria set forth in WAC 2.02, Revision 7 (Reference 4) with the following exceptions (Attachment 6):

The PA radionuclides C-14, Tc-99, I-129, U-234, and U-238, are present in some H-Area high level sludge waste tanks, while not in others. In addition, some tanks contain 1-3 orders of magnitude less C-14 or U238 than the factor of $10 \mathrm{WAC}$ consolidation criterion, compared with the average stream. The WSRC 1S SRS Waste Acceptance Criteria Manual, Procedure 2.02, Revision 7 (Reference 4), indicates that "these [consolidation] factors can be exceeded if it can be shown that the distribution used will be conservative, i.e., the reported activity will be greater than if the factors were within the guidelines." In the case of those tanks in which the PA radionuclides are not present, the combined waste stream scaling factors are based upon an average of scaling factors for the tanks containing the radionuclides, and applied to waste generated from all the tanks in this grouping. In the case of those tanks containing C-14 and/or U-238 at concentration levels that cause the scaling factors to be less than 0.1 times the mean scaling factors for the waste stream, the mean scaling factor to be applied for H-Area high level sludge waste for that radionuclide would meet the exception clause of WAC 2.02 stated above, “...that the distribution used will be conservative...." 
WSRC-TR-2000-00249

Revision 2

Page 6

A single H-Area high level sludge waste tank, Tank 51, contains a concentration of the PA radionuclide I-129 that results in the scaling factor for this radionuclide to be more than a factor of 10 greater than the mean scaling factor. In this case, the mean scaling factor for this radionuclide was recalculated and reanalyzed after including only those tanks in which I-129 had higher relative concentrations; this recalculation of a higher mean scaling factor resulted in the scaling factor for I-129 to be within the factor of 10 consolidation criterion.

The second consolidation criterion applies to predominant radionuclides. There are two predominant ( $>10 \%$ of total activity) radionuclides in H-Area high level sludge waste, Sr-90 and its daughter Y-90. The fractional activities of Sr-90 and Y-90 (Attachment 6) vary only slightly within the distribution of sludge; the maximum variation $(9.5 \%)$ from the proposed data set (the mean distribution) is well within a factor of 2 , the second criteria for consolidation.

The recalculated mean set of scaling factors are compared against the individual tank values in Attachment 6. Based on the results of this final comparison, both consolidation criteria are met for the single, combined waste stream HTK-00002 and, therefore, the sludge fraction of sludge-contaminated waste from all the HArea tanks (listed in Table 3.3) may be consolidated. Accordingly, the recalculated arithmetic mean scaling factor for I-129 will be used in the remainder of the development of the radionuclide distribution.

\subsection{Excluding Radionuclides from Consideration}

Under WSRC 1S SRS Waste Acceptance Criteria Manual, Procedure 2.02, Revision 7 (Reference 4), radionuclides that meet one of the inclusion criteria outlined in section 3.1 may be excluded from further consideration for a waste stream if one or more of the following conditions exist:

1. There is no reason to expect the radionuclide to be present in the waste stream.

2. For non-SA or non-PA radionuclides, or non-detectable fissile or TRU radionuclides, the individual activity contribution is less than $1.0 \%$ of the total radionuclide activity.

The above criteria are hereafter referred to as "exclusion criteria;" exclusion results are presented in Attachment 7 and Table 3.3.

(Note: WSRC 1S SRS Waste Acceptance Criteria Manual, Procedure WAC 2.02, Revision 7, also allows for exclusion from the waste stream distribution of radionuclides whose activities are below specific analytical laboratory Maximum Allowable Lower Limits of Detection [MALLDs]. For conservatism, this exclusion criterion will not be used for this process-knowledge-based characterization of sludge waste stream HTK-00002).

Of the 42 radionuclides listed in Table 3.1, one SA radionuclide (H-3) is excluded because it is not expected to be present in consolidated waste stream HTK-00002 (Table 3.3; Attachment 7). Of the radionuclides included because they were expected to be present at more than $1 \%$ of total activity, 18 are determined to be present at less than $1 \%$ of the total activity in the waste stream. Four of these radionuclides (Co-60, Pm-147, Eu-154, and Cm-244), however, are retained in the distribution since they are near $1 \%$ of total activity. 
WSRC-TR-2000-00249

Revision 2

Page 7

\begin{tabular}{|c|c|c|}
\hline \multicolumn{3}{|c|}{$\begin{array}{l}\text { Table 3.3. Radionuclides Excluded from } \\
\text { Consideration for H-Area Tank Farm Sludge }\end{array}$} \\
\hline & \multicolumn{2}{|c|}{ Exclusion Criteria } \\
\hline & Not Expected & $\begin{array}{l}\text { Present at }<1 \% \\
\text { (a) }\end{array}$ \\
\hline H-3 & $\mathrm{X}$ & \\
\hline \multicolumn{3}{|l|}{ C-14 } \\
\hline Ni-59 & & $\mathrm{X}$ \\
\hline Co-60 & & $\mathrm{X}(\mathrm{b})$ \\
\hline Ni-63 & & $\mathrm{X}$ \\
\hline Se-79 & & $\mathrm{X}$ \\
\hline \multicolumn{3}{|l|}{ Sr-90 } \\
\hline \multicolumn{3}{|l|}{ Y-90 } \\
\hline \multicolumn{3}{|l|}{ Tc-99 } \\
\hline Ru-106 & & $X$ \\
\hline Rh-106 & & $\mathrm{X}$ \\
\hline Sb-125 & & $\mathrm{X}$ \\
\hline Sn-126 & & $\mathrm{X}$ \\
\hline \multicolumn{3}{|l|}{ I-129 } \\
\hline Cs-134 & & $\mathrm{X}$ \\
\hline Cs-135 & & $\mathrm{X}$ \\
\hline \multicolumn{3}{|l|}{ Cs-137 } \\
\hline \multicolumn{3}{|l|}{ Ba-137m } \\
\hline Ce-144 & & $\mathrm{X}$ \\
\hline Pr-144 & & $\mathrm{X}$ \\
\hline Pr-144m & & $\mathrm{X}$ \\
\hline Pm-147 & & $X(b)$ \\
\hline Eu-154 & & $\mathrm{X}(\mathrm{b})$ \\
\hline \multicolumn{3}{|l|}{ U-233 } \\
\hline \multicolumn{3}{|l|}{ U-234 } \\
\hline \multicolumn{3}{|l|}{ U-235 } \\
\hline U-236 & & $\mathrm{X}$ \\
\hline \multicolumn{3}{|l|}{ U-238 } \\
\hline \multicolumn{3}{|l|}{ Np-237 } \\
\hline Np-239 & & $\mathrm{X}$ \\
\hline \multicolumn{3}{|l|}{$\mathrm{Pu}-238$} \\
\hline \multicolumn{3}{|l|}{$\mathrm{Pu}-239$} \\
\hline \multicolumn{3}{|l|}{ Pu-240 } \\
\hline \multicolumn{3}{|l|}{$\mathrm{Pu}-241$} \\
\hline \multicolumn{3}{|l|}{$\mathrm{Pu}-242$} \\
\hline \multicolumn{3}{|l|}{ Am-241 } \\
\hline \multicolumn{3}{|l|}{$\mathrm{Am}-242 \mathrm{~m}$} \\
\hline \multicolumn{3}{|l|}{ Am-243 } \\
\hline Cm-244 & & $\mathrm{X}(\mathrm{b})$ \\
\hline \multicolumn{3}{|l|}{$\mathrm{Cm}-245$} \\
\hline \multicolumn{3}{|l|}{$\mathrm{Cm}-246$} \\
\hline Cm-247 & & \\
\hline
\end{tabular}

(a) For those radionuclides included only because they were expected to be present at $>1 \%$

(b) Retained in distribution since they are close to $1 \%$ total activity

NOTE: Bold $=$ PA/SA radionuclides 
WSRC-TR-2000-00249

Revision 2

Page 8

\subsection{Development of the Sludge Fraction Distribution}

Forty-two radionuclides were determined to be important to characterization of the sludge in H-Area Tank Farm. A number of these have been excluded per discussion in Section 3.3, leaving 27 radionuclides to be quantified for consolidated waste stream HTK-00002. Current tank curie contents were used to update the scaling factors to create an isotopic distribution for the single, consolidated waste stream. The radionuclides, corresponding scaling factors (to $\mathrm{Sr}-90$ ), and mean activity distribution in the waste stream are summarized in Attachments 8 and 9, and Table 3.4.

\begin{tabular}{|c|c|c|}
\hline \multicolumn{3}{|c|}{$\begin{array}{l}\text { Table 3.4. Mean Radionuclide Scaling Factors and } \\
\text { Distribution for H-Area Tank Farm Sludge }\end{array}$} \\
\hline Radionuclide & $\begin{array}{l}\text { Mean Scaling } \\
\text { Factors } \\
(\mathrm{Ci} / \mathrm{Ci} \mathrm{Sr}-90)^{\mathrm{a}}\end{array}$ & $\begin{array}{c}\text { Mean } \\
\text { Distribution, } \\
\text { Normalized }^{\mathrm{a}} \\
(\%)\end{array}$ \\
\hline C-14 & $5.73 \mathrm{E}-08$ & $2.61 \mathrm{E}-06$ \\
\hline Co-60 & $3.46 \mathrm{E}-03$ & $1.58 \mathrm{E}-01$ \\
\hline Sr-90 & $1.00 \mathrm{E}+00$ & $4.55 \mathrm{E}+01$ \\
\hline Y-90 & $1.00 \mathrm{E}+00$ & $4.55 \mathrm{E}+01$ \\
\hline Tc-99 & $3.19 \mathrm{E}-04$ & $1.45 \mathrm{E}-02$ \\
\hline I-129 & $3.51 \mathrm{E}-09$ & $1.59 \mathrm{E}-07$ \\
\hline Cs-137 & $5.87 \mathrm{E}-02$ & $2.67 \mathrm{E}+00$ \\
\hline Ba-137m & $5.55 \mathrm{E}-02$ & $2.52 \mathrm{E}+00$ \\
\hline Pm-147 & $1.94 \mathrm{E}-02$ & $8.81 \mathrm{E}-01$ \\
\hline Eu-154 & $1.13 \mathrm{E}-02$ & $5.14 \mathrm{E}-01$ \\
\hline U-233 & $3.04 \mathrm{E}-06$ & $1.38 \mathrm{E}-04$ \\
\hline U-234 & $1.13 \mathrm{E}-06$ & $5.13 \mathrm{E}-05$ \\
\hline $\mathrm{U}-235$ & $2.52 \mathrm{E}-08$ & $1.15 \mathrm{E}-06$ \\
\hline U-238 & $3.97 \mathrm{E}-07$ & $1.80 \mathrm{E}-05$ \\
\hline $\mathrm{Np}-237$ & $1.49 \mathrm{E}-06$ & $6.79 \mathrm{E}-05$ \\
\hline $\mathrm{Pu}-238$ & $3.13 \mathrm{E}-02$ & $1.42 \mathrm{E}+00$ \\
\hline $\mathrm{Pu}-239$ & $4.68 \mathrm{E}-04$ & $2.13 \mathrm{E}-02$ \\
\hline $\mathrm{Pu}-240$ & $2.12 \mathrm{E}-04$ & $9.65 \mathrm{E}-03$ \\
\hline $\mathrm{Pu}-241$ & $1.35 \mathrm{E}-02$ & $6.15 \mathrm{E}-01$ \\
\hline $\mathrm{Pu}-242$ & $6.49 \mathrm{E}-07$ & $2.95 \mathrm{E}-05$ \\
\hline Am-241 & $2.28 \mathrm{E}-04$ & $1.03 \mathrm{E}-02$ \\
\hline Am-242m & $9.08 \mathrm{E}-06$ & $4.13 \mathrm{E}-04$ \\
\hline Am-243 & $5.15 \mathrm{E}-04$ & $2.34 \mathrm{E}-02$ \\
\hline $\mathrm{Cm}-244$ & $3.60 \mathrm{E}-03$ & $1.64 \mathrm{E}-01$ \\
\hline $\mathrm{Cm}-245$ & $3.61 \mathrm{E}-07$ & $1.64 \mathrm{E}-05$ \\
\hline $\mathrm{Cm}-246$ & $7.05 \mathrm{E}-06$ & $3.21 \mathrm{E}-04$ \\
\hline $\mathrm{Cm}-247$ & $3.44 \mathrm{E}-11$ & $1.57 \mathrm{E}-09$ \\
\hline Total & $2.20 \mathrm{E}+00$ & $1.00 \mathrm{E}+02$ \\
\hline
\end{tabular}

${ }^{\mathrm{a} A t t a c h m e n t s} 7$ and 8 . 
WSRC-TR-2000-00249

Revision 2

Page 9

\subsection{Other WAC Criteria}

\subsubsection{Comparison to Package Guidelines}

Most sludge-contaminated waste will be disposed of in the E-Area Vaults (EAV). Administrative Waste Package Radiological Concentration Guidelines apply to waste disposed of in the EAV. The guidelines applicable to the Low Activity Waste Vault (LAWV), that portion of the EAV reserved for low activity waste, will be used for comparison since they are the most restrictive of the EAV facilities. Low activity waste is defined as waste that will produce less than or equal to $200 \mathrm{mR} / \mathrm{hr}$ at $5 \mathrm{~cm}$ from an unshielded final disposal container. The average concentration (Ci/gallon of sludge solids; see note below) of each radionuclide in the H-Area Tank Farm Sludge Waste Stream (Attachment 10) and their corresponding LAWV limits (Reference 8) are compared in Table 3.5. Calculations supporting this comparison are in Attachment 11. LAWV limits are expressed in $\mathrm{Ci} / \mathrm{ft}^{3}$ waste and $\mathrm{Ci} / 90 \mathrm{ft}^{3} \mathrm{~B}-25$ container.

[Note: The gallons of sludge solids identified in this section and in Tables 3.5 to 3.9 are the measured gallons of sludge in HLW tanks less the interstitial supernate (generally 70 volume percent) as recorded in the WCS.]

\begin{tabular}{|c|c|c|c|c|}
\hline \multicolumn{5}{|c|}{$\begin{array}{c}\text { Table 3.5. Comparison of H-Area Tank Farm Sludge- } \\
\text { Contaminated Waste to LAWV Limits }\end{array}$} \\
\hline Radionuclide & $\begin{array}{c}\text { Average } \\
\text { Concentration } \\
\text { in } \\
\text { Sludge solids } \\
\text { (Ci/gal) }\end{array}$ & $\begin{array}{c}\text { LAWV Limit } \\
\left(\mathbf{C i} / \mathbf{f t}^{\mathbf{3}}\right)\end{array}$ & $\begin{array}{c}\text { LAWV limit } \\
(\mathbf{C i} / \mathbf{B}-25)\end{array}$ & $\begin{array}{c}\text { Gallons of } \\
\text { sludge solids in } \\
\text { B-25 to reach } \\
\text { LAWV limit }\end{array}$ \\
\hline & A & B & C=B*90 ft3/B-25 & D=C/A \\
\hline H-3 & & $1.10 \mathrm{E}+01$ & $9.90 \mathrm{E}+02$ & \\
\hline $\mathrm{C}-14$ & $4.40 \mathrm{E}-06$ & $2.50 \mathrm{E}-05$ & $2.25 \mathrm{E}-03$ & $5.11 \mathrm{E}+02$ \\
\hline Tc-99 & $3.27 \mathrm{E}-02$ & $5.60 \mathrm{E}-05$ & $5.04 \mathrm{E}-03$ & $\mathbf{1 . 5 4 E - 0 1}$ \\
\hline I-129 & $1.65 \mathrm{E}-07$ & $1.10 \mathrm{E}-08$ & $9.90 \mathrm{E}-07$ & $6.00 \mathrm{E}+00$ \\
\hline $\mathrm{U}-234$ & $9.31 \mathrm{E}-05$ & $1.10 \mathrm{E}-03$ & $9.90 \mathrm{E}-02$ & $1.06 \mathrm{E}+03$ \\
\hline $\mathrm{U}-238$ & $1.31 \mathrm{E}-05$ & $1.20 \mathrm{E}-03$ & $1.08 \mathrm{E}-01$ & $8.24 \mathrm{E}+03$ \\
\hline
\end{tabular}

From the container limits, the maximum volume of sludge solids that could be present in a B-25 container while still meeting the LAWV limits can be calculated. The most limiting isotope in waste stream HTK00002 is Tc-99, for which more than 0.15 gallon of sludge solids in a B-25 would cause the waste to exceed the LAWV limit. Sludge solids in the H-Area Tank Farms has an average total activity of $280 \mathrm{Ci} / \mathrm{gallon}$ and an average total transuranic isotope activity of $6.4 \mathrm{Ci} /$ gallon. Accordingly, 0.15 gallon of sludge solids to meet the LAWV limit for Tc-99 would be equivalent to 43.1 total $\mathrm{Ci}$ in a $\mathrm{B}-25,1 \mathrm{Ci}$ of which is the transuranic component. Per Table 3.6 for HTK-00002, the limiting amount of sludge solids would be equivalent to an amount ( $436 \mathrm{nCi} / \mathrm{g})$ that would exceed the TRU limit of $100 \mathrm{nCi} / \mathrm{g}$ and, therefore, would not be disposed of in the LAWV. In practice, very few waste boxes fail TRU limits. Any such box will, upon entry into WITS, be flagged as TRU and not be sent to the LAWV. 


\begin{tabular}{|c|c|c|c|c|c|c|}
\hline \multicolumn{7}{|c|}{ Table 3.6. Comparison of H-Area Tank Farm Sludge Waste vs. LAWV Limits and TRU Criteria } \\
\hline $\begin{array}{c}\text { Maximum } \\
\text { gallons of } \\
\text { sludge } \\
\text { solids/ B-25 } \\
\text { to meet } \\
\text { LAWV } \\
\text { criteria } \\
\end{array}$ & $\begin{array}{c}\text { Average } \\
\text { total Ci / } \\
\text { gallon } \\
\text { sludge } \\
\text { solids }\end{array}$ & $\begin{array}{c}\text { Average } \\
\text { total Ci / } \\
\text { B-25 at } \\
\text { LAWV } \\
\text { limit }\end{array}$ & 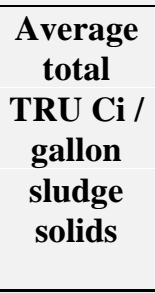 & $\begin{array}{c}\text { Average } \\
\text { total TRU } \\
\text { Ci / } \\
\text { B-25 at } \\
\text { LAWV } \\
\text { limit }\end{array}$ & $\begin{array}{c}\text { TRU nCi/g } \\
\text { at maximum } \\
\text { waste weight } \\
(5000 \mathrm{lb}) \\
\text { in a B-25 at } \\
\text { LAWV limit }\end{array}$ & $\begin{array}{c}\text { Minimum waste } \\
\text { weight in a B-25 at } \\
\text { LAWV limit to not } \\
\text { be TRU waste } \\
\text { (lb) }\end{array}$ \\
\hline $\mathrm{A}$ & B & $\mathrm{C}=\mathrm{A} * \mathrm{~B}$ & $\mathrm{D}$ & $\mathrm{E}=(\mathrm{D} / \mathrm{B}) * \mathrm{C}$ & $\begin{array}{c}=\left(\mathrm{E}^{*} 1 \mathrm{E}+09 \mathrm{nCi} / \mathrm{Ci}\right) / \\
(5000 \mathrm{lb} * 454 \mathrm{~g} / \mathrm{lb})\end{array}$ & $\begin{array}{l}=\left(\mathrm{E}^{*} 1 \mathrm{E}+09 \mathrm{nCi} / \mathrm{Ci}\right) / \\
(454 \mathrm{~g} / \mathrm{lb} * 100 \mathrm{nCi} / \mathrm{g})\end{array}$ \\
\hline $1.54 \mathrm{E}-01$ & $2.80 \mathrm{E}+02$ & $4.31 \mathrm{E}+01$ & $6.43 \mathrm{E}+00$ & $9.90 \mathrm{E}-01$ & 4.36E+02 & $2.18 \mathrm{E}+04$ \\
\hline
\end{tabular}

Note: Average total activity of sludge solids from Attachments 10 and $11=2.80 \mathrm{E}+02 \mathrm{Ci} / \mathrm{gal}$.

Average total TRU activity of sludge solids from Attachments 10 and $11=6.43 \mathrm{E}+00 \mathrm{Ci} / \mathrm{gal}$.

\subsubsection{Sum-of-Fractions Calculation}

For acceptance of waste packages sent to the LAWV, the radiological content of the waste package must be compared to the administrative guidelines and shown to satisfy the sum-of-fractions criteria where:

activity concentration of isotope $\mathrm{A} /$ limit of isotope $\mathrm{A}$

+ activity concentration of isotope $\mathrm{B} /$ limit of isotope $\mathrm{B}$

+ activity concentration of isotope $\mathrm{N} /$ limit of isotope $\mathrm{N}$

$\leq 1$

Attachment 11 and Table 3.7 calculate the maximum concentration of sludge solids on sludge-contaminated waste in order for the sum-of-the-fractions criteria to be met.

\begin{tabular}{|c|c|c|c|c|c|c|}
\hline \multicolumn{7}{|c|}{ Table 3.7. Sum-of-Fractions for H-Area Tank Farm Sludge-Contaminated Waste } \\
\hline Radionuclide & $\begin{array}{l}\text { Ci/gal } \\
\text { sludge } \\
\text { solids }\end{array}$ & $\begin{array}{c}\mathrm{Ci} / \mathrm{ft}^{3} \\
\text { sludge } \\
\text { solids }\end{array}$ & $\begin{array}{c}\mathbf{f t}^{3} \text { sludge } \\
\text { solids / } \mathbf{f t}^{3} \\
\text { waste }\end{array}$ & $\begin{array}{l}\mathrm{Ci} / \mathrm{ft}^{3} \\
\text { waste }\end{array}$ & $\begin{array}{l}\text { LAWV limit } \\
\left(\mathbf{C i} / \mathbf{f t}^{3}\right)\end{array}$ & Fraction \\
\hline & A & $\mathrm{B}=\mathrm{A} * 7.48$ & $\mathrm{C}$ & $\mathrm{D}=\mathrm{B} * \mathrm{C}$ & $\mathrm{E}$ & $=\mathrm{D} / \mathrm{E}$ \\
\hline H-3 & & & & & $1.10 \mathrm{E}+01$ & \\
\hline $\mathrm{C}-14$ & $4.40 \mathrm{E}-06$ & $3.29 \mathrm{E}-05$ & 2.23E-04 & $7.33 \mathrm{E}-09$ & $2.50 \mathrm{E}-05$ & $2.93 \mathrm{E}-04$ \\
\hline Tc-99 & $3.27 \mathrm{E}-02$ & $2.45 \mathrm{E}-01$ & 2.23E-04 & $5.45 \mathrm{E}-05$ & $5.60 \mathrm{E}-05$ & 9.74E-01 \\
\hline I-129 & $1.65 \mathrm{E}-07$ & $1.23 \mathrm{E}-06$ & 2.23E-04 & $2.75 \mathrm{E}-10$ & $1.10 \mathrm{E}-08$ & $2.50 \mathrm{E}-02$ \\
\hline U-234 & $9.31 \mathrm{E}-05$ & $6.96 \mathrm{E}-04$ & 2.23E-04 & $1.55 \mathrm{E}-07$ & $1.10 \mathrm{E}-03$ & $1.41 \mathrm{E}-04$ \\
\hline U-238 & $1.31 \mathrm{E}-05$ & $9.80 \mathrm{E}-05$ & 2.23E-04 & $2.18 \mathrm{E}-08$ & $1.20 \mathrm{E}-03$ & $1.82 \mathrm{E}-05$ \\
\hline & & & & \multicolumn{2}{|c|}{ Sum-of-Fractions } & 9.99E-01 \\
\hline
\end{tabular}

Tc-99 dominates the sum-of-the-fractions for sludge waste stream HTK-00002. Primarily based on this dominance, the sum-of-fractions criteria are met for a maximum of $2.23 \mathrm{E}-04 \mathrm{ft}^{3}$ of sludge solids (Table 3.7) for each $1 \mathrm{ft}^{3}$ of waste, which equates to $2.00 \mathrm{E}-02 \mathrm{ft}^{3}\left(2.23 \mathrm{E}-04 \mathrm{ft}^{3}\right.$ sludge solids $/ \mathrm{ft}^{3}$ waste $\mathrm{x} 90 \mathrm{ft}^{3}$ maximum waste volume per B-25) or 1.50E-01 gallon of sludge solids per $90 \mathrm{ft}^{3}$ volume B-25 container (Attachment 11 and Table 3.8). Since the mean total activity and the mean total transuranic activity for sludge solids are, respectively, $280 \mathrm{Ci} / \mathrm{gal}$ and $6.43 \mathrm{Ci} / \mathrm{gal}$, this is equivalent to $42 \mathrm{total} \mathrm{Ci}$ of sludge solids in a B-25, or 9.71E-01 Ci of transuranic isotopes in a B-25 for this waste stream. Any B-25 waste container containing $9.65 \mathrm{E}-01 \mathrm{Ci}$ (or $9.65 \mathrm{E}+08 \mathrm{nCi}$ ) of transuranics must contain $9.65 \mathrm{E}+06 \mathrm{~g}$ (or $2.13 \mathrm{E}+04 \mathrm{lbs}$ ) or more of waste (compared to the $5000 \mathrm{lb}$ maximum waste weight per B-25 container) in order to be within 
the TRU limit of $100 \mathrm{nCi} / \mathrm{g}$ total transuranics. So, for HTK-00002, the sum-of-fractions limiting amount of sludge solids would be equivalent to an amount that would exceed by more than four times $(425 \mathrm{nCi} / \mathrm{g})$ the TRU limit of $100 \mathrm{nCi} / \mathrm{g}$ and would not be disposed of in the LAWV. In practice, very few waste boxes fail TRU limits. Any such box will, upon entry into WITS, be flagged as TRU and not be sent to the LAWV.

\begin{tabular}{|c|c|c|c|c|c|}
\hline \multicolumn{6}{|c|}{$\begin{array}{l}\text { Table 3.8. Comparison of H-Area Tank Farm Sludge Waste vs. } \\
\text { LAWV Sum-of-Fractions Limits and TRU Criteria }\end{array}$} \\
\hline $\begin{array}{c}\text { Maximum } \mathrm{ft}^{3} \\
\text { sludge solids } \\
\text { per } \mathrm{ft}^{3} \text { waste } \\
\text { to meet sum- } \\
\text { of-fractions } \\
\text { criteria }\end{array}$ & $\begin{array}{l}\text { Max gallons } \\
\text { sludge solids / } \\
\text { B-25 to meet } \\
\text { sum of } \\
\text { fractions } \\
\text { criteria }\end{array}$ & $\begin{array}{c}\text { Average } \\
\text { total TRU } \\
\text { Ci / } \\
\text { gallon } \\
\text { sludge } \\
\text { solids }\end{array}$ & $\begin{array}{c}\text { Maximum } \\
\text { total TRU } \\
\text { Ci / B-25 } \\
\text { to meet } \\
\text { sum-of- } \\
\text { fractions } \\
\text { criteria }\end{array}$ & $\begin{array}{c}\text { Minimum lb } \\
\text { waste weight / } \\
\text { B-25 to } \\
\text { meet TRU } \\
\text { limit of } \\
100 \mathrm{nCi} / \mathrm{g}\end{array}$ & $\begin{array}{l}\text { TRU nCi/g in B- } \\
25 \text { to meet sum-of- } \\
\text { fractions criteria } \\
\text { at } 5000 \mathrm{lb} \\
\text { maximum waste } \\
\text { weight }\end{array}$ \\
\hline A & $\begin{array}{l}\mathrm{B}=\mathrm{A} * 90 \mathrm{ft}^{3} / \mathrm{B}- \\
25 * 7.48 \mathrm{gal} / \mathrm{ft}^{3}\end{array}$ & $\mathrm{C}$ & $\mathrm{D}=\mathrm{B} * \mathrm{C}$ & $\begin{array}{l}=(\mathrm{D} * 1 \mathrm{E}+09 \mathrm{nCi} / \mathrm{Ci}) / \\
(100 \mathrm{nCi} / \mathrm{g} * 454 \mathrm{~g} / \mathrm{lb})\end{array}$ & $\begin{array}{l}=(\mathrm{D} * 1 \mathrm{E}+09 \mathrm{nCi} / \mathrm{Ci}) \\
/(5000 \mathrm{lb} * 454 \mathrm{~g} / \mathrm{lb})\end{array}$ \\
\hline $2.23 \mathrm{E}-04$ & $1.50 \mathrm{E}-01$ & $6.43 \mathrm{E}+00$ & $9.65 \mathrm{E}-01$ & $2.13 \mathrm{E}+04$ & $4.25 \mathrm{E}+02$ \\
\hline
\end{tabular}

\subsubsection{Nuclear Criticality Safety Criteria}

Sludge-contaminated LLW contains an insignificant quantity of fissionable material to impact nuclear criticality criteria. Attachment 11 and Table 3.9 determine the maximum quantity of sludge solids that could be placed in a B-25 prior to exceeding the 50-g Fissile Gram Equivalent (FGE) U-235 limit for the LAWV. This is equivalent to 21 gallons of sludge solids, a significantly greater volume than would meet LAWV and TRU waste limits for a B-25 waste container. Any such box will not be sent to the LAWV for disposal, therefore protecting this requirement.

\begin{tabular}{|c|c|c|c|c|c|c|c|}
\hline \multicolumn{7}{|c|}{ Table 3.9. Calculation of FGE Equivalent for H-Area } \\
Tank Farm Sludge-Contaminated Waste \\
\hline $\begin{array}{c}\text { Radio- } \\
\text { nuclide }\end{array}$ & $\begin{array}{c}\text { Activity } \\
\text { in } \\
\text { blended } \\
\text { sludge } \\
\text { solids } \\
\text { (Ci/gal) }\end{array}$ & $\begin{array}{c}\text { Maximum } \\
\text { gallons of } \\
\text { sludge } \\
\text { solids in a } \\
\text { B-25 to } \\
\text { meet FGE } \\
\text { equivalent }\end{array}$ & $\begin{array}{c}\text { Maximum } \\
\text { Curies } \\
\text { sludge } \\
\text { solids } \\
\text { in a } \\
\text { B-25 }\end{array}$ & $\begin{array}{c}\text { Specific } \\
\text { activity } \\
\text { (Ci/g) }\end{array}$ & $\begin{array}{c}\text { Maximum } \\
\text { mass } \\
\text { (grams) } \\
\text { in a } \\
\text { B-25 }\end{array}$ & $\begin{array}{c}\text { Equivalence } \\
\text { factor }\end{array}$ & $\begin{array}{c}\text { FGE } \\
\text { U-235 (g) }\end{array}$ \\
\hline & A & B & C=A*B & D & E=C/D & F & G=E*F \\
\hline U-233 & $1.78 \mathrm{E}-04$ & $\mathbf{2 1 . 2}$ & $3.76 \mathrm{E}-03$ & $9.648 \mathrm{E}-03$ & $3.90 \mathrm{E}-01$ & 1.4 & $5.46 \mathrm{E}-01$ \\
\hline $\mathrm{U}-235$ & $1.46 \mathrm{E}-06$ & $\mathbf{2 1 . 2}$ & $3.10 \mathrm{E}-05$ & $2.160 \mathrm{E}-06$ & $1.43 \mathrm{E}+01$ & 1.0 & $1.43 \mathrm{E}+01$ \\
\hline $\mathrm{Pu}-239$ & $5.88 \mathrm{E}-02$ & $\mathbf{2 1 . 2}$ & $1.25 \mathrm{E}+00$ & $6.132 \mathrm{E}-02$ & $2.03 \mathrm{E}+01$ & 1.6 & $3.25 \mathrm{E}+01$ \\
\hline $\mathrm{Pu}-241$ & $3.37 \mathrm{E}+00$ & $\mathbf{2 1 . 2}$ & $7.14 \mathrm{E}+01$ & $1.034 \mathrm{E}+02$ & $6.91 \mathrm{E}-01$ & 3.5 & $2.42 \mathrm{E}+00$ \\
\hline $\mathrm{Am}-242 \mathrm{~m}$ & $2.18 \mathrm{E}-04$ & $\mathbf{2 1 . 2}$ & $4.62 \mathrm{E}-03$ & $9.717 \mathrm{E}+00$ & $4.75 \mathrm{E}-04$ & 54.0 & $2.57 \mathrm{E}-02$ \\
\hline $\mathrm{Cm}-245$ & $4.13 \mathrm{E}-05$ & $\mathbf{2 1 . 2}$ & $8.75 \mathrm{E}-04$ & $1.716 \mathrm{E}-01$ & $5.10 \mathrm{E}-03$ & 24.0 & $1.22 \mathrm{E}-01$ \\
\hline $\mathrm{Cm}-247$ & $8.35 \mathrm{E}-10$ & $\mathbf{2 1 . 2}$ & $1.77 \mathrm{E}-08$ & $9.396 \mathrm{E}-05$ & $1.88 \mathrm{E}-04$ & 1.6 & $3.01 \mathrm{E}-04$ \\
\hline
\end{tabular}


WSRC-TR-2000-00249

Revision 2

Page 12

3.6 Documentation of the Sludge Fraction Distribution

The low-level waste characterization form (WCF) for H-Area Tank Farm Waste Stream, HTK-00002, included as Attachment 9, documents the distribution from the waste stream. For those packages determined to contain sufficient sludge to be determined mixed and/or transuranic, appropriate waste stream forms will be provided for each package.

The sludge solids distribution is used to evaluate HLW-contaminated waste in conjunction with the latest version of the distribution of the supernate waste stream, FHW-00001.

\subsection{Quantification}

\subsection{Quantification of Sludge and Supernate Fractions}

Quantification of radionuclides in sludge-contaminated waste requires quantification of both the supernate and sludge fractions in each waste cut. Independent quantification of Sr-90, indicative of the sludge fraction, and primarily Cs-137, indicative of the supernate fraction, is key to accurate characterization of sludge-contaminated waste. The sludge fraction distribution and scaling ratios to Sr-90 are provided in Attachments 8 and 9. The supernate fraction distribution and scaling factors to Cs- 137 can be found in the documentation for the latest version of the supernate waste stream, FHW-00001 (Reference 7, latest revision).

Scaling factors for the sludge fraction are tied to Sr-90. Although Sr-90 is present in the supernate fraction, it comprises less than $1 \%$ of total activity in the supernate fraction. For this reason, all Sr-90 identified in the sludge-contaminated waste will be attributed to the sludge fraction. Scaling ratios developed for the sludge fraction will be applied to the Sr-90 identified in sludge-contaminated waste.

Scaling factors for the supernate fraction are tied to Cs-137. Although Cs-137 is present in the sludge fraction, it typically comprises less than $5 \%$ of total activity in the sludge fraction (as is the case for waste stream HTK-00002). For this reason, all Cs-137 identified in sludge-contaminated waste for these waste streams will be attributed to the supernate fraction. Scaling ratios developed for supernate will be applied to the Cs-137 to determine the supernate radionuclides.

The two fractions of sludge-contaminated waste will be manifested separately. The dose of Cs-137 and Sr90 will be entered into two separate waste streams in WITS, representing the sludge and supernate fractions, respectively, which will calculate curies attributed to each radionuclide identified in the respective distributions. The two waste streams will be combined in WITS to create a single manifest.

\subsection{Quantification of Job Control Waste and Other Compactable Sludge-Contaminated Waste}

The relative ease with which gamma radiation from Cs-137 is detected makes estimation of the curie content of the supernate fraction of waste straightforward. Dose-to-curie methodologies for quantification of Cs-137 on waste containers have been developed and are currently in use (References 13 and 14).

Sr-90, a low-energy beta emitter, is not easily measured. Although a Beta Screening Tool (BST) has been developed as an improved alternative method for providing a dose associated with $\mathrm{Sr}-90$ (Reference 15), the BST methodology has not yet been implemented for waste quantification purposes. Until such time as the BST is field implemented, the actual quantity of Sr-90 present in the sludge fraction must be estimated by some other means.

The most conservative approach in quantification of a waste cut is to assume that all measured Cs-137 is attributed to both supernate and sludge fractions. For the sludge fraction, the known Sr-90 to Cs-137 ratio is utilized to estimate the maximum Sr-90 that could be present on the waste cut. This approach results in 
WSRC-TR-2000-00249

Revision 2

Page 13

double-manifesting of the Cs-137, over-manifesting of virtually all of the remaining radionuclides, and significantly over-estimating the sludge fraction.

It is preferable, therefore, to determine an appropriate split of the measured Cs-137 that can be attributed to the supernate and sludge fractions. In determining the appropriate split between these fractions, one must consider the effects of overestimating one fraction or the other. Over-estimating the sludge fraction will result in:

- under-manifesting of radionuclides attributed to supernate only (in this waste stream, the only radionuclide fitting this description is tritium, a PA radionuclide, present at $0.2 \%$ of total supernate activity), and

- over-manifesting of transuranics (a higher level of transuranics are present in sludge).

Over-estimating the supernate fraction will result in under-manifesting of radionuclides present in the sludge fraction only.

Determination of the split of Cs-137 contributed from the sludge and supernate fractions will be performed on a case-by-case basis for H-Area high level waste packages.

\subsection{Quantification of Non-Compactable Sludge-Contaminated Waste}

Estimation of the quantity of Cs-137 present on non-compactable waste, such as equipment or HEPA filters, is performed on a case-by-case basis. This is done by individual dose-to-curie runs, which take into account the specific geometry of the waste (Reference 16).

Application of BST methodology waste to non-compactable waste to determine the amount of Sr-90 present is not appropriate since the waste itself shields beta radiation and would result in unrealistically low measured values. Estimation of Sr-90 present in cuts of non-compactable waste will be performed by estimation of the amount of Cs-137 attributed to the sludge fraction in combination with the known relationship between Sr-90 and Cs-137. This will be performed on a case-by-case basis.

\subsection{Periodic Validation}

Provisions of WSRC 1S SRS Waste Acceptance Criteria Manual, Procedure 2.02, Revision 7 (Reference 4), require generators of routine wastes, including sludge-contaminated waste, to review and confirm the certification of each waste stream on a periodic basis. HLW sludge has been determined to require reevaluation every two years. 


\subsection{References}

1. D'Entremont, P. D., "HLW Sludge Characterization in Support of Low Level Waste Certification (U)," WSRC-TR-94-0579, Rev. 1., December 15, 1994.

2. Georgeton, G. K. and J. R. Hester., "Characterization of Radionuclides in HLW Sludge Based on Isotopic Distribution in Irradiated Assemblies (U)," WSRC-TR-94-0562, Rev. 1., January 27, 1995.

3. Hester, J. R., "High Level Waste Characterization System," WSRC-TR-96-0264, December 1996.

4. Procedure 2.02, "Low Level, Hazardous, TRU, Mixed, and PCB Waste Characterization Requirements," WSRC 1S Savannah River Site Waste Acceptance Criteria Manual, Revision 7, Savannah River Site, November 1, 2002.

5. O'Bryant, R. F. and J. K. W. Dunaway, "Characterization of Radionuclides in Waste Sludges from High Level Waste Tanks 40, 42 and 51 (U)", WSRC-TR-2000-00115, Revision 1, August 2000.

6. O"Bryant, R. F., Characterization of Radionuclides for $2 \mathrm{H}$ Evaporator Cleaning Transfers to Tank 42 (U), WSRC-TR-2001-00132, Revision 0, March 2001.

7. Ketusky, E. T. and R. F. O’Bryant, "HLW Supernate Radionuclide Characterization," WSRC-TR-94-0290, Revision 3, April 19, 1999.

8. Procedure 3.17, "Low Level Radioactive Waste Acceptance Criteria," WSRC 1S Savannah River Site Waste Acceptance Manual, Revision 7, Savannah River Site, September 16, 2002.

9. M:IWastelHlcats|WCTables|SludgeInv.xls, Reference Date: September 11, 2002, Retrieved from WCS February 20, 2003.

10. M:IWastelHlcats|WCTables\TankData.xls, Reference Date: September 11, 2002, Retrieved from WCS, February 20, 2003.

11. Canas, L. R., "F-Canyon Special Waste Compliance Plan for Tank 17.1 Americium/Curium Solution Discharge to HLW ESP Tank 51," X-WCP-F-00003, Revision 1, December 2002.

12. Bui, H., "Waste Compliance Plan for Liquid Waste Transfers from Tank 7 to WPT/ESP Tank $51-1^{\text {st }}$ Batch Transfer," WSRC-RP-2002-00364, Revision 1.

13. Jamison, M. E., "Characterization of Non-Routine Low-Level Waste from High Level Waste Activities (U)," WSRC-TR-95-0069, March 13, 1995

14. Hunt, P. D., "Dose-to-Curie Calculations," ESH-HPT-99-0019, Rev. 1, March 2, 1999.

15. Ross, R. H., E. T. Ketusky, and R. Petras, "HLW Characterization in Support of Low Level Waste Certification: HLW Sludge Beta Screening Tool," WSRC-TR-97-0555, Rev. 1, October 8, 1998.

16. SRS-DTC ${ }^{\mathrm{TM}}$ 3.1, WMG Inc., 16 Bank Street, Peekskill, NY 10556 
'M:IWASTE8\HIcats|WCSystem|[WCSystem.xls]TankData Reference Date: 9/11/02

Date Retrieved from WCS: $2 / 20 / 03$ 


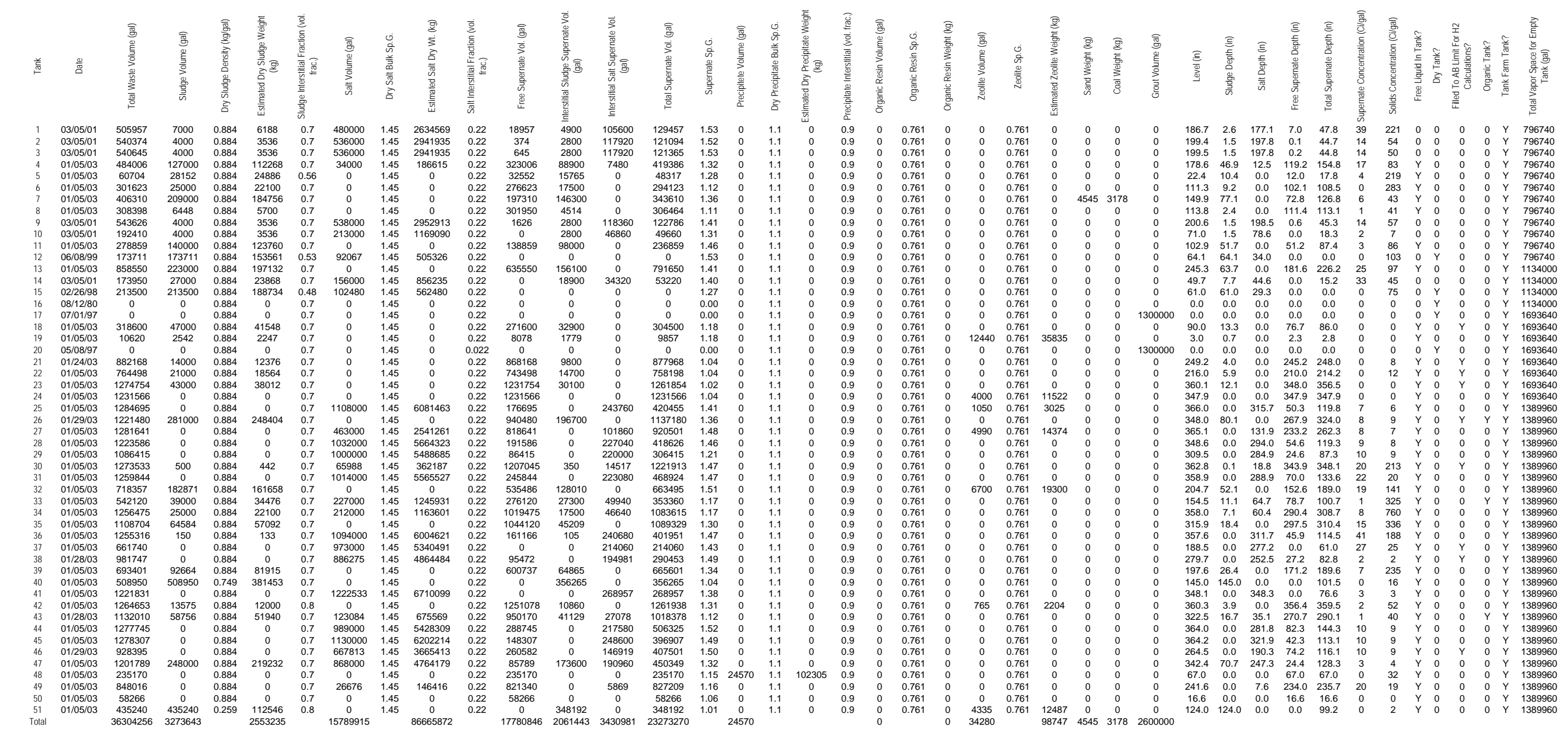


'M:IWASTE8\Hlcats\WCSystem\[WCSystem.xls]SludgeInv Reference Date: 9/11/02

Date Retrieved from WCS: $2 / 20 / 03$ 


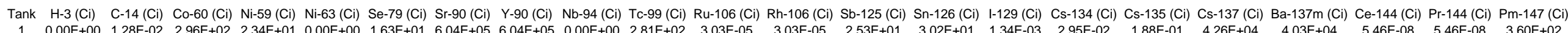

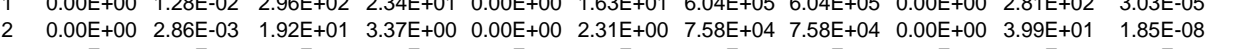
$\begin{array}{lllllllllll}0.00 \mathrm{E}+00 & 2.48 \mathrm{E}-03 & 2.19 \mathrm{E}+01 & 2.92 \mathrm{E}+00 & 0.00 \mathrm{E}+00 & 2.00 \mathrm{E}+00 & 6.87 \mathrm{E}+04 & 6.87 \mathrm{E}+04 & 0.00 \mathrm{E}+00 & 3.46 \mathrm{E}+01 & 1.24 \mathrm{E}-07\end{array}$

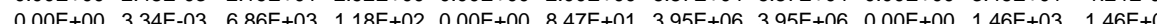

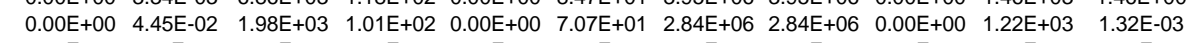

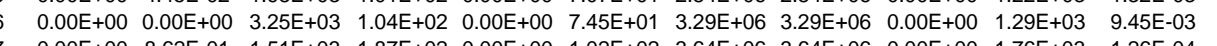

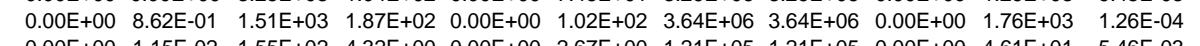

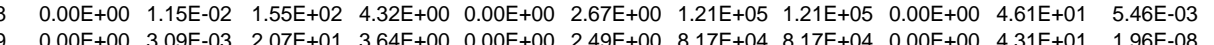

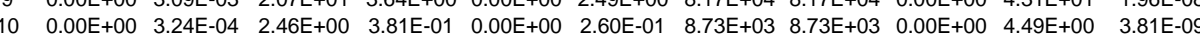

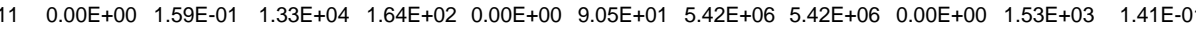

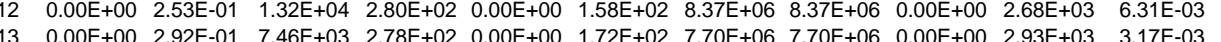

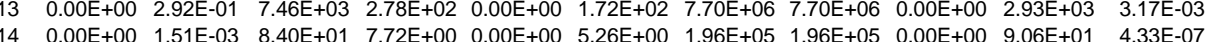

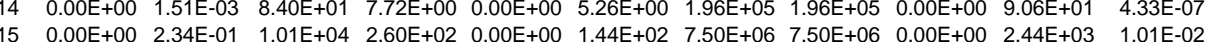

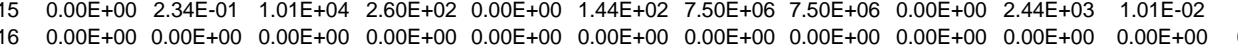

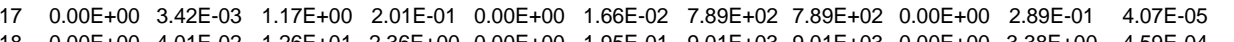

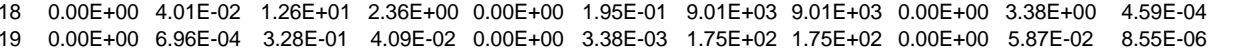

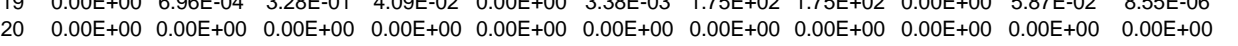

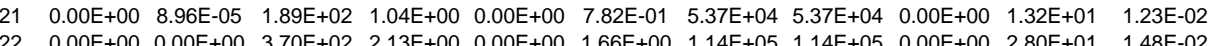

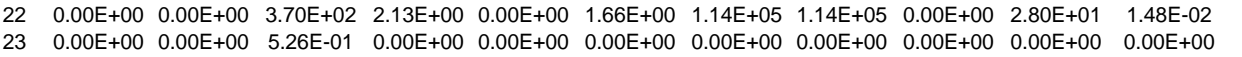
$\begin{array}{lllllll}85 \mathrm{E}-08 & 6.52 \mathrm{E}-01 & 4.29 \mathrm{E}+00 & 1.90 \mathrm{E}-04 & 3.87 \mathrm{E}-04 & 2.67 \mathrm{E}-02 & 5.39 \mathrm{E}+03 \\ 1.24 \mathrm{E}-07 & 1.01 \mathrm{E}+00 & 3.72 \mathrm{E}+00 & 1.65 \mathrm{E}-04 & 7.56 \mathrm{E}-04 & 23.02 & \end{array}$ $\begin{array}{lllllll} & \end{array}$

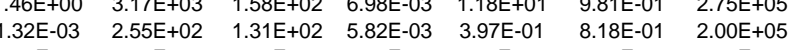
$\begin{array}{lllllll}.45 \mathrm{E}-03 & 5.82 \mathrm{E}+02 & 1.39 \mathrm{E}+02 & 6.14 \mathrm{E}-03 & 1.11 \mathrm{E}+00 & 8.63 \mathrm{E}-01 & 2.30 \mathrm{E}+05\end{array}$

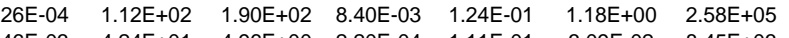
$\begin{array}{llllllll}4.46 \mathrm{E}-03 & 4.24 \mathrm{E}+01 & 4.96 \mathrm{E}+00 & 2.20 \mathrm{E}-04 & 1.11 \mathrm{E}-01 & 3.09 \mathrm{E}-02 & 8.45 \mathrm{E}+03\end{array}$ $\begin{array}{llllllll}1.0 \mathrm{E}-08 & 6.99 \mathrm{E}-01 & 4.63 \mathrm{E}+00 & 2.05 \mathrm{E}-04 & 4.14 \mathrm{E}-04 & 2.88 \mathrm{E}-02 & 5.81 \mathrm{E}+03 \\ 3.81 \mathrm{E}-09 & 8.82 \mathrm{E}-02 & 4.78 \mathrm{E}-01 & 2.13 \mathrm{E}-05 & 7.32 \mathrm{E}-05 & 3.01 \mathrm{E}-03 & 6.16 \mathrm{E}+02\end{array}$ $\begin{array}{lllllll}.41 \mathrm{E}-01 & 7.88 \mathrm{E}+02 & 8.29 \mathrm{E}+01 & 5.31 \mathrm{E}-03 & 4.52 \mathrm{E}+01 & 1.03 \mathrm{E}+00 & 2.98 \mathrm{E}+05\end{array}$ \begin{tabular}{lllllll}
$.31 \mathrm{E}-03$ & $4.56 \mathrm{E}+02$ & $1.62 \mathrm{E}+02$ & $9.69 \mathrm{E}-03$ & $1.72 \mathrm{E}+01$ & $1.79 \mathrm{E}+00$ & $4.71 \mathrm{E}+05$ \\
\hline
\end{tabular}

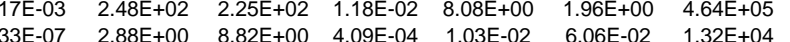
$\begin{array}{llllllll} & 3.01 \mathrm{E}-02 & 2.88 \mathrm{E}+00 & 8.82 \mathrm{E}+00 & 4.09 \mathrm{E}-04 & 1.03 \mathrm{E}-02 & 6.06 \mathrm{E}-02 & 1.32 \mathrm{E}+04 \\ .01 \mathrm{E}-02 & 3.01 \mathrm{E}+02 & 1.32 \mathrm{E}+02 & 8.43 \mathrm{E}-03 & 1.10 \mathrm{E}+01 & 1.63 \mathrm{E}+00 & 4.15 \mathrm{E}+05\end{array}$ $\begin{array}{lllllll}.00 \mathrm{E}+00 & 0.00 \mathrm{E}+00 & 0.00 \mathrm{E}+00 & 0.00 \mathrm{E}+00 & 0.00 \mathrm{E}+00 & 0.00 \mathrm{E}+00 & 0.00 \mathrm{E}+00\end{array}$

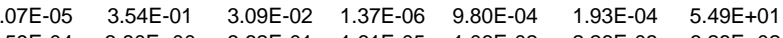

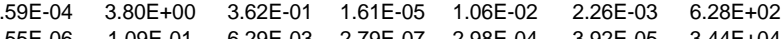

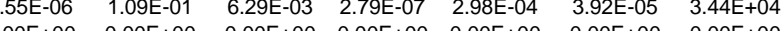
$\begin{array}{lllllll}.00 \mathrm{E}+00 & 0.00 \mathrm{E}+00 & 0.00 \mathrm{E}+00 & 0.00 \mathrm{E}+00 & 0.00 \mathrm{E}+00 & 0.00 \mathrm{E}+00 & 0.00 \mathrm{E}+00\end{array}$ $\begin{array}{llllllll}.48 \mathrm{E}-02 & 4.30 \mathrm{E}+01 & 1.51 \mathrm{E}+00 & 9.70 \mathrm{E}-05 & 3.14 \mathrm{E}+00 & 1.87 \mathrm{E}-02 & 6.17 \mathrm{E}+03 \\ 0\end{array}$ $\begin{array}{llllllll}0.00 \mathrm{E}+00 & 0.00 \mathrm{E}+00 & 0.00 \mathrm{E}+00 & 0.00 \mathrm{E}+00 & 2.71 \mathrm{E}-02 & 0.00 \mathrm{E}+00 & 4.49 \mathrm{E}+02\end{array}$

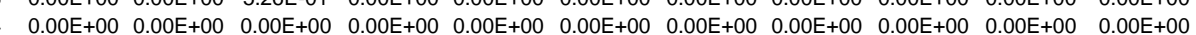

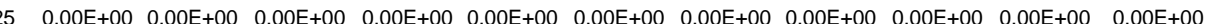

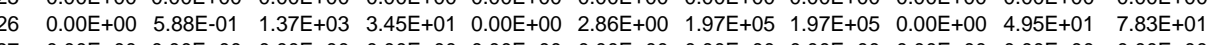

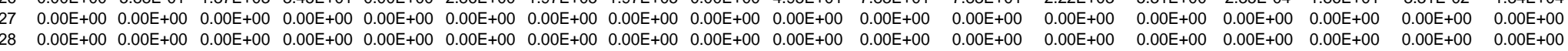

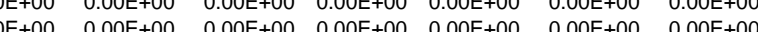
. $\begin{array}{llllllllllllll} & \end{array}$ $\begin{array}{lllllllllllllllll} & 0.00 E+00 & 0.00 E+00\end{array}$

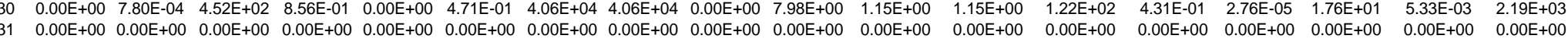

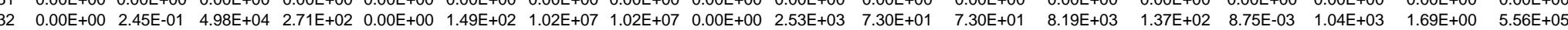

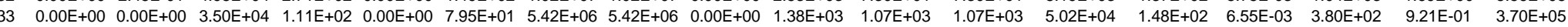

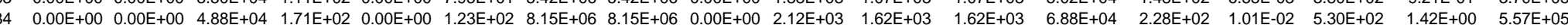

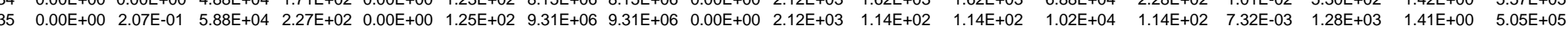

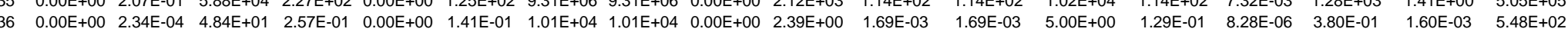

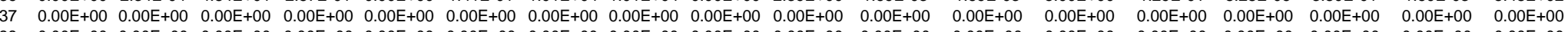

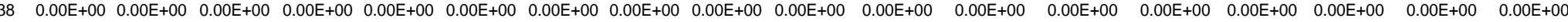

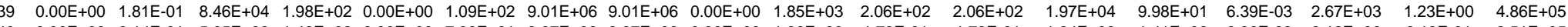

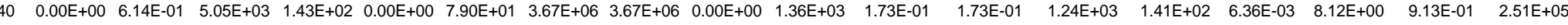

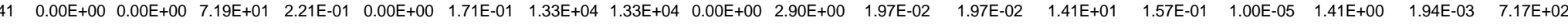

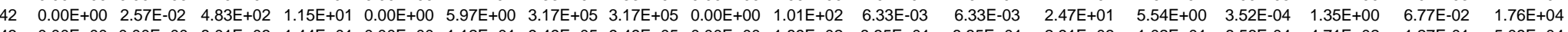

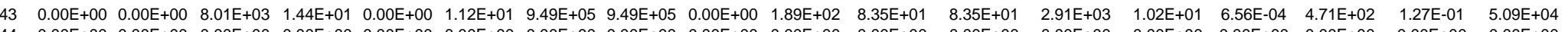

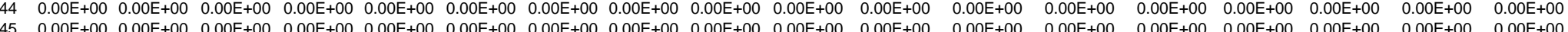

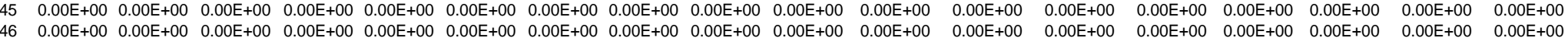

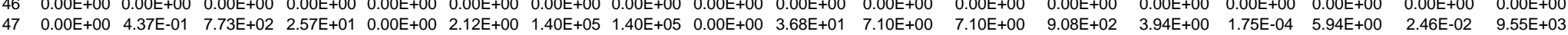

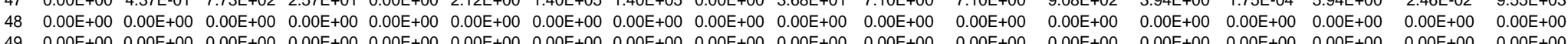

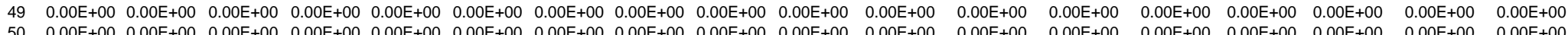

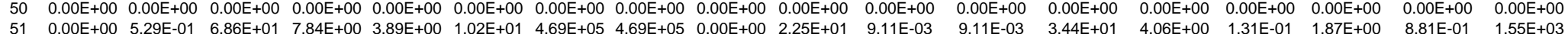

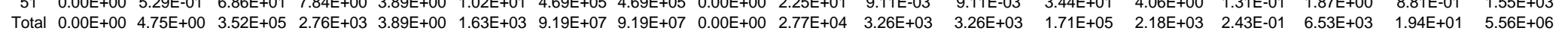

\begin{tabular}{|c|c|c|c|}
\hline & & & \\
\hline $0 \mathrm{E}+03$ & $51 \mathrm{E}-12$ & $4.51 \mathrm{E}-12$ & $8.57 \mathrm{E}+00$ \\
\hline $4.61 \mathrm{E}+03$ & $7.49 \mathrm{E}-11$ & $7.49 \mathrm{E}-11$ & $1.36 \mathrm{E}+01$ \\
\hline $2.60 \mathrm{E}+05$ & 4.57E-02 & 4.57E-02 & $5.23 \mathrm{E}+04$ \\
\hline $1.89 \mathrm{E}+05$ & $4.48 \mathrm{E}-06$ & $4.48 \mathrm{E}-06$ & 3.78E +03 \\
\hline $2.18 \mathrm{E}+05$ & $5.95 \mathrm{E}-05$ & $5.95 \mathrm{E}-05$ & $8.84 \mathrm{E}+03$ \\
\hline $2.44 \mathrm{E}+05$ & $2.45 \mathrm{E}-07$ & $2.45 \mathrm{E}-07$ & $1.58 \mathrm{E}+03$ \\
\hline $7.99 \mathrm{E}+03$ & $1.60 \mathrm{E}-04$ & 1.60E-04 & $6.70 \mathrm{E}+02$ \\
\hline $5.49 E+03$ & $4.74 \mathrm{E}-12$ & $4.74 \mathrm{E}-12$ & $9.18 \mathrm{E}+00$ \\
\hline $5.83 \mathrm{E}+02$ & $1.36 \mathrm{E}-12$ & $1.36 \mathrm{E}-12$ & $1.18 \mathrm{E}+00$ \\
\hline $2.82 \mathrm{E}+05$ & $2.19 \mathrm{E}-02$ & 2.19E-02 & $2.05 \mathrm{E}+04$ \\
\hline $4.46 \mathrm{E}+05$ & $1.95 \mathrm{E}-04$ & $1.95 \mathrm{E}-04$ & 1.12E+04 \\
\hline $4.38 \mathrm{E}+05$ & $1.10 \mathrm{E}-04$ & 1.10E-04 & $5.79 \mathrm{E}+03$ \\
\hline $1.25 \mathrm{E}+04$ & $1.39 \mathrm{E}-09$ & 1.39E-09 & $4.30 \mathrm{E}+01$ \\
\hline 3.93E+05 & $1.34 \mathrm{E}-03$ & 1.34E-03 & $7.41 \mathrm{E}+03$ \\
\hline $0.00 \mathrm{E}+00$ & $0.00 \mathrm{E}+00$ & $0.00 \mathrm{E}+00$ & $0.00 \mathrm{E}+00$ \\
\hline $5.20 \mathrm{E}+01$ & $7.20 \mathrm{E}-07$ & $7.20 \mathrm{E}-07$ & $5.64 \mathrm{E}+00$ \\
\hline $5.94 \mathrm{E}+02$ & $8.20 \mathrm{E}-06$ & $8.20 \mathrm{E}-06$ & $6.06 \mathrm{E}+01$ \\
\hline $3.25 \mathrm{E}+04$ & $1.02 \mathrm{E}-07$ & $1.02 \mathrm{E}-07$ & $1.73 \mathrm{E}+00$ \\
\hline $0.00 E+00$ & $0.00 E+00$ & $0.00 \mathrm{E}+00$ & $0.00 \mathrm{E}+00$ \\
\hline $2.76 \mathrm{E}+03$ & $1.97 \mathrm{E}-03$ & $1.97 \mathrm{E}-03$ & $6.73 E+02$ \\
\hline $5.83 \mathrm{E}+03$ & 2.07E-03 & 2.07E-03 & $1.16 \mathrm{E}+03$ \\
\hline $4.25 \mathrm{E}+02$ & $0.00 \mathrm{E}+00$ & $0.00 \mathrm{E}+00$ & $0.00 \mathrm{E}+00$ \\
\hline $0.00 \mathrm{E}+00$ & $0.00 \mathrm{E}+00$ & $0.00 E+00$ & $0.00 \mathrm{E}+00$ \\
\hline $0.00 E+00$ & $0.00 E+00$ & $0.00 \mathrm{E}+00$ & $0.00 E+00$ \\
\hline $1.27 \mathrm{E}+04$ & $2.39 \mathrm{E}+01$ & $2.39 \mathrm{E}+01$ & $4.06 \mathrm{E}+04$ \\
\hline $0.00 \mathrm{E}+00$ & $0.00 \mathrm{E}+00$ & $0.00 E+00$ & $0.00 \mathrm{E}+00$ \\
\hline $0.00 E+00$ & $0.00 E+00$ & $0.00 \mathrm{E}+00$ & $0.00 \mathrm{E}+00$ \\
\hline $0.00 \mathrm{E}+00$ & $0.00 \mathrm{E}+00$ & $0.00 \mathrm{E}+00$ & $0.00 \mathrm{E}+00$ \\
\hline $2.07 \mathrm{E}+03$ & $6.98 \mathrm{E}-01$ & $6.98 \mathrm{E}-01$ & $3.58 \mathrm{E}+03$ \\
\hline $0.00 E+00$ & $0.00 E+00$ & $0.00 \mathrm{E}+00$ & $0.00 \mathrm{E}+00$ \\
\hline $5.26 \mathrm{E}+05$ & $5.16 \mathrm{E}+01$ & $5.16 \mathrm{E}+01$ & $2.35 \mathrm{E}+05$ \\
\hline $3.50 \mathrm{E}+05$ & $2.87 \mathrm{E}+02$ & $2.87 \mathrm{E}+02$ & $9.06 \mathrm{E}+05$ \\
\hline $5.27 \mathrm{E}+05$ & $3.92 \mathrm{E}+02$ & $3.92 \mathrm{E}+02$ & $1.24 \mathrm{E}+\mathrm{C}$ \\
\hline $4.78 \mathrm{E}+05$ & $1.11 \mathrm{E}+02$ & $1.11 \mathrm{E}+02$ & $2.94 \mathrm{E}+05$ \\
\hline $5.18 \mathrm{E}+02$ & $1.99 \mathrm{E}-04$ & $1.99 \mathrm{E}-04$ & $1.35 \mathrm{E}+02$ \\
\hline $0.00 \mathrm{E}+00$ & $0.00 \mathrm{E}+00$ & $0.00 \mathrm{E}+00$ & $0.00 \mathrm{E}+00$ \\
\hline $0.00 E+00$ & $0.00 \mathrm{E}+00$ & $0.00 \mathrm{E}+00$ & $0.00 \mathrm{E}+00$ \\
\hline $4.60 E+05$ & $2.13 E+02$ & $2.13 E+02$ & $5.72 \mathrm{E}+05$ \\
\hline $2.37 E+05$ & $7.75 \mathrm{E}-03$ & $7.75 \mathrm{E}-03$ & $2.03 E+04$ \\
\hline $6.78 \mathrm{E}+02$ & $4.68 \mathrm{E}-03$ & 4.68E-03 & 3.96E+02 \\
\hline $1.66 \mathrm{E}+04$ & $9.78 \mathrm{E}-04$ & $9.78 \mathrm{E}-04$ & $6.24 \mathrm{E}+02$ \\
\hline $4.82 E+04$ & $1.25 \mathrm{E}+02$ & $1.25 \mathrm{E}+02$ & $8.64 \mathrm{E}+04$ \\
\hline $0.00 \mathrm{E}+00$ & $0.00 \mathrm{E}+00$ & $0.00 E+00$ & $0.00 \mathrm{E}+00$ \\
\hline $0.00 \mathrm{E}+00$ & $0.00 \mathrm{E}+00$ & $0.00 E+00$ & $0.00 \mathrm{E}+0$ \\
\hline $0.00 \mathrm{E}+00$ & $0.00 \mathrm{E}+00$ & $0.00 \mathrm{E}+00$ & $0.00 \mathrm{E}+00$ \\
\hline & -01 & $8.68 \mathrm{E}-01$ & 1.61 \\
\hline $0.00 \mathrm{E}+00$ & $0.00 \mathrm{E}+00$ & $0.00 \mathrm{E}+00$ & $0.00 \mathrm{E}+00$ \\
\hline D & $0.00 \mathrm{E}+00$ & $0.00 \mathrm{E}+00$ & $0.00 \mathrm{E}+$ \\
\hline & $0.00 \mathrm{E}+00$ & $0.00 \mathrm{E}+00$ & \\
\hline & $1.39 \mathrm{E}-03$ & $1.39 \mathrm{E}-03$ & \\
\hline & & & \\
\hline
\end{tabular}


WCS Sludge Inventory

Reference Date: 9/11/02

Latest Data Update: 1/29/03
Date Retrieved: 2/20/03

\begin{tabular}{|c|c|c|c|c|c|c|c|c|c|c|c|c|c|c|c|c|c|c|c|}
\hline Tank & Eu-154 (Ci) & $1-232(\mathrm{Ci})$ & -232 (Ci) & U-233 (Ci) & U-234 (Ci) & U-235 (Ci) & U-236 (Ci) & U-238 (Ci) & $\mathrm{Np}-237$ (Ci) & Pu-238 (Ci) & Pu-239 (Ci) & Pu-240 (Ci) & Pu-241 (Ci) & Pu-242 (Ci) & Ingrown Am-241 (Ci) & Am-241 (Ci) & $\mathrm{Am}-242 \mathrm{~m}(\mathrm{Ci})$ & Cm-244 (Ci) & $\mathrm{m}-245(\mathrm{c}$ \\
\hline 1 & $1.18 \mathrm{E}+03$ & $0.00 \mathrm{E}+00$ & $1.27 \mathrm{E}-02$ & $0.00 E+00$ & $0.00 \mathrm{E}+00$ & $1.76 \mathrm{E}-02$ & $0.00 E+00$ & 4.39E-01 & $6.41 \mathrm{E}-01$ & $5.19 \mathrm{E}+02$ & $1.33 \mathrm{E}+02$ & $2.97 \mathrm{E}+01$ & $1.85 \mathrm{E}+02$ & $6.12 \mathrm{E}-03$ & $4.06 \mathrm{E}+01$ & $2.11 \mathrm{E}+03$ & $2.66 \mathrm{E}+00$ & 4.25E-01 & $4.62 \mathrm{E}-07$ \\
\hline 2 & $1.08 \mathrm{E}+02$ & $0.00 \mathrm{E}+00$ & $1.73 \mathrm{E}-03$ & $0.00 \mathrm{E}+00$ & $0.00 \mathrm{E}+00$ & $8.12 \mathrm{E}-04$ & $0.00 E+00$ & $2.02 \mathrm{E}-02$ & $2.12 \mathrm{E}-01$ & $1.38 \mathrm{E}+02$ & $1.98 \mathrm{E}+01$ & $4.42 \mathrm{E}+00$ & 2.10E+01 & $9.08 \mathrm{E}-04$ & $6.02 \mathrm{E}+00$ & $2.97 E+02$ & $3.69 \mathrm{E}-01$ & $4.94 \mathrm{E}-02$ & $6.55 \mathrm{E}-08$ \\
\hline 3 & $1.10 \mathrm{E}+02$ & $0.00 \mathrm{E}+00$ & $1.52 \mathrm{E}-03$ & $0.00 \mathrm{E}+00$ & $0.00 \mathrm{E}+00$ & $2.03 \mathrm{E}-03$ & $0.00 \mathrm{E}+00$ & $5.06 \mathrm{E}-02$ & $3.78 \mathrm{E}-01$ & $1.66 \mathrm{E}+02$ & $2.38 \mathrm{E}+01$ & $5.31 \mathrm{E}+00$ & $3.05 \mathrm{E}+01$ & $1.09 \mathrm{E}-03$ & $7.30 \mathrm{E}+00$ & $2.57 \mathrm{E}+02$ & 3.22E-01 & $4.61 \mathrm{E}-02$ & $5.67 \mathrm{E}-08$ \\
\hline 4 & $1.41 \mathrm{E}+04$ & $0.00 \mathrm{E}+00$ & $7.16 \mathrm{E}-02$ & $0.00 \mathrm{E}+00$ & $0.00 \mathrm{E}+00$ & $7.77 \mathrm{E}-02$ & $0.00 \mathrm{E}+00$ & $3.34 \mathrm{E}+00$ & $2.98 \mathrm{E}+00$ & $6.05 \mathrm{E}+02$ & $5.98 \mathrm{E}+02$ & $1.34 \mathrm{E}+02$ & $1.28 \mathrm{E}+03$ & $2.75 \mathrm{E}-02$ & $1.75 \mathrm{E}+02$ & 1.12E+04 & $1.45 \mathrm{E}+01$ & $3.21 E+00$ & 2.40E-06 \\
\hline 5 & $6.64 \mathrm{E}+03$ & $0.00 \mathrm{E}+00$ & $5.69 \mathrm{E}-02$ & $0.00 E+00$ & $0.00 \mathrm{E}+00$ & $1.05 \mathrm{E}-01$ & $0.00 E+00$ & $2.48 \mathrm{E}+00$ & $4.19 E+00$ & $2.89 \mathrm{E}+03$ & $4.82 \mathrm{E}+02$ & $1.15 \mathrm{E}+02$ & $8.75 \mathrm{E}+02$ & $3.40 \mathrm{E}-02$ & $1.72 \mathrm{E}+02$ & $9.23 \mathrm{E}+03$ & 1.18E+01 & $2.09 \mathrm{E}+00$ & \\
\hline 6 & $9.29 E+03$ & $0.00 \mathrm{E}+00$ & $6.18 \mathrm{E}-02$ & $0.00 \mathrm{E}+00$ & $0.00 \mathrm{E}+00$ & $6.65 \mathrm{E}-02$ & $0.00 E+00$ & $2.49 \mathrm{E}+00$ & $8.63 \mathrm{E}-01$ & $0.00 \mathrm{E}+00$ & $2.55 \mathrm{E}+02$ & $8.84 \mathrm{E}+01$ & $1.13 \mathrm{E}+03$ & $1.74 \mathrm{E}-01$ & $1.73 \mathrm{E}+02$ & $9.82 \mathrm{E}+03$ & 1.27E+01 & $2.55 \mathrm{E}+00$ & $2.12 \mathrm{E}-06$ \\
\hline 7 & $6.53 E+03$ & $0.00 \mathrm{E}+00$ & $8.59 \mathrm{E}-02$ & $0.00 \mathrm{E}+00$ & $0.00 \mathrm{E}+00$ & $3.79 \mathrm{E}-01$ & $0.00 \mathrm{E}+00$ & $9.16 \mathrm{E}+00$ & $8.40 \mathrm{E}+00$ & $2.43 E+04$ & $3.67 \mathrm{E}+03$ & $8.76 \mathrm{E}+02$ & $7.12 \mathrm{E}+03$ & $2.82 \mathrm{E}-01$ & $1.29 \mathrm{E}+03$ & 1.27E+04 & $1.59 \mathrm{E}+01$ & $2.50 \mathrm{E}+00$ & $2.90 \mathrm{E}-06$ \\
\hline 8 & $3.81 E+02$ & $0.00 \mathrm{E}+00$ & 2.35E-03 & $0.00 \mathrm{E}+00$ & $0.00 \mathrm{E}+00$ & $5.43 \mathrm{E}-03$ & $0.00 \mathrm{E}+00$ & $2.50 \mathrm{E}-01$ & 1.13E-01 & $4.54 \mathrm{E}+02$ & $7.13 \mathrm{E}+01$ & $1.68 \mathrm{E}+01$ & $1.81 \mathrm{E}+02$ & $2.12 \mathrm{E}-02$ & $1.72 \mathrm{E}+01$ & 3.45E+02 & $5 \mathrm{E}-01$ & & \\
\hline 9 & 1.17E+02 & $0.00 \mathrm{E}+00$ & 1.87E-03 & $0.00 E+00$ & $0.00 \mathrm{E}+00$ & $1.18 \mathrm{E}-03$ & $0.00 E+00$ & $2.94 \mathrm{E}-02$ & $2.01 \mathrm{E}-01$ & 4.37E+01 & $6.24 \mathrm{E}+00$ & $1.39 \mathrm{E}+00$ & $6.57 \mathrm{E}+00$ & 2.87E-04 & $1.88 \mathrm{E}+00$ & 3. $20 \mathrm{E}+02$ & $3.98 \mathrm{E}-01$ & $5.33 \mathrm{E}-02$ & 7E-08 \\
\hline 10 & $1.38 \mathrm{E}+01$ & $0.00 \mathrm{E}+00$ & $1.92 \mathrm{E}-04$ & $0.00 \mathrm{E}+00$ & $0.00 \mathrm{E}+00$ & $2.28 \mathrm{E}-04$ & $0.00 E+00$ & $5.69 \mathrm{E}-03$ & 4.35E-02 & $2.21 \mathrm{E}+01$ & $3.16 \mathrm{E}+00$ & 7.06E-01 & $3.56 \mathrm{E}+00$ & $1.45 \mathrm{E}-04$ & $9.72 \mathrm{E}-01$ & $3.32 \mathrm{E}+01$ & $4.13 \mathrm{E}-02$ & $7.22 \mathrm{E}-03$ & $2.98 \mathrm{E}-07$ \\
\hline 11 & $5.99 \mathrm{E}+04$ & $1.43 \mathrm{E}-02$ & $1.66 \mathrm{E}-04$ & $2.04 \mathrm{E}+00$ & $1.68 \mathrm{E}+00$ & 3.16E-02 & $2.59 \mathrm{E}-01$ & $5.86 \mathrm{E}-02$ & $1.11 \mathrm{E}+00$ & $1.53 \mathrm{E}+05$ & $1.49 \mathrm{E}+03$ & $9.34 \mathrm{E}+02$ & $6.08 \mathrm{E}+04$ & $1.99 \mathrm{E}+00$ & $5.96 \mathrm{E}+03$ & $7.10 \mathrm{E}+03$ & $8.46 \mathrm{E}+00$ & $4.87 \mathrm{E}+01$ & \\
\hline 12 & $7.18 \mathrm{E}+04$ & $1.36 \mathrm{E}+00$ & 1.41E-02 & 3.83E+01 & $3.58 \mathrm{E}+00$ & $6.74 \mathrm{E}-02$ & $2.84 \mathrm{E}-01$ & $6.79 \mathrm{E}-01$ & $7.94 \mathrm{E}+00$ & $1.41 \mathrm{E}+05$ & $2.32 \mathrm{E}+03$ & $1.28 \mathrm{E}+03$ & $3.69 E+04$ & $1.85 \mathrm{E}+00$ & 4.46E+03 & $1.34 \mathrm{E}+04$ & $1.59 \mathrm{E}+01$ & $6.68 \mathrm{E}+01$ & $8 \mathrm{E}-03$ \\
\hline 13 & $4.71 \mathrm{E}+04$ & $1.98 \mathrm{E}-01$ & $5.54 \mathrm{E}-02$ & $4.06 \mathrm{E}+01$ & $5.73 \mathrm{E}+00$ & $1.57 \mathrm{E}-01$ & $5.91 \mathrm{E}-01$ & $1.83 \mathrm{E}+00$ & $1.47 \mathrm{E}+01$ & $5.56 \mathrm{E}+04$ & $1.46 \mathrm{E}+03$ & $6.03 \mathrm{E}+02$ & $1.21 \mathrm{E}+04$ & $4.00 \mathrm{E}-01$ & $2.23 \mathrm{E}+03$ & $1.65 \mathrm{E}+04$ & $2.01 E+01$ & $4.55 \mathrm{E}+01$ & $5.98 \mathrm{E}-03$ \\
\hline 14 & $5.31 \mathrm{E}+02$ & $1.06 \mathrm{E}-02$ & 3.22E-03 & $3.74 \mathrm{E}-01$ & $5.13 \mathrm{E}-02$ & 4.15E-03 & $4.41 \mathrm{E}-03$ & $7.91 \mathrm{E}-02$ & $5.48 \mathrm{E}-01$ & $2.50 \mathrm{E}+02$ & $6.04 \mathrm{E}+01$ & $1.95 \mathrm{E}+01$ & 1.12E+02 & 3.57E-03 & $\mathrm{E}+01$ & $6.28 \mathrm{E}+02$ & $7.80 \mathrm{E}-01$ & 4.63E-01 & \\
\hline 15 & $6.08 \mathrm{E}+04$ & $1.13 \mathrm{E}+00$ & $0.00 \mathrm{E}+00$ & $1.39 \mathrm{E}+01$ & $3.79 E+00$ & $6.12 \mathrm{E}-02$ & $3.59 \mathrm{E}-01$ & 1. $40 \mathrm{E}-03$ & $3.55 \mathrm{E}+00$ & $5.82 \mathrm{E}+04$ & $1.22 \mathrm{E}+03$ & $5.90 \mathrm{E}+02$ & $1.39 \mathrm{E}+04$ & $4.45 \mathrm{E}-01$ & $5 \mathrm{E}+03$ & +04 & $1.32 \mathrm{E}+01$ & +01 & $8.64 \mathrm{E}-03$ \\
\hline 16 & $0.00 \mathrm{E}+00$ & $0.00 \mathrm{E}+00$ & $0.00 E+00$ & $0.00 \mathrm{E}+00$ & $0.00 \mathrm{E}+00$ & $0.00 \mathrm{E}+00$ & $0.00 \mathrm{E}+00$ & $0.00 \mathrm{E}+00$ & $0.00 \mathrm{E}+00$ & $0.00 \mathrm{E}+00$ & $0.00 \mathrm{E}+00$ & $0.00 \mathrm{E}+00$ & $0.00 \mathrm{E}+00$ & $0.00 \mathrm{E}+00$ & $0.00 \mathrm{E}+00$ & $0.00 \mathrm{E}+00$ & $0.00 \mathrm{E}+00$ & $0.00 \mathrm{E}+00$ & $0.00 \mathrm{E}+00$ \\
\hline 17 & $2.69 \mathrm{E}+00$ & $0.00 \mathrm{E}+00$ & $4.88 \mathrm{E}-05$ & $0.00 \mathrm{E}+00$ & $0.00 \mathrm{E}+00$ & 3.29E-04 & $0.00 E+00$ & $2.04 \mathrm{E}-02$ & $0.00 \mathrm{E}+00$ & $8.38 \mathrm{E}+01$ & $1.20 \mathrm{E}+01$ & $3.17 \mathrm{E}+00$ & $4.45 \mathrm{E}+01$ & $4.55 \mathrm{E}-03$ & & & $0.00 E+00$ & & 4.77E-10 \\
\hline 18 & $2.95 \mathrm{E}+01$ & $0.00 \mathrm{E}+00$ & $5.66 \mathrm{E}-04$ & $0.00 \mathrm{E}+00$ & $0.00 \mathrm{E}+00$ & $4.30 \mathrm{E}-03$ & $0.00 \mathrm{E}+00$ & $2.31 \mathrm{E}-01$ & $0.00 \mathrm{E}+00$ & $9.85 \mathrm{E}+02$ & $1.41 \mathrm{E}+02$ & $3.60 \mathrm{E}+01$ & $6.58 \mathrm{E}+02$ & $4.61 \mathrm{E}-02$ & +01 & & $\mathrm{E}+00$ & -03 & $0 \mathrm{E}-09$ \\
\hline 19 & $6.91 \mathrm{E}-01$ & $0.00 \mathrm{E}+00$ & $1.03 \mathrm{E}-05$ & $0.00 \mathrm{E}+00$ & $0.00 E+00$ & $6.80 \mathrm{E}-05$ & $0.00 \mathrm{E}+00$ & $6.21 \mathrm{E}-03$ & $0.00 E+00$ & $2.55 \mathrm{E}+01$ & $3.64 \mathrm{E}+00$ & 8.13E-01 & $1.06 \mathrm{E}+02$ & 1.67E-03 & $02 \mathrm{E}+01$ & $\mathrm{E}+00$ & $0.00 \mathrm{E}+00$ & 1.47E-04 & $9.71 \mathrm{E}-11$ \\
\hline 20 & $0.00 \mathrm{E}+00$ & $0.00 \mathrm{E}+00$ & $0.00 E+00$ & $0.00 \mathrm{E}+00$ & $0.00 \mathrm{E}+00$ & $0.00 \mathrm{E}+00$ & $.00 \mathrm{E}+00$ & $0.00 \mathrm{E}+00$ & $0.00 E+00$ & & & & & +00 & & & & & \\
\hline 21 & $8.04 \mathrm{E}+02$ & $5.67 \mathrm{E}-06$ & $0.00 \mathrm{E}+00$ & $1.73 \mathrm{E}-01$ & $1.71 \mathrm{E}-01$ & $2.36 \mathrm{E}-03$ & $3.50 \mathrm{E}-02$ & $1.60 \mathrm{E}-03$ & $1.05 \mathrm{E}-01$ & $E+02$ & $1.09 \mathrm{E}+00$ & $6.34 \mathrm{E}-01$ & +01 & 33E-04 & +00 & 01 & 02 & -01 & -05 \\
\hline 22 & $1.65 \mathrm{E}+03$ & $0.00 \mathrm{E}+00$ & $0.00 \mathrm{E}+00$ & $1.07 \mathrm{E}+00$ & 3.86E-01 & $5.91 \mathrm{E}-03$ & $6.36 \mathrm{E}-02$ & 8.60E-03 & $2.35 \mathrm{E}-01$ & $1.63 \mathrm{E}+03$ & $0.00 \mathrm{E}+00$ & $0.00 \mathrm{E}+00$ & $E+00$ & $0.00 \mathrm{E}+00$ & $E+00$ & +01 & $\mathrm{E}-01$ & $E+00$ & E-05 \\
\hline 23 & $0.00 \mathrm{E}+00$ & $0.00 \mathrm{E}+00$ & $0.00 \mathrm{E}+00$ & $0.00 \mathrm{E}+00$ & $0.00 \mathrm{E}+00$ & $0.00 \mathrm{E}+00$ & $0.00 \mathrm{E}+00$ & $0.00 \mathrm{E}+00$ & $0.00 \mathrm{E}+00$ & & & $0.00 \mathrm{E}+00$ & & $E+00$ & & & & & \\
\hline 24 & $0.00 \mathrm{E}+00$ & $0.00 \mathrm{E}+00$ & $0.00 \mathrm{E}+00$ & $0.00 \mathrm{E}+00$ & $0.00 \mathrm{E}+00$ & $0.00 \mathrm{E}+00$ & $0.00 \mathrm{E}+00$ & $0.00 \mathrm{E}+00$ & $0.00 \mathrm{E}+00$ & $\mathrm{E}+00$ & $E+00$ & $0.00 \mathrm{E}+00$ & $E+00$ & $0 \mathrm{E}+00$ & $E+00$ & +00 & +00 & +00 & +00 \\
\hline 25 & $0.00 \mathrm{E}+00$ & $0 \mathrm{E}+00$ & $0.00 E+00$ & $0.00 E+00$ & $0.00 \mathrm{E}+00$ & $0.00 \mathrm{E}+00$ & $0.00 E+00$ & $0.00 \mathrm{E}+00$ & $0.00 \mathrm{E}+00$ & $E+00$ & $=+00$ & $E+00$ & +00 & $0 \mathrm{E}+00$ & +00 & 00 & +00 & +00 & $E+00$ \\
\hline 26 & & & & & & -02 & & & & & & & & & & & & & \\
\hline 27 & $0.00 \mathrm{E}+00$ & $0.00 \mathrm{E}+00$ & $0.00 \mathrm{E}+00$ & $0.00 \mathrm{E}+00$ & $0.00 \mathrm{E}+00$ & $0.00 \mathrm{E}+00$ & $0.00 \mathrm{E}+00$ & $0.00 \mathrm{E}+00$ & $0.00 \mathrm{E}+00$ & +00 & +00 & +00 & +00 & $E+00$ & $E+00$ & & $E+00$ & +00 & $E+00$ \\
\hline 28 & $0.00 \mathrm{E}+00$ & $0.00 \mathrm{E}+00$ & $0.00 E+00$ & $0.00 \mathrm{E}+00$ & $0.00 \mathrm{E}+00$ & $0.00 \mathrm{E}+00$ & $0.00 E+00$ & $0.00 \mathrm{E}+00$ & $0.00 \mathrm{E}+00$ & +00 & +00 & +00 & +00 & $E+00$ & +00 & bo & $=00$ & +00 & $E+00$ \\
\hline 29 & & & & $0.00 \mathrm{E}+00$ & & $0.00 \mathrm{E}$ & & & & & & & & & & & & & \\
\hline 30 & $9.82 \mathrm{E}+02$ & $E+00$ & $00 \mathrm{E}+00$ & $0.00 \mathrm{E}+00$ & $1.83 \mathrm{E}-02$ & 3.25E-04 & 3.37E-03 & $1.20 \mathrm{E}-05$ & $=-03$ & +03 & +01 & +01 & +03 & $=-02$ & +01 & & $=02$ & -01 & $E-05$ \\
\hline 31 & $E+00$ & & $0 \mathrm{E}+00$ & $0.00 \mathrm{E}+00$ & $0.00 \mathrm{E}+00$ & $0.00 \mathrm{E}+00$ & & 0.00 & & & & & & & & & & & \\
\hline 32 & & & & & & & & & & & & & & & & & & & \\
\hline 33 & $4.00 \mathrm{E}+04$ & 00 & $7.84 \mathrm{E}-02$ & $3.74 \mathrm{E}-07$ & $3.12 \mathrm{E}-03$ & $1.68 \mathrm{E}-01$ & $7.48 \mathrm{E}-02$ & 2.47E+01 & +00 & +01 & +03 & +03 & +04 & $=-02$ & +02 & & $E+01$ & +00 & $\mathrm{E}-06$ \\
\hline 34 & $5.74 \mathrm{E}+04$ & & $1.20 \mathrm{E}-01$ & $0.00 \mathrm{E}+00$ & $0.00 \mathrm{E}+00$ & 1. $14 \mathrm{E}-01$ & $0.00 \mathrm{E}+00$ & $8.05 \mathrm{E}+00$ & & & & & & & & & & & $E-06$ \\
\hline 35 & & & & & & $=-02$ & & & & & & & & & & & & & \\
\hline 36 & $1.59 \mathrm{E}+02$ & & $0.00 \mathrm{E}+00$ & $0.00 \mathrm{E}+00$ & 7.26E-03 & $1.41 \mathrm{E}-04$ & $2.56 \mathrm{E}-03$ & 4.60E-05 & 03 & & & & & & +01 & & & -02 & $E-06$ \\
\hline 37 & $0.00 \mathrm{E}+00$ & & +00 & & $0.00 \mathrm{E}+00$ & $0.00 \mathrm{E}+00$ & & & & & & & & & & & & & $E+00$ \\
\hline 38 & 0. & & +00 & 0.0 & $0.00 \mathrm{E}+00$ & $0.00 \mathrm{E}+00$ & 0.00 & 0.00 & & & & & & & & & & & +00 \\
\hline 39 & $1.99 \mathrm{E}+05$ & & +00 & $0.00 \mathrm{E}+00$ & 9.58 & $5.64 \mathrm{E}-02$ & 8.93 & & & & & & & & & & & & +01 \\
\hline 40 & & & & & & $1.89 \mathrm{E}-01$ & & & & & & & & & & & & & \\
\hline 41 & $2.51 \mathrm{E}+02$ & 0. & $0.00 \mathrm{E}+00$ & $0.00 \mathrm{E}+00$ & $1.23 \mathrm{E}-02$ & 1.43E-04 & $3.54 \mathrm{E}-03$ & $9.78 \mathrm{E}-06$ & -02 & & & & & 0 & & & & 01 & 05 \\
\hline 42 & & & $=-04$ & & & & & & & & & & & & & & & & \\
\hline 43 & & & & & & & & & & & & & & & & & & & \\
\hline 44 & 0. & & 0 & 0.0 & $0.00 \mathrm{E}+00$ & $0.00 \mathrm{E}+00$ & & -00 & & & & & & & & & & & \\
\hline 45 & & & -00 & & & & & & & & & & & & & & & & \\
\hline 46 & & & & & & & & & & & & & & & & & & & \\
\hline 47 & $9.52 \mathrm{E}+02$ & & 7.11E-03 & $0.00 E+00$ & $0.00 \mathrm{E}+00$ & $1.86 \mathrm{E}-02$ & $0.00 E+00$ & $1.48 \mathrm{E}+00$ & & & & & & & & & & & -08 \\
\hline 48 & 0. & & 0.00 & $0.00 E+00$ & 0.00 & $0.00 \mathrm{E}+00$ & & & & & & & & & & & & & \\
\hline 49 & & & $0.00 \mathrm{E}+00$ & & $0.00 \mathrm{E}+00$ & & & & & & & & & & & & & & \\
\hline 50 & & & $0.00 E+00$ & $0.00 \mathrm{E}+00$ & +00 & +00 & +00 & $E+00$ & & & & 0. & & & & & +00 & & \\
\hline 51 & & & $4.91 \mathrm{E}-04$ & $5.22 \mathrm{E}+00$ & +00 & 3.37E-02 & -02 & $7.74 \mathrm{E}-01$ & & & & & & & & & & & \\
\hline Total & $9.43 \mathrm{E}+05$ & $2.85 \mathrm{E}+00$ & $6.53 \mathrm{E}-01$ & $1.04 \mathrm{E}+02$ & $3.93 \mathrm{E}+01$ & & $4.89 \mathrm{E}+00$ & $6.67 \mathrm{E}+01$ & $7.73 E+01$ & +06 & -04 & 1.7 & 06 & $50 \mathrm{E}+01$ & +04 & 1.6 & $2.11 \mathrm{E}+02$ & $2.21 \mathrm{E}+05$ & $1.76 \mathrm{E}+01$ \\
\hline
\end{tabular}


WSRC-TR-2000-00249

Revision 2

Attachment 3

Americium/Curium Transfer to Tank 51 Sludge Radionuclide Inventory 
Americium/Curium Transfer to Tank 51

Sludge Radionuclide Inventory

\begin{tabular}{|c|c|c|c|c|c|c|c|c|c|}
\hline & & $\begin{array}{c}5 / 1 / 2002 \\
\text { grams }\end{array}$ & $\mathbf{W} / \mathbf{C i}$ & $\mathrm{Ci} / \mathrm{g}$ & $\begin{array}{c}5 / 1 / 2002 \\
\mathrm{Ci}\end{array}$ & $\begin{array}{c}5 / 1 / 2002 \\
\text { grams + 10\% }\end{array}$ & $\begin{array}{c}\text { Final Am/Cm } \\
\text { Transfer } \\
\text { Sludge } \mathbf{C i}\end{array}$ & $\begin{array}{c}\text { Tk } 51 \text { Sludge Ci } \\
\text { WCS Data } \\
\text { Updated } \\
1 / 29 / 03\end{array}$ & $\begin{array}{l}\text { Tk } 51 \text { sludge } \\
\text { after Hot Run } \\
\text { Addition } \\
\text { (Ci) }\end{array}$ \\
\hline Cs & 137 & $1.70 \mathrm{E}+01$ & 0.00101 & 86.98 & $1.48 \mathrm{E}+03$ & $1.87 \mathrm{E}+01$ & $1.63 E+03$ & $1.55 \mathrm{E}+03$ & $3.18 \mathrm{E}+03$ \\
\hline $\mathrm{Ba}$ & $137 \mathrm{~m}$ & $2.58 \mathrm{E}-06$ & $3.94 \mathrm{E}-03$ & $5.38 \mathrm{E}+08$ & $1.39 \mathrm{E}+03$ & $2.84 \mathrm{E}-06$ & $1.53 E+03$ & $1.47 \mathrm{E}+03$ & $3.00 E+03$ \\
\hline $\mathrm{Eu}$ & 154 & $1.96 \mathrm{E}+01$ & 0.009081 & 269.9 & $5.30 \mathrm{E}+03$ & $2.16 \mathrm{E}+01$ & $5.83 E+03$ & $1.08 \mathrm{E}+03$ & $6.91 E+03$ \\
\hline \multirow[t]{3}{*}{ Th } & 230 & $5.55 \mathrm{E}-04$ & 0.02765 & $2.11 \mathrm{E}-02$ & 1.17E-05 & $6.10 \mathrm{E}-04$ & $1.29 \mathrm{E}-05$ & & $1.29 \mathrm{E}-05$ \\
\hline & 231 & $7.54 \mathrm{E}-11$ & 0.00121 & $5.32 \mathrm{E}+05$ & 4.01E-05 & $8.30 \mathrm{E}-11$ & $4.41 \mathrm{E}-05$ & & $4.41 \mathrm{E}-05$ \\
\hline & 234 & $1.35 \mathrm{E}-07$ & 0.000149 & $2.32 \mathrm{E}+04$ & 3.13E-03 & $1.49 \mathrm{E}-07$ & $3.44 \mathrm{E}-03$ & & $3.44 \mathrm{E}-03$ \\
\hline \multirow[t]{4}{*}{$U$} & 234 & $2.83 E+01$ & 0.02829 & $6.25 \mathrm{E}-03$ & 1.77E-01 & $3.12 \mathrm{E}+01$ & $1.95 \mathrm{E}-01$ & $3.47 \mathrm{E}+00$ & $3.67 E+00$ \\
\hline & 235 & $1.86 \mathrm{E}+01$ & 0.02713 & $2.16 \mathrm{E}-06$ & $4.01 \mathrm{E}-05$ & $2.04 \mathrm{E}+01$ & $4.41 \mathrm{E}-05$ & 3.37E-02 & 3.37E-02 \\
\hline & 236 & $5.70 \mathrm{E}+00$ & 0.02662 & $6.47 \mathrm{E}-05$ & 3.69E-04 & $6.27 \mathrm{E}+00$ & $4.06 \mathrm{E}-04$ & 8.84E-02 & 8.88E-02 \\
\hline & 238 & $9.31 \mathrm{E}+03$ & 0.02492 & 3.36E-07 & 3.13E-03 & $2.81 E+06$ & $9.45 \mathrm{E}-01$ & 7.74E-01 & $1.72 \mathrm{E}+00$ \\
\hline \multirow[t]{2}{*}{$\mathrm{Np}$} & 237 & $3.21 \mathrm{E}+01$ & 0.02879 & $7.05 \mathrm{E}-04$ & $2.26 \mathrm{E}-02$ & $3.53 E+01$ & 2.49E-02 & $1.55 \mathrm{E}+00$ & $1.57 \mathrm{E}+00$ \\
\hline & 239 & $8.32 \mathrm{E}-03$ & 0.00253 & $2.32 \mathrm{E}+05$ & $1.93 \mathrm{E}+03$ & $9.15 \mathrm{E}-03$ & $2.12 \mathrm{E}+03$ & & $2.12 \mathrm{E}+03$ \\
\hline \multirow[t]{5}{*}{$\mathrm{Pu}$} & 238 & $1.34 \mathrm{E}+02$ & 0.032593 & 17.12 & $2.30 \mathrm{E}+03$ & $1.48 \mathrm{E}+02$ & $2.53 E+03$ & $1.16 \mathrm{E}+04$ & $1.42 E+04$ \\
\hline & 239 & $6.89 \mathrm{E}+01$ & 3.02E-02 & 0.06216 & $4.28 \mathrm{E}+00$ & $7.57 \mathrm{E}+01$ & $4.71 \mathrm{E}+00$ & $5.17 \mathrm{E}+03$ & $5.18 \mathrm{E}+03$ \\
\hline & 240 & $2.83 E+03$ & $3.06 \mathrm{E}-02$ & 0.2279 & $6.46 \mathrm{E}+02$ & $3.12 E+03$ & $7.11 \mathrm{E}+02$ & $2.13 E+02$ & $9.24 \mathrm{E}+02$ \\
\hline & 241 & $1.00 \mathrm{E}+00$ & $3.20 \mathrm{E}-05$ & 103 & $1.03 E+02$ & $1.10 \mathrm{E}+00$ & $1.13 E+02$ & $2.91 \mathrm{E}+03$ & $3.03 E+03$ \\
\hline & 242 & $1.27 \mathrm{E}+02$ & $2.90 \mathrm{E}-02$ & 0.003818 & 4.83E-01 & $1.39 \mathrm{E}+02$ & 5.31E-01 & 4.46E-01 & $9.77 \mathrm{E}-01$ \\
\hline \multirow[t]{3}{*}{ Am } & 241 & $4.52 \mathrm{E}+02$ & 0.03283 & 3.432 & $1.55 \mathrm{E}+03$ & $4.97 \mathrm{E}+02$ & $1.71 \mathrm{E}+03$ & $9.62 \mathrm{E}+02$ & $2.67 E+03$ \\
\hline & $242 m$ & $1.94 \mathrm{E}+00$ & $4.05 \mathrm{E}-04$ & 9.718 & $1.89 \mathrm{E}+01$ & $2.14 \mathrm{E}+00$ & $2.08 \mathrm{E}+01$ & $6.72 \mathrm{E}-01$ & $2.15 \mathrm{E}+01$ \\
\hline & 243 & $9.68 \mathrm{E}+03$ & 0.031496 & 0.1993 & $1.93 E+03$ & $1.07 \mathrm{E}+04$ & $2.12 \mathrm{E}+03$ & & $2.12 \mathrm{E}+03$ \\
\hline \multirow[t]{4}{*}{$\mathrm{Cm}$} & 244 & $1.85 \mathrm{E}+03$ & 0.03437 & 80.9 & $1.50 \mathrm{E}+05$ & $2.04 \mathrm{E}+03$ & $1.65 \mathrm{E}+05$ & $4.68 \mathrm{E}+02$ & $1.65 \mathrm{E}+05$ \\
\hline & 245 & $9.90 \mathrm{E}+01$ & 0.03329 & 0.1717 & $1.70 \mathrm{E}+01$ & $1.09 \mathrm{E}+02$ & $1.87 \mathrm{E}+01$ & 4.49E-04 & $1.87 \mathrm{E}+01$ \\
\hline & 246 & $8.59 \mathrm{E}+01$ & 0.03192 & 0.3072 & $2.64 \mathrm{E}+01$ & $9.45 \mathrm{E}+01$ & $2.90 \mathrm{E}+01$ & & $2.90 \mathrm{E}+01$ \\
\hline & 247 & $1.39 \mathrm{E}+00$ & 0.03119 & $9.28 \mathrm{E}-05$ & $1.29 \mathrm{E}-04$ & $1.53 E+00$ & $1.42 \mathrm{E}-04$ & & $1.42 \mathrm{E}-04$ \\
\hline \multirow[t]{7}{*}{$\mathrm{Pa}$} & 233 & 1.09E-06 & 2.36E-03 & $2.08 \mathrm{E}+04$ & $2.26 \mathrm{E}-02$ & $1.20 \mathrm{E}-06$ & 2.49E-02 & & $2.49 \mathrm{E}-02$ \\
\hline & $234 \mathrm{~m}$ & $4.56 \mathrm{E}-12$ & $4.95 \mathrm{E}-03$ & $6.87 E+08$ & 3.13E-03 & $5.01 \mathrm{E}-12$ & $3.44 \mathrm{E}-03$ & & $3.44 \mathrm{E}-03$ \\
\hline & 234 & $2.04 \mathrm{E}-12$ & & $2.00 E+06$ & 4.07E-06 & $2.24 \mathrm{E}-12$ & $4.48 \mathrm{E}-06$ & & $4.48 \mathrm{E}-06$ \\
\hline & & & & & $\underset{1.67 \mathrm{E}+05}{\text { Sum }}$ & & $\underset{\substack{\text { Sum } \\
1.83 \mathrm{E}+05}}{ }$ & & \\
\hline & \multicolumn{4}{|c|}{ 1/5/03 wCS Tank 51 Sludge Solids Volume = } & 435,240 & $x 0.2=$ & 87,048 & gal & \\
\hline & \multicolumn{4}{|c|}{ Am/Cm Solution Sludge Solids Volume = } & 30,000 & $x 0.2=$ & 6,000 & gal & \\
\hline & & & & Total $=$ & & & 93,048 & gal & \\
\hline
\end{tabular}


WSRC-TR-2000-00249

Revision 2

Attachment 4

Projected Am/Cm Transfer and Tanks 7 and 18 Combined Contents Transfer to Tank 51 


\begin{tabular}{|c|c|c|c|c|c|c|c|c|}
\hline Radionuclide & $\begin{array}{l}\text { WCS Retr. 2-20-03 } \\
\text { Tank } 51 \text { Prior to } \\
\text { Am/Cm Addition } \\
\text { Sludge } \mathrm{Ci} \\
\text { (Sludge Volume = } \\
435,240 \text { gal } \mathrm{x} \\
0.2=87,048 \text { gal) }\end{array}$ & $\begin{array}{c}\text { Final } \\
\text { Hot Run Ci } \\
\text { (Sludge Volume = } \\
30,000 \text { gal } x \\
0.2=6,000 \text { gal) }\end{array}$ & $\begin{array}{c}\text { Projected } \\
\text { Total Curies of } \\
\text { Radionuclides in } \\
\text { Tank } 51 \text { Sludge } \\
\text { Slurry after } \\
\text { Am/Cm Addition } \\
\text { (Ci) }\end{array}$ & \begin{tabular}{|c|} 
Total \\
Curies of \\
Radionuclides \\
in Tank 7 Sludge \\
(Sludge volume $=$ \\
209,000 gal $x$ \\
$0.3=62,700$ gal) \\
(Ci) \\
\end{tabular} & $\begin{array}{c}\text { Total } \\
\text { Curies of } \\
\text { Radionuclides } \\
\text { in Tank } 18 \text { Sludge } \\
\text { (Sludge volume = } \\
47,000 \text { gal } x \\
0.3=14,100 \text { gal) } \\
\text { (Ci) } \\
\end{array}$ & $\begin{array}{c}\text { Projected } \\
\text { Total Curies of } \\
\text { Radionuclides in } \\
\text { Combined } \\
\text { Tank } 7 \text { and } 18 \\
\text { Sludge Slurry } \\
\text { (Sldg vol. }=76,800 \text { gal) } \\
\text { (Ci) }\end{array}$ & $\begin{array}{c}\text { Projected Total } \\
\text { Curies of } \\
\text { Radionuclides } \\
\text { in Tank } 51 \text { after } \\
\text { Combined Tank } \\
7 \text { and } 18 \text { Addition } \\
\text { (Sldg vol. = } 169,848 \text { gal) } \\
\text { (Ci) }\end{array}$ & $\begin{array}{c}\text { Projected Total } \\
\text { Curies/gal sludge solids } \\
\text { of Radionuclides } \\
\text { in Tank } 51 \text { after Am/Cm } \\
\text { and Combined Tank } \\
7 \text { and } 18 \text { Addition } \\
\text { (Tot. Sldg Solids Vol. } \\
=169,848 \text { gal) }\end{array}$ \\
\hline \multicolumn{9}{|l|}{$\mathrm{H}-3$} \\
\hline C-14 & 5.29E-01 & & $5.29 \mathrm{E}-01$ & 8.62E-01 & 4.01E-02 & $9.02 \mathrm{E}-01$ & $1.43 E+00$ & 8.43E-06 \\
\hline Ni-59 & $7.84 \mathrm{E}+00$ & & $7.84 \mathrm{E}+00$ & $1.87 \mathrm{E}+02$ & $2.36 \mathrm{E}+00$ & $1.90 \mathrm{E}+02$ & $1.97 \mathrm{E}+02$ & $1.16 \mathrm{E}-03$ \\
\hline Co-60 & $6.86 \mathrm{E}+01$ & & $6.86 \mathrm{E}+01$ & $1.51 \mathrm{E}+03$ & $1.26 \mathrm{E}+01$ & $1.52 E+03$ & $1.59 E+03$ & $9.36 \mathrm{E}-03$ \\
\hline $\mathrm{Ni}-63$ & $3.89 \mathrm{E}+00$ & & $3.89 E+00$ & & & & $3.89 E+00$ & $2.29 \mathrm{E}-05$ \\
\hline Se-79 & $1.02 E+01$ & & $1.02 \mathrm{E}+01$ & $1.02 E+02$ & 1.95E-01 & $1.02 E+02$ & $1.12 \mathrm{E}+02$ & $6.61 \mathrm{E}-04$ \\
\hline Sr-90 & $4.69 \mathrm{E}+05$ & & $4.69 \mathrm{E}+05$ & $3.64 \mathrm{E}+06$ & $9.01 E+03$ & $3.65 \mathrm{E}+06$ & $4.12 E+06$ & $2.43 E+01$ \\
\hline Y-90 & $4.69 \mathrm{E}+05$ & & 4.69E+05 & $3.64 \mathrm{E}+06$ & $9.01 E+03$ & $3.65 \mathrm{E}+06$ & $4.12 \mathrm{E}+06$ & $2.43 E+01$ \\
\hline Nb-94 & & & & & & & & \\
\hline TC-99 & $2.25 \mathrm{E}+01$ & & $2.25 E+01$ & $1.76 \mathrm{E}+03$ & $3.38 \mathrm{E}+00$ & $1.77 \mathrm{E}+03$ & $1.79 \mathrm{E}+03$ & $1.05 \mathrm{E}-02$ \\
\hline Ru-106 & $9.11 \mathrm{E}-03$ & & $9.11 \mathrm{E}-03$ & $1.26 \mathrm{E}-04$ & 4.59E-04 & $5.86 \mathrm{E}-04$ & $9.70 \mathrm{E}-03$ & $5.71 \mathrm{E}-08$ \\
\hline Rh-106 & $9.11 E-03$ & & $9.11 E-03$ & $1.26 \mathrm{E}-04$ & 4.59E-04 & $5.86 \mathrm{E}-04$ & $9.70 \mathrm{E}-03$ & $5.71 \mathrm{E}-08$ \\
\hline Sb-125 & $3.44 \mathrm{E}+01$ & & $3.44 E+01$ & $1.12 \mathrm{E}+02$ & $3.80 E+00$ & $1.16 \mathrm{E}+02$ & $1.50 \mathrm{E}+02$ & $8.83 \mathrm{E}-04$ \\
\hline Sn-126 & $4.06 \mathrm{E}+00$ & & $4.06 \mathrm{E}+00$ & $1.90 \mathrm{E}+02$ & 3.62E-01 & $1.90 \mathrm{E}+02$ & $1.94 \mathrm{E}+02$ & $1.14 \mathrm{E}-03$ \\
\hline $1-129$ & $1.31 \mathrm{E}-01$ & & $1.31 \mathrm{E}-01$ & $8.40 \mathrm{E}-03$ & $1.61 \mathrm{E}-05$ & $8.42 \mathrm{E}-03$ & $1.39 \mathrm{E}-01$ & $8.18 \mathrm{E}-07$ \\
\hline Cs-134 & $1.87 \mathrm{E}+00$ & & $1.87 \mathrm{E}+00$ & 1.24E-01 & 1.06E-02 & 1.34E-01 & $2.00 \mathrm{E}+00$ & $1.18 \mathrm{E}-05$ \\
\hline Cs-135 & 8.81E-01 & & 8.81E-01 & $1.18 \mathrm{E}+00$ & $2.26 \mathrm{E}-03$ & $1.18 \mathrm{E}+00$ & $2.06 \mathrm{E}+00$ & $1.21 \mathrm{E}-05$ \\
\hline Cs-137 & $1.55 \mathrm{E}+03$ & $8.14 \mathrm{E}+01$ & $1.63 E+03$ & $2.58 \mathrm{E}+05$ & $6.28 \mathrm{E}+02$ & $2.58 \mathrm{E}+05$ & $2.60 \mathrm{E}+05$ & $1.53 E+00$ \\
\hline Ba-137m & $1.47 \mathrm{E}+03$ & $7.65 \mathrm{E}+01$ & $1.54 \mathrm{E}+03$ & $2.44 \mathrm{E}+05$ & $5.94 \mathrm{E}+02$ & 2.44E+05 & $2.46 \mathrm{E}+05$ & $1.45 \mathrm{E}+00$ \\
\hline Ce-144 & $1.39 \mathrm{E}-03$ & & $1.39 \mathrm{E}-03$ & $2.45 \mathrm{E}-07$ & $8.20 \mathrm{E}-06$ & $8.44 \mathrm{E}-06$ & $1.40 \mathrm{E}-03$ & $8.23 \mathrm{E}-09$ \\
\hline Pr-144 & $1.39 \mathrm{E}-03$ & & $1.39 \mathrm{E}-03$ & $2.45 \mathrm{E}-07$ & $8.20 \mathrm{E}-06$ & 8.44E-06 & $1.40 \mathrm{E}-03$ & $8.23 \mathrm{E}-09$ \\
\hline Pm-147 & $8.64 \mathrm{E}+02$ & & $8.64 \mathrm{E}+02$ & $1.58 \mathrm{E}+03$ & $6.06 \mathrm{E}+01$ & $1.64 \mathrm{E}+03$ & $2.51 E+03$ & $1.48 \mathrm{E}-02$ \\
\hline Eu-154 & $1.08 \mathrm{E}+03$ & $5.83 E+03$ & $6.91 \mathrm{E}+03$ & $6.53 E+03$ & $2.95 E+01$ & $6.56 \mathrm{E}+03$ & $1.35 E+04$ & 7.93E-02 \\
\hline Th-230 & & $1.29 \mathrm{E}-05$ & 1.29E-05 & & & & $1.29 \mathrm{E}-05$ & $7.58 \mathrm{E}-11$ \\
\hline Th-231 & & 4.41E-05 & 4.41E-05 & & & & 4.41E-05 & 2.60E-10 \\
\hline Th-232 & $5.48 \mathrm{E}-02$ & & $5.48 \mathrm{E}-02$ & & & & $5.48 \mathrm{E}-02$ & $3.22 \mathrm{E}-07$ \\
\hline Th-234 & & $3.44 \mathrm{E}-03$ & 3.44E-03 & & & & $3.44 \mathrm{E}-03$ & 2.03E-08 \\
\hline U-232 & 4.91E-04 & & 4.91E-04 & 8.59E-02 & $5.66 \mathrm{E}-04$ & 8.64E-02 & $8.69 \mathrm{E}-02$ & $5.12 \mathrm{E}-07$ \\
\hline U-233 & $5.22 \mathrm{E}+00$ & & $5.22 \mathrm{E}+00$ & & & & $5.22 \mathrm{E}+00$ & $3.08 \mathrm{E}-05$ \\
\hline U-234 & $3.47 \mathrm{E}+00$ & $1.95 \mathrm{E}-01$ & $3.67 \mathrm{E}+00$ & & & & $3.67 \mathrm{E}+00$ & $2.16 \mathrm{E}-05$ \\
\hline U-235 & 3.37E-02 & 4.41E-05 & 3.37E-02 & 3.79E-01 & 4.30E-03 & 3.84E-01 & 4.17E-01 & $2.46 \mathrm{E}-06$ \\
\hline U-236 & 8.84E-02 & 4.06E-04 & $8.88 \mathrm{E}-02$ & & & & 8.88E-02 & $5.23 \mathrm{E}-07$ \\
\hline U-238 & 7.74E-01 & $9.45 \mathrm{E}-01$ & $1.72 \mathrm{E}+00$ & $9.16 \mathrm{E}+00$ & 2.31E-01 & $9.39 \mathrm{E}+00$ & $1.11 \mathrm{E}+01$ & $6.54 \mathrm{E}-05$ \\
\hline $\mathrm{Pa}-233$ & & $2.49 \mathrm{E}-02$ & $2.49 \mathrm{E}-02$ & & & & $2.49 \mathrm{E}-02$ & 1.46E-07 \\
\hline $\mathrm{Pa}-234 \mathrm{~m}$ & & $3.44 \mathrm{E}-03$ & $3.44 \mathrm{E}-03$ & & & & $3.44 \mathrm{E}-03$ & 2.03E-08 \\
\hline Pa-234 & & $4.48 \mathrm{E}-06$ & 4.48E-06 & & & & $4.48 \mathrm{E}-06$ & $2.64 \mathrm{E}-11$ \\
\hline Np-237 & $1.55 \mathrm{E}+00$ & $2.49 \mathrm{E}-02$ & $1.57 E+00$ & $8.40 \mathrm{E}+00$ & & $8.40 E+00$ & $9.97 \mathrm{E}+00$ & $5.87 \mathrm{E}-05$ \\
\hline Np-239 & & $2.12 E+03$ & $2.12 E+03$ & & & & $2.12 \mathrm{E}+03$ & $1.25 \mathrm{E}-02$ \\
\hline Pu-238 & $1.16 \mathrm{E}+04$ & $2.53 \mathrm{E}+03$ & $1.42 \mathrm{E}+04$ & $2.43 \mathrm{E}+04$ & $9.85 \mathrm{E}+02$ & $2.53 E+04$ & $3.94 \mathrm{E}+04$ & $2.32 \mathrm{E}-01$ \\
\hline Pu-239 & $5.17 \mathrm{E}+03$ & $4.71 E+00$ & $5.18 \mathrm{E}+03$ & $3.67 \mathrm{E}+03$ & $1.41 \mathrm{E}+02$ & $3.81 E+03$ & $8.99 E+03$ & $5.29 \mathrm{E}-02$ \\
\hline Pu-240 & $2.13 E+02$ & $7.11 E+02$ & $9.24 \mathrm{E}+02$ & $8.76 \mathrm{E}+02$ & $3.60 \mathrm{E}+01$ & $9.12 E+02$ & $1.84 E+03$ & $1.08 \mathrm{E}-02$ \\
\hline Pu-241 & $2.91 E+03$ & $1.13 E+02$ & $3.03 E+03$ & $7.12 E+03$ & $6.58 \mathrm{E}+02$ & $7.78 \mathrm{E}+03$ & $1.08 \mathrm{E}+04$ & $6.36 \mathrm{E}-02$ \\
\hline Pu-242 & 4.46E-01 & $5.31 \mathrm{E}-01$ & $9.77 \mathrm{E}-01$ & $2.82 \mathrm{E}-01$ & $4.61 \mathrm{E}-02$ & 3.28E-01 & $1.31 \mathrm{E}+00$ & $7.69 \mathrm{E}-06$ \\
\hline Am-241 & $9.62 E+02$ & $1.71 \mathrm{E}+03$ & $2.67 \mathrm{E}+03$ & $1.40 \mathrm{E}+04$ & 7.12E+01 & $1.41 \mathrm{E}+04$ & $1.67 \mathrm{E}+04$ & $9.85 \mathrm{E}-02$ \\
\hline$A m-242 m$ & $6.72 \mathrm{E}-01$ & $2.08 \mathrm{E}+01$ & $2.15 \mathrm{E}+01$ & $1.59 \mathrm{E}+01$ & & $1.59 \mathrm{E}+01$ & $3.74 E+01$ & $2.20 \mathrm{E}-04$ \\
\hline Am-243 & & $2.12 E+03$ & $2.12 \mathrm{E}+03$ & & & & $2.12 E+03$ & $1.25 \mathrm{E}-02$ \\
\hline $\mathrm{Cm}-244$ & $4.68 \mathrm{E}+02$ & $1.65 E+05$ & $1.65 \mathrm{E}+05$ & $2.50 \mathrm{E}+00$ & 7.14E-03 & $2.51 \mathrm{E}+00$ & $1.65 E+05$ & $9.74 \mathrm{E}-01$ \\
\hline $\mathrm{Cm}-245$ & 4.49E-04 & $1.87 \mathrm{E}+01$ & $1.87 \mathrm{E}+01$ & $2.90 \mathrm{E}-06$ & $5.60 \mathrm{E}-09$ & $2.90 \mathrm{E}-06$ & $1.87 \mathrm{E}+01$ & $1.10 \mathrm{E}-04$ \\
\hline $\mathrm{Cm}-246$ & & $2.90 \mathrm{E}+01$ & $2.90 E+01$ & & & & $2.90 \mathrm{E}+01$ & $1.71 \mathrm{E}-04$ \\
\hline $\mathrm{Cm}-247$ & & $1.42 \mathrm{E}-04$ & $1.42 \mathrm{E}-04$ & & & & $1.42 \mathrm{E}-04$ & $\underline{8.35 \mathrm{E}-10}$ \\
\hline Total & $9.64 E+05$ & $\overline{1.80 \mathrm{E}+05}$ & $1.14 \mathrm{E}+06$ & $7.85 \mathrm{E}+06$ & $2.12 E+04$ & $7.87 \mathrm{E}+06$ & $\overline{9.01 \mathrm{E}+06}$ & $\overline{5.31 \mathrm{E}+01}$ \\
\hline
\end{tabular}


WSRC-TR-2000-00249

Revision 2

Attachment 5

Calculation of H-Area Tank Farm Scaling Factors from WCS Radionuclide Inventory Data 


\begin{tabular}{|c|c|c|c|c|c|c|c|c|c|c|c|c|c|c|c|c|c|c|c|c|c|c|c|c|c|c|}
\hline \multicolumn{2}{|c|}{$\begin{array}{c}\text { Tank } \quad \mathrm{H}-3 \\
\text { Tank Inventory } \\
\text { (Ci) }\end{array}$} & $C-14$ & Ni-59 & Co-60 & $\mathrm{Ni}-63$ & Se-79 & Sr-90 & $Y-90$ & $\mathrm{Nb}-94$ & Tc-99 & Ru-106 & Rh-106 & Sb-125 & Sn-126 & I-129 & Cs-134 & Cs-135 & Cs-137 & Ba-137m & Ce-144 & Pr-144 & Pm-147 & Eu-154 & Th-232 & $\mathrm{U}-232$ & $\mathrm{U}-233$ \\
\hline \multirow{2}{*}{\multicolumn{2}{|c|}{$\begin{array}{l}9 \\
10\end{array}$}} & $3.09 \mathrm{E}-03$ & $3.64 \mathrm{E}+00$ & $2.07 E+01$ & & $2.49 \mathrm{E}+00$ & $8.17 E+04$ & $8.17 \mathrm{E}+04$ & & $4.31 \mathrm{E}+01$ & $1.96 \mathrm{E}-08$ & $1.96 \mathrm{E}-08$ & $6.99 \mathrm{E}-01$ & $4.63 \mathrm{E}+00$ & $2.05 \mathrm{E}-04$ & 4.14E- -04 & 2. & 5.8 & $5.49 \mathrm{E}+03$ & 4.74 & 4. & $9.18 \mathrm{E}$ & $1.17 \mathrm{E}+02$ & & 1.87E-03 & \\
\hline & & 3.24E-04 & 3.81E-01 & 2. $46 \mathrm{E}+00$ & & 2.60E-01 & $8.73 E+03$ & $8.73 E+03$ & & 4.49E +00 & $3.81 \mathrm{E}-09$ & $3.81 E-09$ & $8.82 \mathrm{E}-02$ & $4.78 \mathrm{E}-01$ & $2.13 \mathrm{E}-05$ & $7.32 \mathrm{E}-05$ & $3.01 \mathrm{E}-03$ & $6.16 \mathrm{E}+02$ & $5.83 \mathrm{E}+02$ & $1.36 \mathrm{E}-12$ & $1.36 \mathrm{E}-12$ & $1.18 \mathrm{E}+00$ & $1.38 \mathrm{E}+01$ & & $1.92 \mathrm{E}-04$ & \\
\hline \multicolumn{2}{|l|}{11} & 1.59E-01 & $1.64 \mathrm{E}+02$ & $1.33 \mathrm{E}+04$ & & $9.05 \mathrm{E}+01$ & $5.42 \mathrm{E}+06$ & $5.42 E+06$ & & $1.53 \mathrm{E}+03$ & $1.41 \mathrm{E}-01$ & $1.41 \mathrm{E}-01$ & $7.88 \mathrm{E}+02$ & $8.29 \mathrm{E}+01$ & $5.31 \mathrm{E}-03$ & $4.52 \mathrm{E}+01$ & 1.03E+00 & $2.98 \mathrm{E}+05$ & $2.82 E+05$ & 2.19E-02 & 2.19E-02 & $2.05 E+04$ & 9E+04 & 2 & $1.66 \mathrm{E}-04$ & 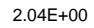 \\
\hline \multirow{2}{*}{\multicolumn{2}{|c|}{$\begin{array}{l}12 \\
13\end{array}$}} & 2.53E-01 & $2.80 \mathrm{E}+02$ & 1.32E+04 & & $1.58 \mathrm{E}+02$ & $8.37 \mathrm{E}+06$ & $8.37 \mathrm{E}+06$ & & $2.68 \mathrm{E}+03$ & $6.31 \mathrm{E}-03$ & $6.31 \mathrm{E}-03$ & 4.56E+02 & $1.62 E+02$ & $9.69 \mathrm{E}-03$ & $1.72 \mathrm{E}+01$ & $1.79 E+00$ & $4.71 \mathrm{E}+05$ & $4.46 \mathrm{E}+05$ & $1.95 \mathrm{E}-04$ & $1.95 \mathrm{E}-04$ & 1.12E+04 & $7.18 \mathrm{E}+04$ & 1. $.36 \mathrm{E}+00$ & $1.41 \mathrm{E}-02$ & $3 E+01$ \\
\hline \multirow{2}{*}{\multicolumn{2}{|c|}{$\begin{array}{l}13 \\
14\end{array}$}} & $2.92 \mathrm{E}-01$ & $2.78 \mathrm{E}+02$ & $7.46 \mathrm{E}+03$ & & $1.72 \mathrm{E}+02$ & $7.70 E+06$ & $7.70 \mathrm{E}+06$ & & $2.93 \mathrm{E}+03$ & 3.17E-03 & 3.17E-03 & $2.48 \mathrm{E}+02$ & $2.25 \mathrm{E}+02$ & 1.18E-02 & $8.08 \mathrm{E}+00$ & $1.96 \mathrm{E}+00$ & 4.64E+05 & $4.38 \mathrm{E}+05$ & $1.10 \mathrm{E}-04$ & $1.10 \mathrm{E}-04$ & $5.79 E+03$ & $4.71 \mathrm{E}+04$ & $1.98 \mathrm{E}-01$ & $5.54 \mathrm{E}-02$ & 4.06E+01 \\
\hline & & $1.51 \mathrm{E}-03$ & $7.72 \mathrm{E}+00$ & $8.40 \mathrm{E}+01$ & & $5.26 \mathrm{E}+00$ & $1.96 \mathrm{E}+05$ & 1.96E+05 & & $9.06 \mathrm{E}+01$ & $4.33 \mathrm{E}-07$ & $4.33 \mathrm{E}-07$ & $2.88 \mathrm{E}+00$ & $8.82 \mathrm{E}+00$ & $4.09 \mathrm{E}-04$ & $1.03 \mathrm{E}-02$ & 5.06E-02 & $1.32 \mathrm{E}+04$ & 1. $25 \mathrm{E}+04$ & $1.39 \mathrm{E}-09$ & $1.39 \mathrm{E}-09$ & $4.30 \mathrm{E}+01$ & $5.31 \mathrm{E}+02$ & $1.06 \mathrm{E}-02$ & $3.22 \mathrm{E}-03$ & 3.74E-01 \\
\hline \multicolumn{2}{|l|}{15} & $2.34 \mathrm{E}-01$ & $2.60 \mathrm{E}+02$ & $1.01 \mathrm{E}+04$ & & $1.44 \mathrm{E}+02$ & $7.50 \mathrm{E}+06$ & $7.50 E+06$ & & $2.44 \mathrm{E}+03$ & $1.01 \mathrm{E}-02$ & $1.01 \mathrm{E}-02$ & $3.01 \mathrm{E}+02$ & $1.32 \mathrm{E}+02$ & $8.43 \mathrm{E}-03$ & 1.10E+01 & 1.63E+00 & 4.15E+05 & $3.93 E+05$ & 1.34E-03 & $1.34 \mathrm{E}-03$ & $7.41 \mathrm{E}+03$ & $6.08 \mathrm{E}+04$ & 1. $13 \mathrm{E}+00$ & & 1.39E+01 \\
\hline \multirow{2}{*}{\multicolumn{2}{|c|}{$\begin{array}{l}21 \\
22\end{array}$}} & $8.96 \mathrm{E}-05$ & 1.04E+00 & $1.89 \mathrm{E}+02$ & & $7.82 \mathrm{E}-01$ & $5.37 \mathrm{E}+04$ & $5.37 \mathrm{E}+04$ & & $1.32 \mathrm{E}+01$ & 1.23E-02 & 1.23E-02 & $2.48 \mathrm{E}+01$ & $7.15 \mathrm{E}-01$ & $4.58 \mathrm{E}-05$ & $1.96 \mathrm{E}+00$ & $8.84 \mathrm{E}-03$ & $2.92 \mathrm{E}+03$ & $2.76 \mathrm{E}+03$ & $1.97 \mathrm{E}-03$ & $1.97 \mathrm{E}-03$ & $6.73 \mathrm{E}+02$ & $8.04 \mathrm{E}+02$ & $5.67 \mathrm{E}-06$ & & \\
\hline & & & 2.13E+00 & $\begin{array}{l}3.70 \mathrm{E}+02 \\
526 \mathrm{E}-01\end{array}$ & & $1.66 \mathrm{E}+00$ & $1.14 \mathrm{E}+05$ & 1.14E+05 & & $2.80 \mathrm{E}+01$ & $1.48 \mathrm{E}-02$ & $1.48 \mathrm{E}-02$ & $4.30 \mathrm{E}+01$ & $1.51 \mathrm{E}+00$ & $9.70 \mathrm{E}-05$ & $\begin{array}{l}3.14 \\
.71\end{array}$ & $1.87 \mathrm{E}-02$ & & 03 & $2.07 E-03$ & $2.07 \mathrm{E}-03$ & 1.16E+03 & $1.65 \mathrm{E}+03$ & & & $7 E+00$ \\
\hline \multicolumn{2}{|l|}{$\begin{array}{l}23 \\
30\end{array}$} & $7.80 \mathrm{E}-04$ & $8.56 \mathrm{E}-01$ & $\begin{array}{l}5.26 \mathrm{E}-01 \\
4.52 \mathrm{E}+02\end{array}$ & & $4.71 \mathrm{E}-01$ & $4.06 E+04$ & 4.06E +04 & & $7.98 \mathrm{E}+00$ & $1.15 E+00$ & 1.15E+00 & 1.22E+02 & $4.31 \mathrm{E}-01$ & $276 \mathrm{E}-05$ & $\begin{array}{l}2.711 \mathrm{E}-02 \\
176+01\end{array}$ & $5.33 \mathrm{E}-03$ & $\begin{array}{l}4.49 \mathrm{E}+02 \\
2.19 \mathrm{E}+03\end{array}$ & $\begin{array}{l}4.25+25+02 \\
2.07 \mathrm{E}+03\end{array}$ & $6.98 \mathrm{E}-01$ & $6.98 \mathrm{E}-01$ & $3.58 \mathrm{E}+03$ & $9.82 \mathrm{E}+02$ & & & \\
\hline \multicolumn{2}{|l|}{$\begin{array}{l}30 \\
32\end{array}$} & $2.45 \mathrm{E}-01$ & $2.71 E+02$ & 4. $98 \mathrm{E}+04$ & & $1.49 \mathrm{E}+02$ & $1.02 \mathrm{E}+07$ & $1.02 E+07$ & & $3 \mathrm{E}+03$ & $30 \mathrm{E}+01$ & $7.30 \mathrm{E}+01$ & $8.19 \mathrm{E}+03$ & $1.37 E+02$ & $8.75 \mathrm{E}-03$ & $1.04 \mathrm{E}+03$ & $1.69 \mathrm{E}+00$ & $5.56 \mathrm{E}+05$ & $5.26 \mathrm{E}+05$ & $5.16 \mathrm{E}+01$ & $5.16 \mathrm{E}+01$ & $2.35 \mathrm{E}+05$ & $1.55 \mathrm{E}+05$ & & & \\
\hline \multirow{2}{*}{\multicolumn{2}{|c|}{$\begin{array}{l}35 \\
36\end{array}$}} & $2.07 \mathrm{E}-01$ & $2.27 \mathrm{E}+02$ & $5.88 \mathrm{E}+04$ & & $1.25 \mathrm{E}+02$ & $9.31 E+06$ & $9.31 \mathrm{E}+06$ & & $2.12 \mathrm{E}+03$ & 1.14E+02 & 1.14E+02 & $1.02 E+04$ & $1.14 \mathrm{E}+02$ & 7.32E-03 & $1.28 \mathrm{E}+03$ & $1.41 \mathrm{E}+00$ & $5.05 \mathrm{E}+05$ & $4.78 \mathrm{E}+05$ & $1.11 \mathrm{E}+02$ & $1.11 \mathrm{E}+02$ & $2.94 \mathrm{E}+05$ & $1.66 \mathrm{E}+00$ & & & \\
\hline & & $2.34 \mathrm{E}-04$ & $2.57 \mathrm{E}-01$ & 4.84E+01 & & $1.41 \mathrm{E}-01$ & $1.01 \mathrm{E}+04$ & $1.01 \mathrm{E}+04$ & & $2.39 \mathrm{E}+00$ & 1.69E-03 & 1.69E-03 & $5.00 \mathrm{E}+00$ & $1.29 \mathrm{E}-01$ & $8.28 \mathrm{E}-06$ & 3.80E-01 & $1.60 \mathrm{E}-03$ & $5.48 \mathrm{E}+02$ & $5.18 \mathrm{E}+02$ & 1.99E-04 & $1.99 \mathrm{E}-04$ & $1.35 \mathrm{E}+02$ & $1.59 \mathrm{E}+02$ & & & \\
\hline \multicolumn{2}{|l|}{39} & $1.81 \mathrm{E}-01$ & $1.98 \mathrm{E}+02$ & $8.46 \mathrm{E}+04$ & & $1.09 \mathrm{E}+02$ & $9.01 \mathrm{E}+06$ & $9.01 E+06$ & & $1.85 \mathrm{E}+03$ & $2.06 \mathrm{E}+02$ & $2.06 \mathrm{E}+02$ & $1.97 \mathrm{E}+04$ & $9.98 \mathrm{E}+01$ & $6.39 \mathrm{E}-03$ & $2.67 E+03$ & $1.23 \mathrm{E}+00$ & $4.86 \mathrm{E}+05$ & $4.60 \mathrm{E}+05$ & $2.13 \mathrm{E}+02$ & $2.13 \mathrm{E}+02$ & $5.72 \mathrm{E}+05$ & $1.99 \mathrm{E}+05$ & & & \\
\hline \multirow{2}{*}{\multicolumn{2}{|c|}{$\begin{array}{l}40 \\
42\end{array}$}} & $6.14 \mathrm{E}-01$ & 1.43E+02 & $5.05 E+03$ & & $7.90 E+01$ & 3.67E+06 & $3.67 E+06$ & & $1.36 \mathrm{E}+03$ & $1.73 \mathrm{E}-01$ & & $1.24 \mathrm{E}+03$ & $1.41 \mathrm{E}+02$ & $6.36 \mathrm{E}-03$ & $8.12 \mathrm{E}+00$ & & & $2.37 \mathrm{E}+05$ & $7.75 \mathrm{E}-03$ & $7.75 \mathrm{E}-03$ & $2.03 E+04$ & $1.44 \mathrm{E}+04$ & $2.90 \mathrm{E}-02$ & $6.72 \mathrm{E}-02$ & $1.84 \mathrm{E}+00$ \\
\hline & & $2.57 \mathrm{E}-02$ & $\begin{array}{l}\text { 1. } 15 \mathrm{E}+01 \\
144 \mathrm{~F}\end{array}$ & $\begin{array}{l}4.83 \mathrm{E}+02 \\
801\end{array}$ & & $\begin{array}{l}5.97 \mathrm{E}+00 \\
1\end{array}$ & $\begin{array}{l}3.17 E+05 \\
\end{array}$ & $\begin{array}{l}3.17 E+05 \\
0\end{array}$ & & $1.01 \mathrm{E}+02$ & 6.33E-03 & 6.33E-03 & 2.47E+01 & $5.54 \mathrm{E}+00$ & 3.52E-04 & $\begin{array}{l}1.35 \mathrm{E}+00 \\
\end{array}$ & 6.77E-02 & $\begin{array}{l}1.76 \mathrm{E}+04 \\
5\end{array}$ & 1.66E+04 & $\begin{array}{l}9.78 \mathrm{E}-04 \\
1\end{array}$ & $9.78 \mathrm{E}-04$ & $6.24 \mathrm{E}+02$ & $2.73 E+03$ & $4.36 \mathrm{E}-02$ & $2.35 \mathrm{E}-04$ & $6.14 \mathrm{E}-01$ \\
\hline \multirow{2}{*}{\multicolumn{2}{|c|}{$\begin{array}{l}43 \\
{ }_{5} 51\end{array}$}} & 1.43E+ & $\begin{array}{l}1.444+01 \\
1.97 \mathrm{E}+02\end{array}$ & $\begin{array}{l}8.01 E+03 \\
159 \mathrm{E}+03\end{array}$ & & $\begin{array}{l}1.12 E+01 \\
1.12 E+02\end{array}$ & $\begin{array}{r}9.49 E+05 \\
412 F\end{array}$ & $\begin{array}{l}9.49 E+05 \\
412+06\end{array}$ & & $\begin{array}{r}1.89 \mathrm{E}+02 \\
1.79 \mathrm{E}\end{array}$ & $8.35 \mathrm{E}+01$ & $\begin{array}{l}8.35 \mathrm{E}+01 \\
0\end{array}$ & $\begin{array}{l}2.91 E+03 \\
150\end{array}$ & $\begin{array}{l}1.02 \mathrm{E}+01 \\
\end{array}$ & $\begin{array}{l}6.56 \mathrm{E}-04 \\
1\end{array}$ & $\begin{array}{l}4.71 E+02 \\
\text { 2 }\end{array}$ & $\begin{array}{l}1.27 \mathrm{E}-01 \\
\end{array}$ & $\begin{array}{l}5.09 \mathrm{E}+04 \\
\end{array}$ & $\begin{array}{l}4.82 E+04 \\
247\end{array}$ & $\begin{array}{l}1.25 \mathrm{E}+02 \\
1\end{array}$ & $\begin{array}{l}1.25 \mathrm{E}+02 \\
\end{array}$ & $8.64 \mathrm{E}+04$ & 2.23E+04 & 195 & $869 E-0 ?$ & 525 \\
\hline & & $1.405+00$ & 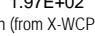 & 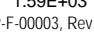 & $\begin{array}{l}3.89 \\
\text {. a) and }\end{array}$ & $\begin{array}{l}1.12 \mathrm{EE}+02 \\
7 \mathrm{7} \text { procted }\end{array}$ & $\begin{array}{l}4.12 \mathrm{E}+06 \\
\text { ranster. }\end{array}$ & & & & & & & $1.94 \mathrm{E}+02$ & & & $2.06 \mathrm{E}+00$ & $2.61 E+05$ & & & & & $1.35 E+04$ & 5.48E & $8.69 \mathrm{E}-02$ & $22 \mathrm{E}-\mathrm{T}$ \\
\hline \multicolumn{2}{|l|}{$\begin{array}{l}\text { Average } \\
\text { Mod. Av. } \\
\text { (Att. 6) }\end{array}$} & 2.28E-01 & $1.14 \mathrm{E}+02$ & 1.33E+04 & $3.89 \mathrm{E}+00$ & $6.48 \mathrm{E}+01$ & $3.73 E+06$ & $3.73 E+06$ & & $1.10 \mathrm{E}+03$ & $2.66 \mathrm{E}+01$ & $2.66 \mathrm{E}+01$ & $2.47 \mathrm{E}+03$ & $7.33 \mathrm{E}+01$ & $\begin{array}{l}1.14 \mathrm{E}-02 \\
1.32 \mathrm{E}-02\end{array}$ & $2.94 \mathrm{E}+02$ & $7.80 \mathrm{E}-01$ & $2.00 \mathrm{E}+05$ & $1.90 \mathrm{E}+05$ & $2.78 \mathrm{E}+01$ & $2.78 \mathrm{E}+01$ & $7.01 \mathrm{E}+04$ & $4.54 \mathrm{E}+04$ & $3.16 \mathrm{E}-01$ & $2.55 \mathrm{E}-02$ & $1.04 \mathrm{E}$ \\
\hline \multicolumn{27}{|c|}{$1125 \Omega 413$} \\
\hline & $3.78 \mathrm{E}-08$ & $\mathrm{E}-05$ & $3 \mathrm{E}-04$ & & 5 & OE- & $00 E+00$ & & $E-04$ & $0 E-13$ & $40 \mathrm{E}$ & $8.56 \mathrm{E}-06$ & 5 & & 5.06E-09 & $3.53 E-07$ & $7.11 \mathrm{E}-02$ & 6.7 & 5.8 & 5.8 & 04 & 1. & & $2.28 \mathrm{E}-08$ & \\
\hline$T$ & & $3.71 \mathrm{E}-08$ & $\mathrm{E}-05$ & $2.82 \mathrm{E}-04$ & & & 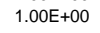 & 00 & & Fo4 & $6 \mathrm{E}-13$ & $.36 \mathrm{E}-13$ & 1.0 & & 9 & 8.3 & & 7.06E-02 & $6.68 \mathrm{E}-02$ & 1.56E-16 & $1.56 \mathrm{E}-16$ & $1.35 \mathrm{E}-04$ & $1.58 \mathrm{E}-03$ & & $2.20 \mathrm{E}-08$ & \\
\hline 11 & & 2. & 5 & 2.45 & & 5 & 1.0 & 1.00E+00 & & 04 & 08 & 2.66 & 04 & 1. & & 06 & & 5.4 & 5.1 & 4.03E-09 & & $3.79 \mathrm{E}-03$ & & & & \\
\hline 12 & & & & & & & & & & & & & & & & & & & & & & & & & & \\
\hline 13 & & 3.8 & 3.6 & $9.70 \mathrm{E}$ & & 2 & $1.00 \mathrm{E}$ & 1.0 & & 3 & 10 & 4.1 & & & & 1. & & & & $1.4 \mathrm{Y}-\mathrm{l}$ & & 7.5 & & & $7.20 \mathrm{E}-09$ & 5.2 \\
\hline 14 & & & 3. & 4.2 & & & $1.00 \mathrm{E}$ & & & & & & & & & & & & & & & & & & $1.64 \mathrm{E}-08$ & \\
\hline 15 & & & $3.47 \mathrm{E}-05$ & $1.35 \mathrm{E}$ & & & $1.00 \mathrm{E}$ & 1.00 & & 04 & 1.35 & 1.35 & & & & & & $5.53 \mathrm{E}-02$ & & & & & & & & \\
\hline 21 & & 1.67E- 09 & & 3.53! & & 1. & $1.00 \mathrm{E} \quad \mathrm{C}$ & & & 2.46E-04 & $2.28 \mathrm{E}-07$ & 2.28E-07 & 4.61E-04 & $1.33 \mathrm{E}-05$ & & 3.64E- 05 & 1.64E- -07 & 5.43 & $5.14 \mathrm{E}-02$ & $3.66 \mathrm{E}-08$ & 3.6 & $1.25 \mathrm{E}-02$ & & $1.05 \mathrm{E}-10$ & & \\
\hline 22 & & & $1.88 \mathrm{E}-05$ & 3.26E- 03 & & $1.46 \mathrm{E}-05$ & $1.00 \mathrm{E}+00$ & $1.00 \mathrm{E}+00$ & & $2.47 \mathrm{E}-04$ & 1.30E-07 & $1.30 \mathrm{E}-07$ & -04 & $1.33 \mathrm{E}-05$ & $8.54 \mathrm{E}-$ & $2.76 \mathrm{E}-05$ & $1.65 \mathrm{E}-07$ & $5.43 \mathrm{E}-02$ & $5.14 \mathrm{E}-02$ & 1.82E-08 & $1.82 \mathrm{E}-08$ & $1.02 \mathrm{E}-02$ & $1.45 \mathrm{E}-02$ & & & $\begin{array}{l}3.2<\mathrm{E}-00 \\
9.46 \mathrm{E}-06\end{array}$ \\
\hline $\begin{array}{l}23 \\
30\end{array}$ & & $1.9>>$ & 2.1 & & & & & & & & & & & & & & & & & & & & & & & \\
\hline 32 & & & & & & & & & & & & & & & & & & & & & & & & & & \\
\hline 35 & & & & & & & & & & & & & & & & & & & & & & & & & & \\
\hline 36 & & & & & & & & & & & & & & & & & & & & & & & & & & \\
\hline 39 & & & & & & & & & & & & & & & & & & & & & & & & & & \\
\hline 40 & & 1.67 & $3.90>0$ & $138 \mathrm{E}$ & & 5 & 10 & $1.00 \mathrm{E}$ & & $\begin{array}{l}2.072 E-04 \\
3.725\end{array}$ & 4.72 & 4.72 & 3.37 & 3.85 & $\begin{array}{l}1.09 \\
1.74\end{array}$ & $\begin{array}{l}2.96 \\
2.2\end{array}$ & $2.49 \mathrm{E}-07$ & $\begin{array}{l}5.39 \\
6.83\end{array}$ & $\begin{array}{l}5.10 \mathrm{E}-02 \\
6.46 \mathrm{E}-02\end{array}$ & $\begin{array}{l}2.30 E-05 \\
2.11 E-09\end{array}$ & $2.11 \mathrm{E}-09$ & $\begin{array}{l}0.35 \mathrm{E}-02 \\
5.53 \mathrm{E}-03\end{array}$ & $\begin{array}{l}2.21 \mathrm{E}-02 \\
3.93 \mathrm{E}-03\end{array}$ & $7.92 \mathrm{E}-09$ & 18 & 5.0 \\
\hline 42 & & $8.12 \mathrm{E}-08$ & 3.6 & 1.52 & & 1.8 & 1.00 & 1.00 & & 4 & 1.9 & 1.95 & 7.77 & 1.7 & 1. & 4. & 2.13 & $5.54 \mathrm{E}-02$ & $5.24 \mathrm{E}-02$ & $3.08 \mathrm{E}-09$ & $\begin{array}{l}3.08 \mathrm{E}-09 \\
\end{array}$ & $1.97 \mathrm{E}-03$ & $8.59 \mathrm{E}-03$ & $1.37 \mathrm{E}-07$ & $7.40 \mathrm{E}-10$ & $1.94 \mathrm{E}-06$ \\
\hline 43 & & & $1.52 \mathrm{E}-05$ & 8.4 & & $1.18 \mathrm{E}-05$ & 1.00E+00 & & & 04 & & 8.80 & 3.06 & 1.08 & & & 1.3 & & $5.08 \mathrm{E}-02$ & $1.31 \mathrm{E}-04$ & $1.31 \mathrm{E}-04$ & $9.10 \mathrm{E}-02$ & $2.35 \mathrm{E}-02$ & & & \\
\hline 51 & & $3.47 \mathrm{E}-07$ & $4.79 \mathrm{E}-05$ & 3.86E-04 & $9.44 \mathrm{E}-07$ & $2.72 \mathrm{E}-05$ & $1.00 \mathrm{E}+00$ & $1.00 \mathrm{E}+00$ & & $4.34 \mathrm{E}-04$ & $2.35 \mathrm{E}-09$ & $2.35 \mathrm{E}-09$ & 3.64E-05 & $4.71 \mathrm{E}-05$ & 3.37E-08 & $4.85 \mathrm{E}-07$ & $5.01 \mathrm{E}-07$ & $6.35 \mathrm{E}-02$ & $6.00 \mathrm{E}-02$ & 3.39E-10 & 3.39E-10 & $6.08 \mathrm{E}-04$ & $3.27 \mathrm{E}-03$ & $1.33 \mathrm{E}-08$ & 2.11E-08 & $1.27 \mathrm{E}-06$ \\
\hline $\begin{array}{l}\text { Average } \\
\text { Mod. Av. }\end{array}$ & & $5.73 \mathrm{E}-08$ & $3.10 \mathrm{E}-05$ & $3.46 \mathrm{E}-03$ & $9.44 \mathrm{E}-07$ & $1.88 \mathrm{E}-05$ & $1.00 \mathrm{E}+00$ & $1.00 E+00$ & & $3.19 \mathrm{E}-04$ & $8.85 \mathrm{E}-06$ & $85 E-06$ & $6.80 \mathrm{E}-04$ & 2.44E-05 & $\begin{array}{l}3.04 \mathrm{E}-09 \\
3.51 \mathrm{E}-09\end{array}$ & 8.82E-05 & $2.25 \mathrm{E}-07$ & $5.87 \mathrm{E}-02$ & $5.55 \mathrm{E}-02$ & $1.05 \mathrm{E}-05$ & $1.05 \mathrm{E}-05$ & $1.94 \mathrm{E}-02$ & 1.13E-02 & $6.17 E-08$ & $1.23 \mathrm{E}-08$ & -06 \\
\hline
\end{tabular}




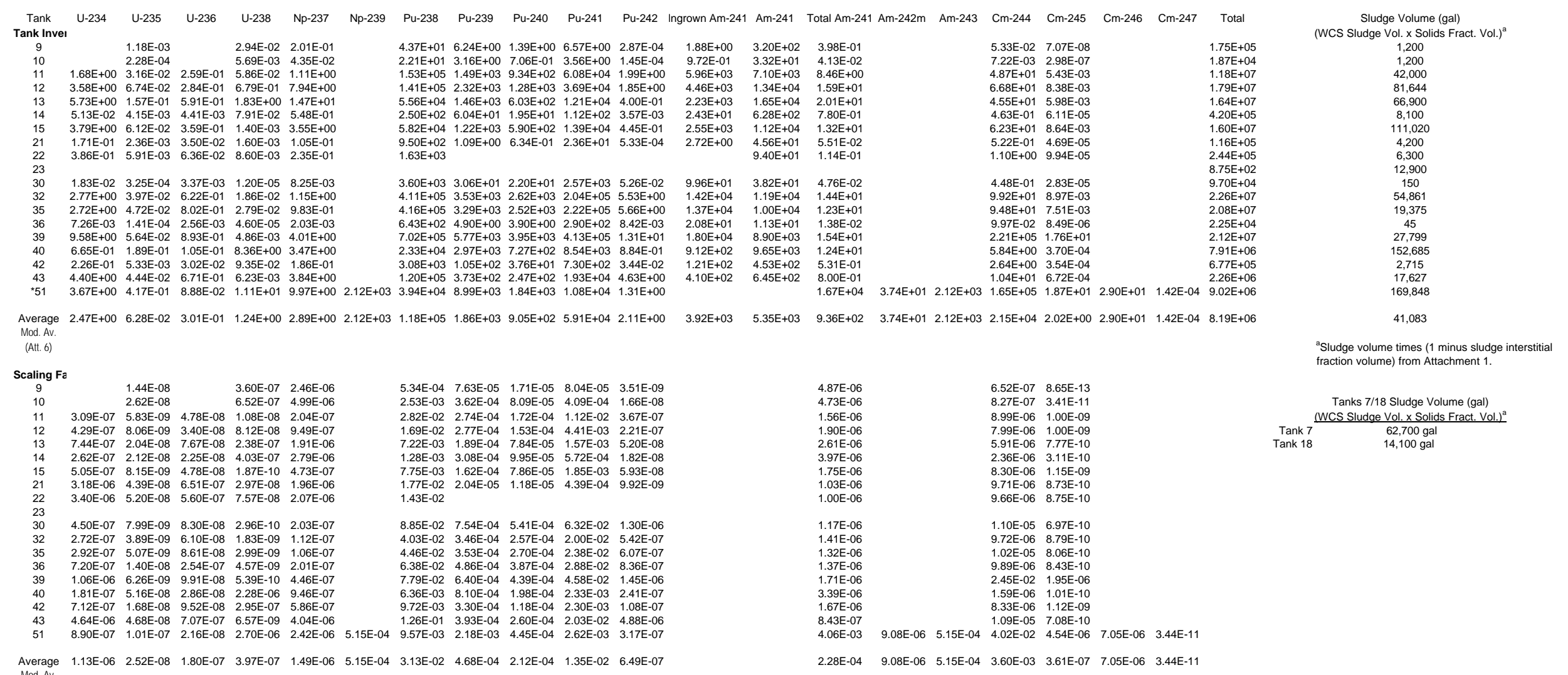


WSRC-TR-2000-00249

Revision 2

Attachment 6

Comparison of H-Area Tank Farm Sludge Scaling Factors and Activity Fractions for Consolidation 
Sludge scaling factors (Ci/Ci Sr-90)

\begin{tabular}{|c|c|c|c|c|c|c|c|c|c|c|c|c|c|c|c|c|c|c|c|c|}
\hline & ank 9 & ank & nk 11 & Tank 12 & Tank 13 & Tank14 & ank 15 & Tank 21 & $\mathrm{~T}$ & 3 & 30 & Tank 32 & Tank 35 & Tank 36 & Tank 39 & Tank 40 & Tank 42 & Tan & Tank 51 & $\begin{array}{l}\text { Mean } \mathrm{Ci} / \\
\mathrm{Ci} \text { Sr-90* }\end{array}$ \\
\hline C-14 & $3.78 \mathrm{E}-08$ & $3.71 \mathrm{E}-08$ & 2.93E-08 & $3.03 \mathrm{E}-08$ & $3.80 \mathrm{E}-08$ & $7.68 \mathrm{E}-09$ & $3.12 \mathrm{E}-08$ & $1.67 \mathrm{E}-09$ & & & $1.92 \mathrm{E}-08$ & $2.40 \mathrm{E}-08$ & $2.22 \mathrm{E}-08$ & \begin{tabular}{|l|l|}
$2.32 \mathrm{E}-08$ \\
\end{tabular} & $2.01 \mathrm{E}-08$ & $1.67 E-07$ & $8.12 \mathrm{E}-08$ & & $3.47 \mathrm{E}-07$ & $5.73 \mathrm{E}-08$ \\
\hline Tc-99 & $5.27 \mathrm{E}-04$ & $5.14 \mathrm{E}-04$ & $2.83 \mathrm{E}-04$ & $3.20 \mathrm{E}-04$ & $3.81 \mathrm{E}-04$ & 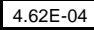 & $3.25 \mathrm{E}-04$ & $2.46 \mathrm{E}-04$ & $2.47 \mathrm{E}-04$ & & $E-04$ & $2.48 \mathrm{E}-04$ & $2.27 \mathrm{E}-04$ & \begin{tabular}{|l|l|}
$2.38 \mathrm{E}-04$ \\
\end{tabular} & $2.05 \mathrm{E}-04$ & .04 & 04 & $E-04$ & -04 & $3.19 \mathrm{E}-04$ \\
\hline $1-129$ & $2.51 \mathrm{E}-09$ & $4 \mathrm{E}-09$ & BE-10 & 1.16E-09 & \begin{tabular}{|l|}
$1.53 \mathrm{E}-09$ \\
\end{tabular} & \begin{tabular}{|l|}
$2.09 \mathrm{E}-09$ \\
\end{tabular} & $\begin{array}{l}1.12 \mathrm{E}-09 \\
\end{array}$ & \begin{tabular}{|l|}
$8.52 \mathrm{E}-10$ \\
\end{tabular} & $8.54 \mathrm{E}-10$ & & $6.79 \mathrm{E}-10$ & \begin{tabular}{|l|}
$8.57 E-10$ \\
\end{tabular} & $7.86 \mathrm{E}-10$ & $22 \mathrm{E}-10$ & $7.09 \mathrm{E}-10$ & $1.74 \mathrm{E}-09$ & 1.1 & $6.91 \mathrm{E}-10$ & -08 & $.04 \mathrm{E}-09$ \\
\hline & $=-09$ & 4E-09 & & & $1.53 \mathrm{E}-09$ & $2.09 \mathrm{E}-09$ & & $8.52 \mathrm{E}-10$ & & & & -10 & -10 & -10 & & & & & & $E-09$ \\
\hline 234 & & & $3.09 \mathrm{E}-07$ & $29 \mathrm{E}-07$ & $7.44 \mathrm{E}-07$ & $2.62 \mathrm{E}-07$ & $5.05 \mathrm{E}-07$ & $18 \mathrm{E}-06$ & $40 \mathrm{E}-06$ & & $4.50 \mathrm{E}-07$ & $2.72 \mathrm{E}-07$ & $2.92 \mathrm{E}-07$ & $7.20 \mathrm{E}-07$ & $6 \mathrm{E}-06$ & $81 \mathrm{E}-07$ & $12 \mathrm{E}-07$ & $64 E-06$ & $8.90 \mathrm{E}-07$ & $.13 \mathrm{E}-06$ \\
\hline & & & & & & & & & & & & & & & & & & & & \\
\hline
\end{tabular}

\begin{tabular}{|c|c|c|c|c|c|c|c|c|c|c|c|c|c|c|c|c|c|c|c|}
\hline \multicolumn{20}{|c|}{ PA radionuclides, fraction of mean scaling factor (allowable fraction $=0.1-10.0$ ) } \\
\hline Isotope & Tank 9 & Tank 10 & Tank 11 & Tank 12 & Tank 13 & Tank14 & Tank 15 & Tank 21 & Tank 22 & Tank 23 & Tank 30 & Tank 32 & Tank 35 & Tank 36 & Tank 39 & Tank 40 & Tank 42 & Tank 43 & Tank 51 \\
\hline C-14 & 0.66 & 0.65 & 0.51 & 0.53 & 0.66 & 0.13 & 0.54 & 0.03 & & & 0.33 & 0.42 & 0.39 & 0.40 & 0.35 & 2.92 & 1.42 & & 6.06 \\
\hline Tc-99 & 1.65 & 1.61 & 0.89 & 1.00 & 1.19 & 1.45 & 1.02 & 0.77 & 0.77 & & 0.62 & 0.78 & 0.71 & 0.74 & 0.64 & 1.17 & 1.00 & 0.63 & 1.36 \\
\hline $\mid-129$ & 0.83 & 0.80 & 0.32 & 0.38 & 0.50 & 0.69 & 0.37 & 0.28 & 0.28 & & 0.22 & 0.28 & 0.26 & 0.27 & 0.23 & 0.57 & 0.37 & 0.23 & 11.11 \\
\hline & 0.72 & 0.70 & 0.28 & 0.33 & 0.44 & 0.60 & 0.32 & 0.24 & 0.24 & & & 0.24 & 0.22 & 0.23 & & 0.50 & 0.32 & & 9.62 \\
\hline $\mathrm{U}-234$ & & & 0.27 & 0.38 & 0.66 & 0.23 & 0.45 & 2.82 & 3.02 & & 0.40 & 0.24 & 0.26 & 0.64 & 0.94 & 0.16 & 0.63 & 4.11 & 0.79 \\
\hline $\mathrm{U}-238$ & 0.91 & 1.65 & 0.03 & 0.20 & 0.60 & 1.02 & 0.0005 & 0.07 & 0.19 & & 0.001 & 0.005 & 0.008 & 0.01 & 0.001 & 5.75 & 0.74 & 0.02 & 6.80 \\
\hline
\end{tabular}

Predominant Radionuclide Fractional activity ([predominant radionuclide $\mathrm{Cij}$ / [total radionuclide $\mathrm{Ci}$ )

\begin{tabular}{|c|c|c|c|c|c|c|c|c|c|c|c|c|c|c|c|c|c|c|c|c|}
\hline \multicolumn{21}{|c|}{ Predominant Radionuclide Fractional activity ([predominant radionuclide $\mathrm{Ci}_{\mathrm{i}}$ / [total radionuclide Ci]) } \\
\hline Isotope & Tank 9 & Tank 10 & Tank 11 & Tank 12 & Tank 13 & Tank14 & Tank 15 & Tank 21 & Tank 22 & Tank 23 & Tank 30 & Tank 32 & Tank 35 & Tank 36 & Tank 39 & Tank 40 & Tank 42 & Tank 43 & Tank 51 & Mean \\
\hline Sr-90 & 4.66E-01 & 4.66E-01 & $4.61 \mathrm{E}-01$ & 4.66E-01 & 4.68E-01 & 4.67E-01 & 4.69E-01 & $4.64 \mathrm{E}-01$ & 4.65E-01 & & 4.19E-01 & $4.52 \mathrm{E}-01$ & 4.48E-01 & 4.47E-01 & 4.25E-01 & 4.64E-01 & $4.68 \mathrm{E}-01$ & 4.20E-01 & $4.57 \mathrm{E}-01$ & 4.55E-01 \\
\hline $\mathrm{Y}-90$ & \begin{tabular}{|l|}
$4.66 \mathrm{E}-01$ \\
\end{tabular} & $4.66 \mathrm{E}-01$ & $4.61 \mathrm{E}-01$ & $4.66 \mathrm{E}-01$ & $4.68 \mathrm{E}-01$ & $4.67 \mathrm{E}-01$ & $4.69 \mathrm{E}-01$ & \begin{tabular}{|l|l|}
$4.64 \mathrm{E}-01$ \\
\end{tabular} & $4.65 \mathrm{E}-01$ & & $4.19 \mathrm{E}-01$ & \begin{tabular}{|l}
$4.52 \mathrm{E}-01$ \\
\end{tabular} & $4.48 \mathrm{E}-01$ & \begin{tabular}{|l}
$4.47 \mathrm{E}-01$ \\
\end{tabular} & $4.25 \mathrm{E}-01$ & $4.64 \mathrm{E}-01$ & $4.68 \mathrm{E}-01$ & $4.20 \mathrm{E}-01$ & \begin{tabular}{|l|l}
$4.57 \mathrm{E}-01$ \\
\end{tabular} & $4.55 \mathrm{E}-01$ \\
\hline
\end{tabular}

\begin{tabular}{|c|c|c|c|c|c|c|c|c|c|c|c|c|c|c|c|c|c|c|c|}
\hline \multicolumn{20}{|c|}{ Predominant radionuclides, variation from mean fractional activity (allowable variation $=100 \%$ ) } \\
\hline Isotope & Tank 9 & Tank 10 & Tank 11 & Tank 12 & Tank 13 & Tank14 & Tank 15 & Tank 21 & Tank 22 & Tank 23 & Tank 30 & Tank 32 & Tank 35 & Tank 36 & Tank 39 & Tank 40 & Tank 42 & Tank 43 & Tank 51 \\
\hline Sr-90 & $2.42 \%$ & $2.33 \%$ & $1.41 \%$ & $2.42 \%$ & $2.82 \%$ & $2.67 \%$ & $3.15 \%$ & $1.89 \%$ & $2.23 \%$ & & $-7.99 \%$ & $-0.75 \%$ & $-1.66 \%$ & $-1.78 \%$ & $-6.70 \%$ & $1.86 \%$ & $2.94 \%$ & $-7.67 \%$ & $0.41 \%$ \\
\hline Y-9 & $2.42 \%$ & $2.33 \%$ & $1.41 \%$ & $2.42 \%$ & $2.82 \%$ & $2.67 \%$ & $3.15 \%$ & $1.89 \%$ & $2.23 \%$ & & $-7.99 \%$ & -0 & -1 & $-1.78 \%$ & $-6.70 \%$ & 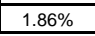 & $2.94 \%$ & $-7.67 \%$ & \\
\hline
\end{tabular}


Revision 2

\section{Attachment 7}

H-Area Tank Farm Sludge Waste Stream Exclusion Criteria 
Attachment 7

\section{H-Area Tank Farm Sludge Waste Stream Exclusion Criteria}

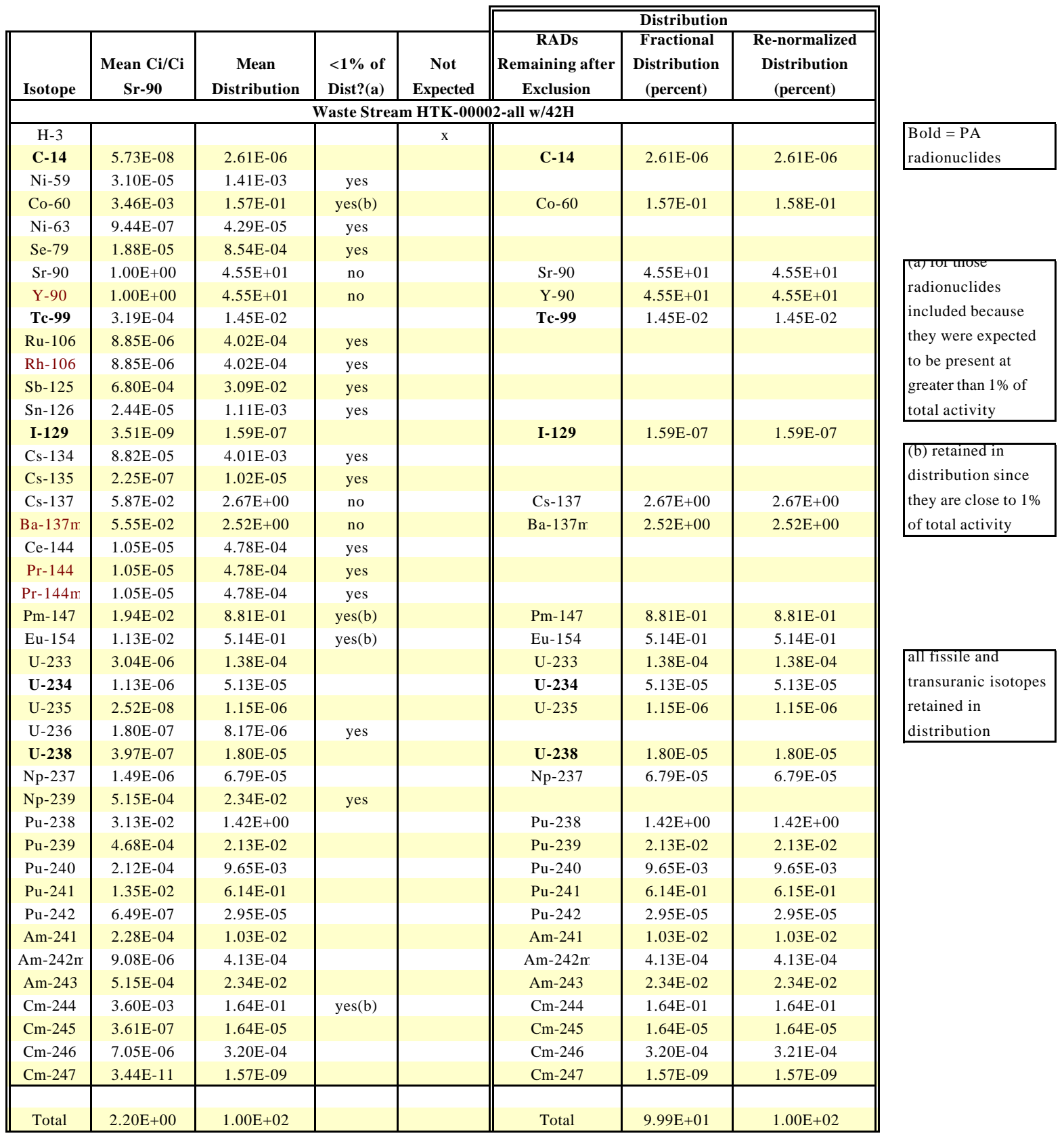


Revision 2

Attachment 8

H-Area Tank Farm Sludge Waste Stream Activity Distribution 


\section{H-Area Tank Farm Sludge Waste Stream Activity Distribution}

\begin{tabular}{|c|c|c|c|}
\hline \multirow[b]{3}{*}{ Radionuclide } & \multicolumn{3}{|c|}{ SLUDGE FRACTION } \\
\hline & $\begin{array}{c}\text { activity } \\
\text { fraction }(\%)\end{array}$ & $\begin{array}{c}\text { normalized } \\
\text { distribution }(\%)\end{array}$ & $\begin{array}{c}\text { scaling factors } \\
\mathrm{Ci} / \mathrm{Ci} \mathrm{Sr}-90\end{array}$ \\
\hline & \multicolumn{3}{|c|}{ Waste Stream HTK-00002 } \\
\hline $\mathrm{H}-3$ & & & \\
\hline C-14 & 2.61E-06 & 2.61E-06 & 5.73E-08 \\
\hline Co-60 & $1.58 \mathrm{E}-01$ & $1.58 \mathrm{E}-01$ & $3.46 \mathrm{E}-03$ \\
\hline Sr-90 & $4.55 \mathrm{E}+01$ & $4.55 \mathrm{E}+01$ & $1.00 \mathrm{E}+00$ \\
\hline Y-90 & $4.55 \mathrm{E}+01$ & $4.55 \mathrm{E}+01$ & $1.00 \mathrm{E}+00$ \\
\hline Tc-99 & $1.45 \mathrm{E}-02$ & $1.45 \mathrm{E}-02$ & 3.19E-04 \\
\hline I-129 & $1.59 \mathrm{E}-07$ & $1.59 \mathrm{E}-07$ & $3.51 \mathrm{E}-09$ \\
\hline Cs-137 & $2.67 \mathrm{E}+00$ & $2.67 \mathrm{E}+00$ & $5.87 \mathrm{E}-02$ \\
\hline Ba-137m & $2.52 \mathrm{E}+00$ & $2.52 \mathrm{E}+00$ & $5.55 \mathrm{E}-02$ \\
\hline Pm-147 & 8.81E-01 & 8.81E-01 & 1.94E-02 \\
\hline Eu-154 & 5.14E-01 & $5.14 \mathrm{E}-01$ & $1.13 \mathrm{E}-02$ \\
\hline U-233 & $1.38 \mathrm{E}-04$ & $1.38 \mathrm{E}-04$ & 3.04E-06 \\
\hline U-234 & 5.13E-05 & 5.13E-05 & $1.13 \mathrm{E}-06$ \\
\hline $\mathrm{U}-235$ & $1.15 \mathrm{E}-06$ & $1.15 \mathrm{E}-06$ & $2.52 \mathrm{E}-08$ \\
\hline U-238 & $1.80 \mathrm{E}-05$ & $1.80 \mathrm{E}-05$ & $3.97 \mathrm{E}-07$ \\
\hline Np-237 & $6.79 \mathrm{E}-05$ & $6.79 \mathrm{E}-05$ & $1.49 \mathrm{E}-06$ \\
\hline $\mathrm{Pu}-238$ & $1.42 \mathrm{E}+00$ & $1.42 \mathrm{E}+00$ & $3.13 \mathrm{E}-02$ \\
\hline $\mathrm{Pu}-239$ & $2.13 \mathrm{E}-02$ & 2.13E-02 & $4.68 \mathrm{E}-04$ \\
\hline $\mathrm{Pu}-240$ & $9.65 \mathrm{E}-03$ & $9.65 \mathrm{E}-03$ & $2.12 \mathrm{E}-04$ \\
\hline $\mathrm{Pu}-241$ & $6.15 \mathrm{E}-01$ & $6.15 \mathrm{E}-01$ & $1.35 \mathrm{E}-02$ \\
\hline $\mathrm{Pu}-242$ & $2.95 \mathrm{E}-05$ & $2.95 \mathrm{E}-05$ & $6.49 \mathrm{E}-07$ \\
\hline Am-241 & $1.03 \mathrm{E}-02$ & $1.03 \mathrm{E}-02$ & 2.28E-04 \\
\hline Am-242m & 4.13E-04 & 4.13E-04 & $9.08 \mathrm{E}-06$ \\
\hline Am-243 & 2.34E-02 & 2.34E-02 & 5.15E-04 \\
\hline $\mathrm{Cm}-244$ & $1.64 \mathrm{E}-01$ & $1.64 \mathrm{E}-01$ & $3.60 \mathrm{E}-03$ \\
\hline $\mathrm{Cm}-245$ & $1.64 \mathrm{E}-05$ & $1.64 \mathrm{E}-05$ & 3.61E-07 \\
\hline $\mathrm{Cm}-246$ & $3.21 \mathrm{E}-04$ & $3.21 \mathrm{E}-04$ & $7.05 \mathrm{E}-06$ \\
\hline$\underline{\mathrm{Cm}-247}$ & $\underline{1.57 \mathrm{E}-09}$ & $\underline{1.57 \mathrm{E}-09}$ & $\underline{3.44 \mathrm{E}-11}$ \\
\hline Total & $1.00 \mathrm{E}+02$ & $1.00 \mathrm{E}+02$ & $2.20 \mathrm{E}+00$ \\
\hline
\end{tabular}


Revision 2

\section{Attachment 9}

Waste Characterization Form for Sludge Fraction, HTK-00002 


\section{EAV Low Level Waste Stream Characterization}

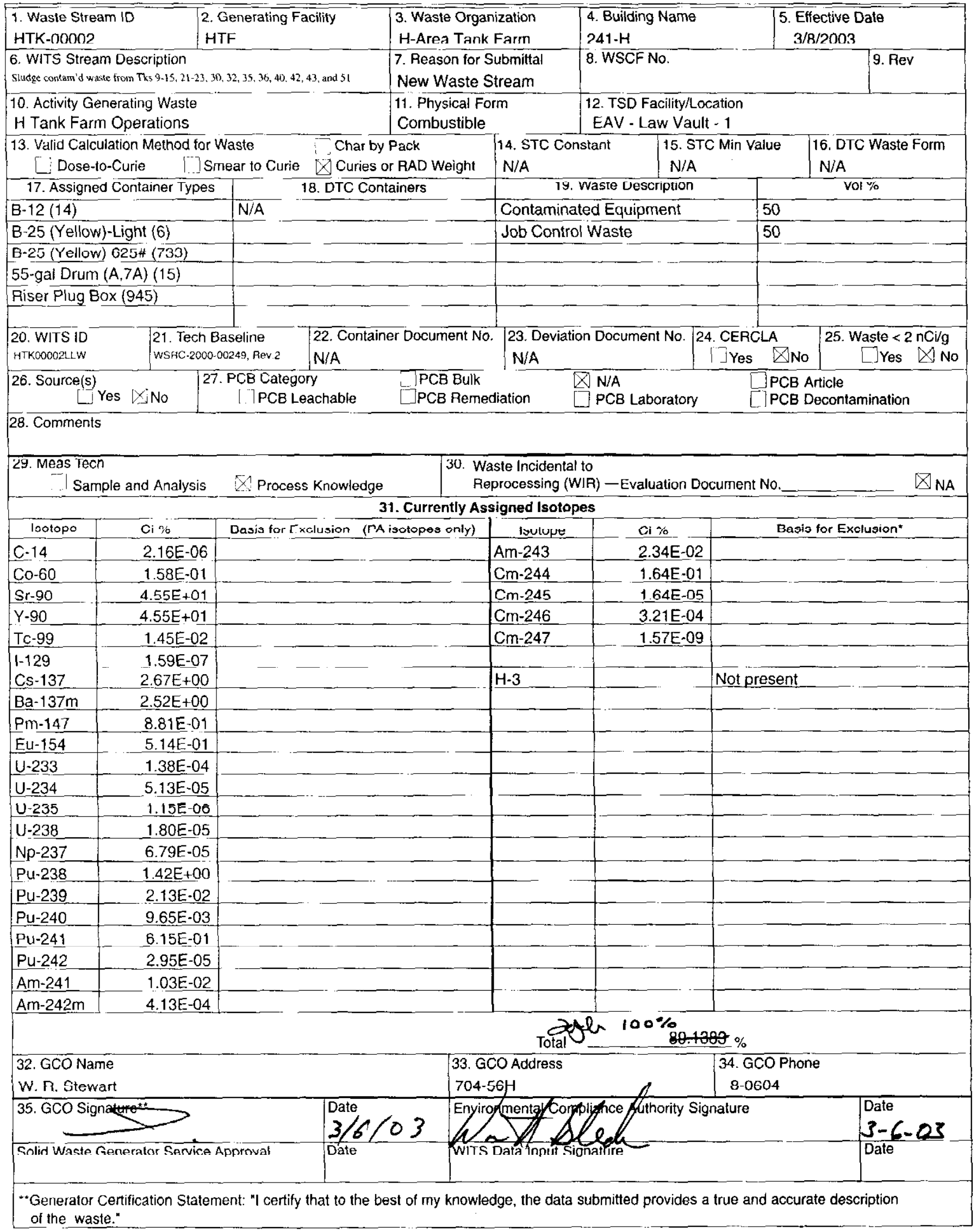


WSRC-TR-2000-00249

Revision 2

\section{Attachment 10}

H-Area Tank Farm Sludge Solids Radionuclide Concentrations 


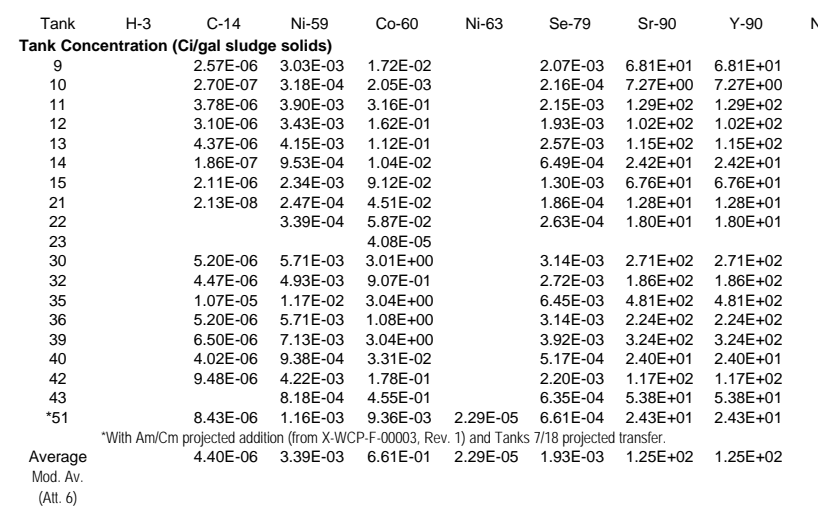

$\begin{array}{llllllllllllllllll}\text { Nb-94 } & \text { TC-99 } & \text { Ru-106 } & \text { Rh-106 } & \text { Sb-125 } & \text { Sn-126 } & \text { l-129 } & \text { Cs-134 } & \text { Cs-135 } & \text { Cs-137 } & \text { Ba-137m } & \text { Ce-144 } & \text { Pr-144 } & \text { Pm-147 } & \text { Eu-154 } & \text { Th-232 } & \text { U-232 } & \text { U-233 }\end{array}$

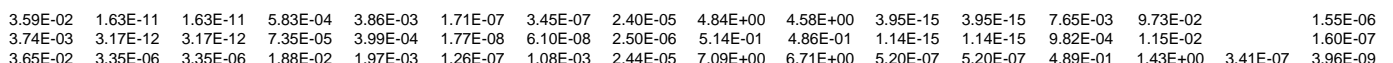

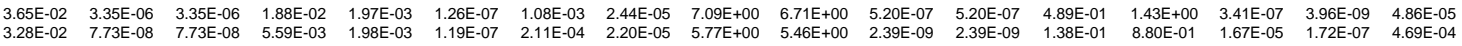

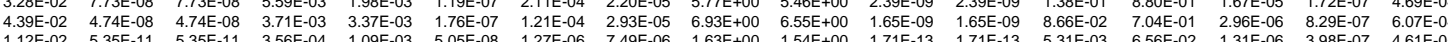

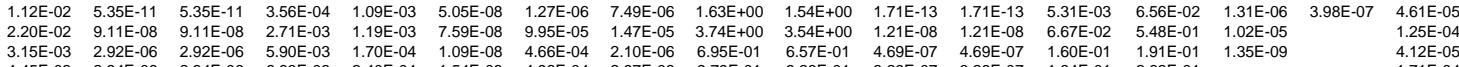

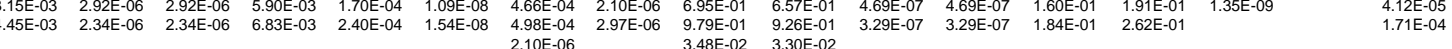

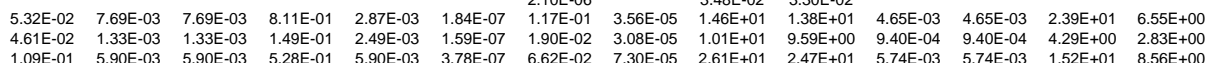

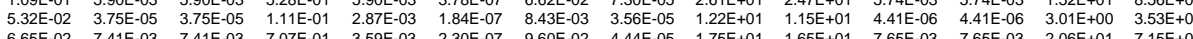

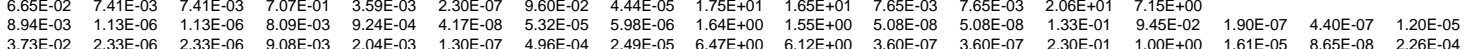

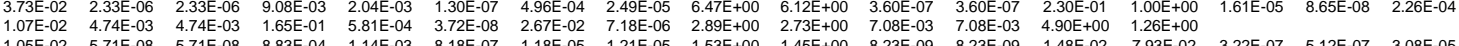

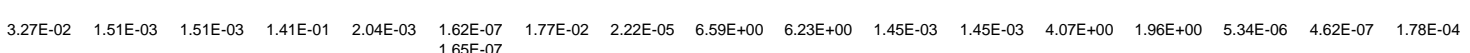




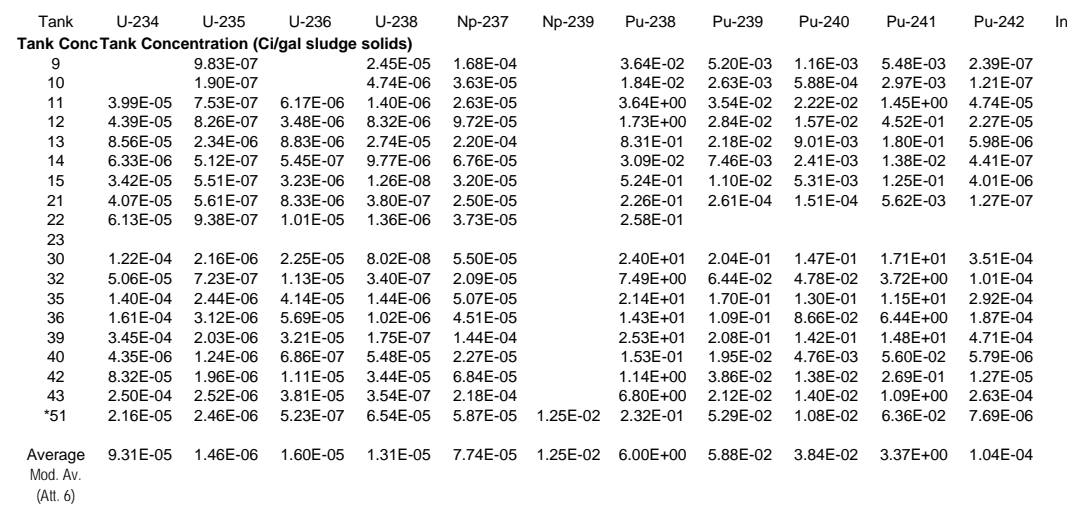

\begin{tabular}{|c|c|c|c|c|c|c|c|c|c|}
\hline Am-241 & Am-241 & Total Am-241 & Am-242m & Am-243 & Cm-244 & $\mathrm{Cm}-245$ & $\mathrm{Cm}-246$ & $\mathrm{Cm}-247$ & Total \\
\hline & $2.67 \mathrm{E}-01$ & $2.68 \mathrm{E}-01$ & $3.31 \mathrm{E}-04$ & & 4.44E- 05 & $5.89 \mathrm{E}-11$ & & & $1.46 \mathrm{E}+02$ \\
\hline $\begin{array}{l}8.10 E-04 \\
142 E-01\end{array}$ & $\begin{array}{l}2.76 E-02 \\
1196-01\end{array}$ & $\begin{array}{l}2.84 E-02 \\
3111-01\end{array}$ & $\begin{array}{l}3.44 E-05 \\
2010-04\end{array}$ & & $\begin{array}{l}6.02 \mathrm{E}-06 \\
1.16-03\end{array}$ & $\begin{array}{l}2.48 \mathrm{E}-10 \\
129-07\end{array}$ & & & $\begin{array}{l}1.56 \mathrm{E}+01 \\
280+02\end{array}$ \\
\hline & & & $\begin{array}{l}2.010-04 \\
1.95 E-04\end{array}$ & & & $\begin{array}{l}1.2 .2 E E-0 / \\
1.03 E-07\end{array}$ & & & \\
\hline 年 & $2.47 \mathrm{E}-01$ & $\begin{array}{l}2.80=-01 \\
2.80-01\end{array}$ & $\begin{array}{l}3.000-04 \\
3.00-04\end{array}$ & & $6.80-54$ & $\begin{array}{l}1.094-18 \\
8.94-08\end{array}$ & & & $2.46 \mathrm{E}+02$ \\
\hline $\begin{array}{l}3.00 E-03 \\
\end{array}$ & $75 \mathrm{E}-02$ & $8.05 \mathrm{E}-02$ & 9.62E-05 & & $5.72 \mathrm{E}-05$ & $7.54 \mathrm{E}-09$ & & & $18 \mathrm{E}+01$ \\
\hline \multirow{3}{*}{$\begin{array}{l}2.30 E-02 \\
6.48 E-04\end{array}$} & $1.01 E-01$ & 1.24E-01 & 1.19E-04 & & $5.61 \mathrm{E}-04$ & $7.79 \mathrm{E}-08$ & & & $44 \mathrm{E}+02$ \\
\hline & $1.09 \mathrm{E}$ & $\begin{array}{l}1.15 E-02 \\
1.49-02\end{array}$ & 1.311 & & 1.24E-04 & & & & $2.76 \mathrm{E}$ \\
\hline & & $\begin{array}{l}1.499-02 \\
0.00 E+00\end{array}$ & & & & & & & 2 \\
\hline $\begin{array}{l}6.645-01 \\
2.59 E-01\end{array}$ & $\begin{array}{l}2.55 \mathrm{E} \\
2.17 \mathrm{E}\end{array}$ & $\begin{array}{l}9.19 \mathrm{E}-01 \\
4.76-01\end{array}$ & $\begin{array}{l}3.17 \mathrm{E} \\
2.62 \mathrm{E}\end{array}$ & & $\begin{array}{l}2.99 E-03 \\
1.18 E-03\end{array}$ & & & & \\
\hline $7.07 \mathrm{C}^{2}$ & & $\begin{array}{l}4.1 .66-01 \\
1.22 E+00\end{array}$ & $6.34 \mathrm{E}$ & & 03 & 3.8 & & & \\
\hline $4.622-01$ & 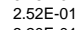 & & $=$ & & $21 E-03$ & & & & \\
\hline $6.47 \mathrm{E}-01$ & & & & & & & & & \\
\hline $\begin{array}{l}5.975-03 \\
4.45-02\end{array}$ & $\begin{array}{l}6.3 .3 E-02 \\
167 E-01\end{array}$ & $\begin{array}{l}\begin{array}{l}6.925-02 \\
2111-01\end{array} \\
2.01\end{array}$ & $\begin{array}{l}8.14-6-05 \\
1.96-04\end{array}$ & & $\begin{array}{l}3.82 E-05 \\
9.73 E-04\end{array}$ & $\begin{array}{l}2.424-09 \\
130=-07\end{array}$ & & & \\
\hline \multirow{2}{*}{$\begin{array}{l}4.45 \mathrm{E}-02 \\
2.33 \mathrm{E}-02\end{array}$} & $\begin{array}{l}3.66 \mathrm{E}-02 \\
3\end{array}$ & 5.98 & 4.54E-05 & & $5.88 \mathrm{E}-04$ & $\begin{array}{l}3.81 \mathrm{E}-08 \\
3.08\end{array}$ & & & $E+02$ \\
\hline & & & 04 & E-02 & $9.74 \mathrm{E}-01$ & $1.10 \mathrm{E}-04$ & & $5 E-10$ & $E+01$ \\
\hline & & & & & & & & & \\
\hline
\end{tabular}

Sludge Volume (gal)

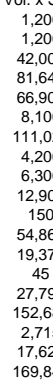

1,200
1,200

$3.20 \mathrm{E}-01 \quad 2.18 \mathrm{E}-04 \quad 1.25 \mathrm{E}-02 \quad 4.96 \mathrm{E}-01 \quad 4.13 \mathrm{E}-05 \quad 1.71 \mathrm{E}-04 \quad 8.35 \mathrm{E}-10 \quad 2.80 \mathrm{E}+02$

fraction volume $x$ (1 1 - sludge interstitial 
Revision 2

\section{Attachment 11}

Comparison of H-Area Tank Farm Sludge Solids Waste Against WAC 3.17, Rev. 7, Requirements 


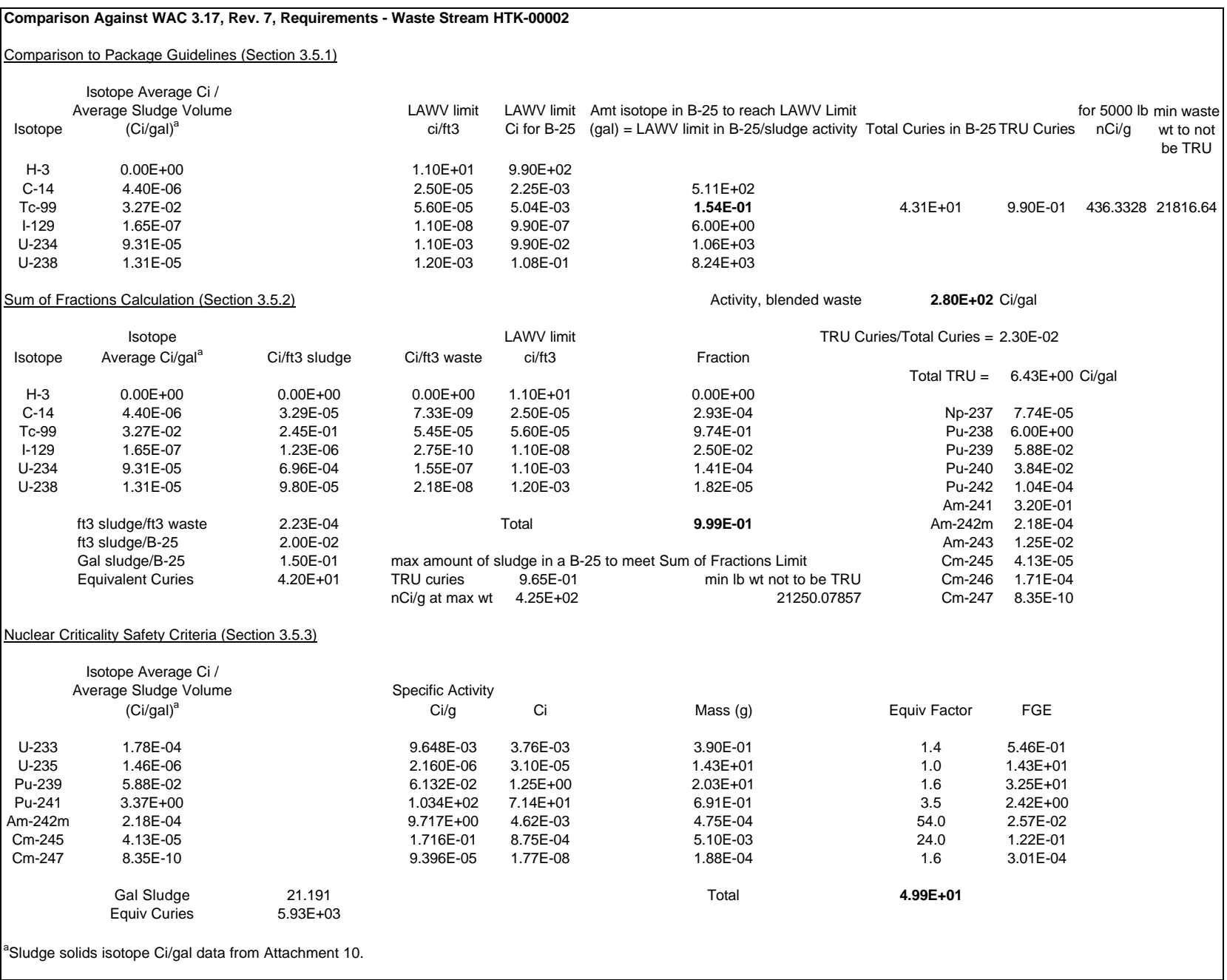

